\title{
The Macroeconomic Aggregates for England, 1209-2008
}

\author{
Gregory Clark, University of California, Davis \\ (gclark@ucdavis.edu)
}

Revised Version - October 2009

UC Davis, Economics WP 09-19

\begin{abstract}
Estimates are developed of the major macroeconomic aggregates - wages, land rents, interest rates, prices, factor shares, sectoral shares in output and employment, and real wages - for England by decade between 1209 and 2008. The efficiency of the economy 1209-2008 is also estimated. One finding is that the growth of real wages in the Industrial Revolution era and beyond was faster than the growth of output per person. Indeed until recently the greatest recipient of modern growth in England has been unskilled workers. The data also creates a number of puzzles, the principle one being the very high levels of output and efficiency estimated for England in the medieval era. This data is thus inconsistent with the general notion that there was a period of Smithian growth between 1300 and 1800 which preceded the Industrial Revolution, as expressed in such recent works as De Vries (2008).
\end{abstract}

\section{Contents}

\section{Introduction}

1. Estimating Economic Growth from Payments to Factors

2. Estimating Economic Efficiency

Wage Income and the Labor Market, 1209-1869

3. Farm Nominal Wages

4. Non-Farm Nominal Wages

5. Share of Labor in Agriculture

6. Average day wage

7. The Wage Premium for Skills

8. Population

9. Days worked per year

10. Aggregate Labor Income

Indirect Taxes, 1209-1869

11. Indirect taxes on property occupiers. 
12. Commodity Taxes

Property Income, 1209-1869

13. Farmland Rental Income

14. Returns on capital

15. Farm capital income

16. Housing rental income

17. Other Property Income

National Income, 1209-1869

18. Nominal National Income and its components

19. Expenditure Prices

20. Export Prices

21. Import Prices

22. Real National Income

23. Cost of Living and Real Wages

Economic Efficiency, 1209-2008

24. Economic Efficiency

25. Output, Factor Shares and Efficiency, 1870-2008 


\section{Estimating Economic Growth from Payments to Factors}

English nominal net domestic income, NDI, is estimated as

NDI $=$ wages + farmland and mineral rents + tithe payments + net mine, canal, road, rail and ship rents + net house rents + other net capital incomes + indirect taxes

Real NDI is NDI deflated by the average price of domestic expenditures, $P_{D E}$. Real net domestic output is NDI deflated by the price of net domestic production, $P_{N D P}$. These two output measures can differ if export and import prices move differently. Dividing by population we get all of these in per capita terms.

\section{Measuring Efficiency, 1209-1869}

The basic measure of the efficiency (total factor productivity) of the economy is an index

$$
A_{t}=\frac{\left(r_{t}+\lambda\right)^{a} p_{K t}{ }^{a} w_{t}^{b} s_{t}^{c}}{p_{t}\left(1-\tau_{t}\right)}
$$

where, $r=$ return on risk free capital, $\lambda$ is a risk premium, $\mathrm{p}_{\mathrm{K}}=$ index of price of capital, $\mathrm{w}=$ index of wages , $\mathrm{s}=$ index of farmland rents, $\mathrm{p}=$ price index, $\tau=$ share of national income collected in indirect taxes.

The price index for outputs, wages, rents are all measured as geometric indexes, with weights changing from year to year. a, b, c are the shares in factor payments of capital, labor and land respectively. These shares are changed every 10 years to reflect changes in the earnings of the different factors over time. Thus though the index has the Cobb-Douglas form the changing weights imply that there is no underlying assumption of a Cobb-Douglas technology. In fact the index is agnostic on the form of the production function, except for an assumption that the capital share is unchanging. 


\section{Wage Income and the Labor Market}

Wages are the most important share of GNI throughout the years 1209-1869, and the most important cost in the index given by (1), with a weight of 50-75 percent. To estimate aggregate wages and labor costs before 1870 the approach here is to first estimate a separate national index of farm day wages, and of non-farm day wages. Then these are aggregated into a national wage using estimates of the structure of occupations, and the relative average wage in the primary sector compared to the rest of the economy. It is shown that for the years 1820-1869 the average national wage estimated on this basis correlates well with a more detailed wage index constructed by Feinstein (1998a, 1998b).

\section{Farm Wage Index}

The details of the construction of the farm day wage index are given in Clark (2007a). The wage estimated is the average day wage of farm workers outside harvest. Farm workers typically earned extra income at hay time and the grain harvest. The average premium at harvest (for 6 weeks) was 61\%, and at hay (for 2 weeks) was 32\%. Assuming a 300 day (50 week) year this implies that the average day wage was $8.6 \%$ greater than the level reported in table 1 . The reported average male farm day wage reflects this adjustment.

The prices and wages reported for the earlier years are frequently dated only by an account year which differs from a calendar year. Thus the most common account year in the medieval period ran from Michaelmas (29 September) to Michaelmas. This was because the harvest was complete only shortly before this quarter feast, and was the natural time for an account to be drawn of the success

of the previous harvest season. Later parish accounts often ran from Lady Day ( $25^{\text {th }}$ March) to Lady Day, or from Easter to Easter, where Easter had no fixed date. In all cases where the exact date of a recorded wage or price is unknown it is attributed to the calendar year in which the majority of the account year falls.

TABLE 1 


\section{Non-Farm Wage Index}

These are estimated as an average of the day wages of skilled and unskilled building workers, as reported in Clark (2005). Again table 1 shows the data by 10 year averages. It is assumed that the ratio of numbers of skilled to unskilled stays the same throughout the years 1209-1869.

\section{Share of Labor Force in the Primary Sector}

For the years 1750-1869 the numbers employed here for employment in the primary sector are those of Shaw-Taylor and Wrigley (2008). Table 2 shows their benchmark estimates for the years $1755,1817,1851$ and 1871. I interpolated between these benchmarks by assuming the same change in employment share in each year between the benchmarks. The assumed share in primary production in the years before 1680 of 0.60 is much less than is assumed in a recent paper by Broadberry, Campbell et. al. (2009), whose assumed shares are shown also in table 2. The reasons for assuming this smaller primary share are two-fold. First for the years 1510-1800 we can get some ancillary information on occupational structure from the stated occupations of a large number of testators. Figure 1 shows the share of these testators who reported primary sector occupations by decade from the 1520 s to the 1860 s, calculated as

$$
s=(1-\varphi) s_{\text {non-London }}+\varphi
$$

where $s_{n o n-\operatorname{London}}$ is the share of testators outside London who list primary sector occupations, and $\varphi$ is the share of the population in London. The share for 1860-9 is 0.21 , close to the numbers reported by Shaw-Taylor and Wrigley. The share for the 1810 s is 0.44 , compared to 0.42 for Shaw-Taylor and Wrigley. The earlier share of primary sector occupations is never as high as the $70 \%$ Broadberry et al. assume for 1600 and earlier. Secondly the structure of the economy will be closely connected to real incomes. We will see below that estimated real incomes in the years 1400-1550 exceed those of 1700-1750, so a much largely primary share for occupations seems unlikely.

\section{TABLE 2}


Figure 1: Share of will makers with primary sector occupations, 1580s-1860s

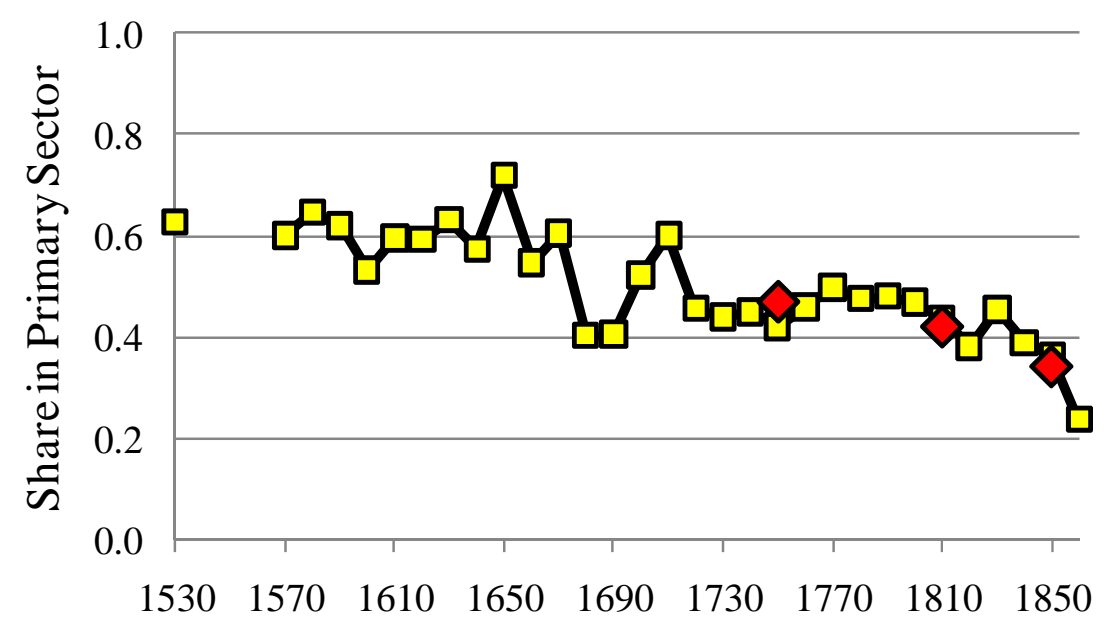

Notes: The variation of the measure in the decades 1640-1729 is due to the small numbers of observations in these years.

\section{Average Implied Day Wage}

To estimate the average day wage in the economy as a whole we need to know what average earnings in the primary sector were compared to the economy as a whole. Leone Levi estimated the average adult male wage in England in 1866 as 45 d. per day (Levi, 1867, 9). The average wage for male farm laborers was, however, only $25.7 \mathrm{~d}$. per day (including an allowance for the harvest premium). However, for each 6 farm workers there was a bailiff or farmer, many of whom worked on their own accounts, and others who supervised hired labor, who would have higher implied labor incomes. For want of better information let us assume that premium was $100 \%$. This implies an average effective implied male wage in the primary sector of $30.0 \mathrm{~d} .^{1}$ The share of employment in the primary sector, mainly agriculture, in the 1860 s was 0.279 . This in turn implies an average male day wage in the rest of the economy of $50.8 \mathrm{~d}$. in 1866, a $69 \%$ premium on average labor income in the primary sector. The average wage in the economy is thus estimated as

\footnotetext{
${ }^{1}$ Coal mining was the other major activity in the primary sector, and was about $10 \%$ of employment in this sector by 1851. In the years 1830-1869 the wage premium for coal miners compared to farm day laborers averaged 63\%. However, making explicit allowance for coal miners and their higher wages in the years 1830-1869 had little effect on the estimated wage trend in the economy 18301869.
} 


$$
\mathrm{W}=\mathrm{b} \omega \sigma \mathrm{W}_{\mathrm{a}}+(1-\mathrm{b}) \sigma\left(\mathrm{W}_{\mathrm{c}}+\mathrm{W}_{1}\right)
$$

where $b$ is the share of labor employed in primary occupations, $W_{a}$ the farm laborer wage, $W_{c}$ the wage of building craftsmen, $\mathrm{W}_{1}$ the wage of building laborers, and adjustment factors of $\omega=1.169$, $\sigma=0.582$, to set the correct average wage levels in each sector. This wage is shown by decade in table 1.

How reasonable is this approximation of (implied) day wage in the economy in years where we have alternative measures? Charles Feinstein constructed such a series for Britain (England, Scotland and Wales) for 1770 on, using wages from a variety of sectors (Feinstein, 1998a, 1998b). Figure 2 shows the respective estimates of the average wage for the years 1770-1869, where the two estimates are set to equality in 1860-9. The present average wage income series rises 9\% more between 1770-9 and 1860-9 than the Feinstein series. But after 1820 the movement of the two series is very similar. Indeed for those years the $\mathrm{R}^{2}$ when we predict one series from the other is 0.92. The major differences between the two series arise in the years 1795-1815. This arises largely from the very different wage series for agriculture that is derived in Clark (2001), than the older Bowley series used by Feinstein. As figure 3 shows these two series diverge wildly in these years. Clark (2001) explains why this new series is to be preferred. Feinstein himself noted of the Bowley series on which he relies in these years.

the most worrying feature of this series is the absence of a reliable benchmark between 1795 and 1824. During these years the index first climbs by some $56 \%$...then falls sharply... These large movements are entirely dependent on Bowley's interpolation on the basis of very limited information (Feinstein, 1998b, 187).

Having derived this wage index, total implied labor income in England in 1866 is estimated from Levi (1867) as in table 3, at $£ 420$ million. This is substantially larger than the implied English wages total for England from Feinstein (1972), table 1 of $f^{298} \mathrm{~m}$. However this amount includes an allowance for the labor income of the self employed which is included by Feinstein along with profits up until 1889. When Feinstein first separates these figures in 1889 total labor income is 44\% greater than income from employment. Applying this adjustment to the 1860s, Feinstein's $\AA^{298} \mathrm{~m}$. of employment income would translate into a total of $£ 428 \mathrm{~m}$. of all labor income, which is very similar to the number calculated here.

TABLE 3 
Figure 2: Estimated Average Day Wages, 1770-1869

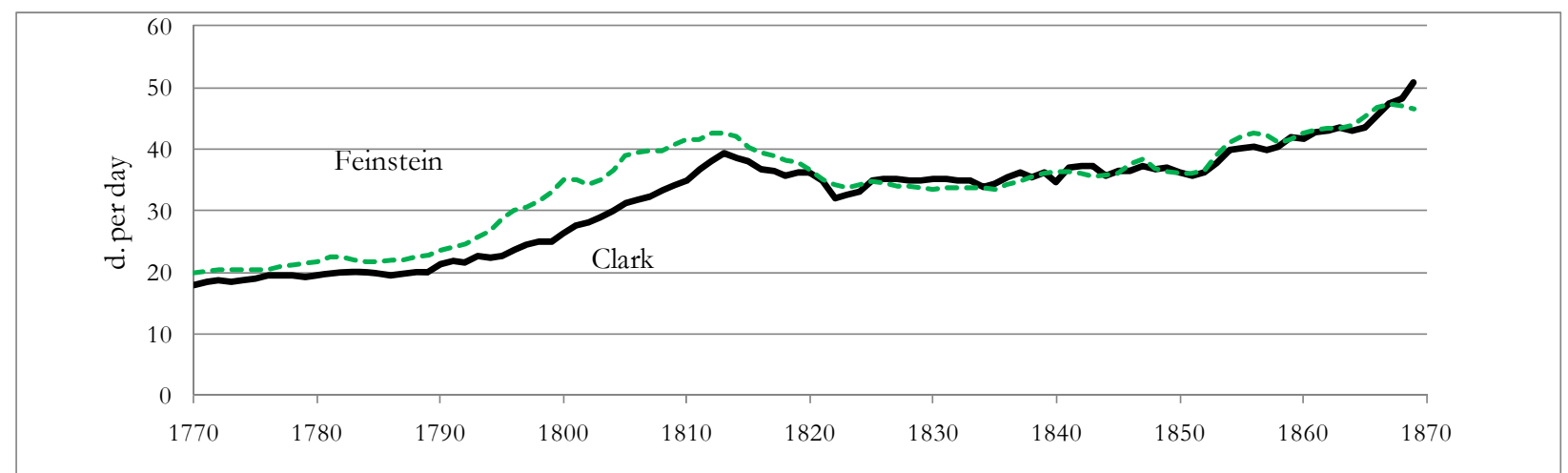

Figure 3: Wages in English Agriculture, 1770-1850

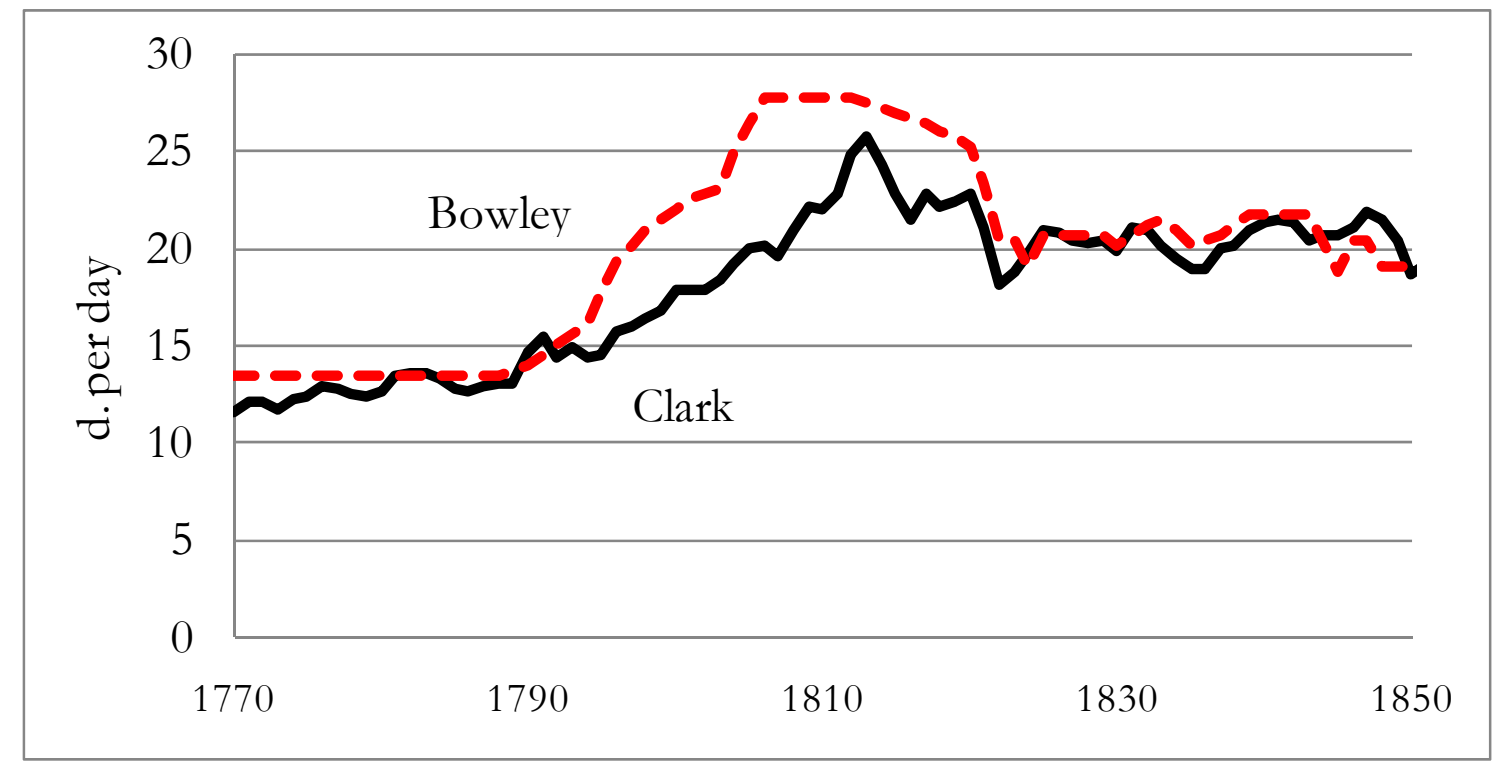

Sources: Bowley (1898), Clark (2001). 


\section{Skill Premium}

The last column of table 1 shows the skill premium, which is measured here by the relative wage of skilled building workers compared to building laborers.

\section{Population and labor supply}

The population before 1540 is estimated as in Clark (2007a). Since this gives decadal estimates the other years are interpolated geometrically, except in the periods 1310-19 and 1340-49 where the timing of the shocks to population in those decades is known. Thus population is assumed to have fallen to the 1320s level by 1318, and to the 1350s level by 1349. The population after 1540 is estimated from Wrigley et al. $(1997,614)$ to 1805 . Thereafter the census totals for England including Monmouth are used, interpolating between the census dates. These estimates by decade are shown as the last column in table 1.

These population numbers for the years before 1500 are controversial. Whereas these estimates imply a population for England c. 1300 of 5.3 million, Bruce Campbell has argued for a much lower population of only 4.25 million. Table 4 shows the population assumed here versus that of Broadberry, Campbell et al. As can be seen for the years 1520 and earlier the estimates here are of a consistently higher population by a margin of 17-30\%. Clark (2007b) explains and defends these population estimates.

\section{TABLE 4}

\section{Days Worked per Year}

This is a very difficult issue. There is widespread belief that the numbers of days per year worked by the population increased greatly between 1200 and 1800, but surprisingly little direct evidence of any substantial increase in work days over this interval (Clark and Van der Werf, 1998; de Vries, 1994, 2008; Voth, 2001a, 2001b). Despite the lack of direct evidence of much change in days worked per year Broadberry, Campbell et al. assume widely varying days worked per farm family over the years 1250-1850, as is shown in table 5. They assume an "industrious revolution" in the years 1700-1850, with a one third increase in days worked per farm family. But they also assume a "de-industrious revolution" in the years 1300-1450, when work days are assumed to decline by nearly 30\%. Thus assumed work days per year per farm family are double in 1850 what they are in 1450. The reason they make the assumptions about work days per year is in order to reconcile their 
estimates of farm outputs directly with estimates of farm output from factor payments (wages, land rents, etc.). Farm wages are so high in 1450, for example, that the total farm output implied if all workers were fully employed would greatly exceed the directly estimated output. This mismatch, however, in part stems from the very high assumed farm share of employment that the authors adopt for the years before 1700 .

\section{TABLE 5}

If there was a rise in work hours per person in England in the years 1650-1800, we would think that it would be possible to demonstrate it in data from the labor market. However, the evidence here for England, even for male workers, the easiest to observe, is at best ambiguous. At worst it suggests no significant increase in work hours for adult males between even 1250 and 1800 .

Clark and van der Werf (1998), for example, find evidence for only a very modest rise in days worked per year by men in the years 1560-1860. If workers were employed by the year and by the day, the days per year of the annual workers should be,

$$
\text { days peryear = annual wage/day wage. }
$$

Complicating factors, such as that yearly workers have more security and might thus accept a lower daily wage, will affect the exact ratio here. Or again annual workers may be better workers and so get a higher daily wage. ${ }^{2}$ But as long as the selection process is the same over time we can use these payment ratios to look at relative days worked per year over time. Table 6 shows this calculation of the typical number of days in the work year as the ratio between the annual payment of workers compared to the day wage of similar workers. Since the table is based on small samples of workers paid in both ways, the standard error of the error is also estimated. The true number of work days will lie within two times the standard error of the estimate given 95 percent of the time.

\section{TABLE 6}

The implied work year for farm workers in the 1870s was 280-311. Back in 1560-99 it was only 257. So the best estimate is of a 10-15 percent increase in work days over this interval. This exercise suggests at best modest increases in days per year between 1560 and 1800 . Other measures of likely

\footnotetext{
2. Alternately, employers may pay less per day for annual workers than for day workers because they then have commitments to use workers for a longer period.
} 
days per year suggest there may have been no increase. We can, for example, calculate at least the common language interpretation of the number of work days in a week in a similar way to days per year. This is by looking at the ratio of the weekly wages quoted for building workers to their daily wage. When a worker was hired for a "week" what did that mean? Figure 4 shows the results of this calculation for English 290 wage quotes for building workers in the decades 1250-1620, prior to de Vries's Industrious Revolution. There is no trend. And the notional work week is just as long in 1250 as in 1850: it averages 5.97 days. This does not preclude workers more often working broken or shortened weeks in the earlier years - the records of the construction of Exeter Cathedral in the middle ages show many such interruptions. ${ }^{3}$ But it does show there was no standard pattern of shorter work weeks in the earlier society.

For these reasons the estimates here are constructed using an assumption of a constant 300 day work year for men between 1209 and 1869. One way to interpret this is to say that it is giving a measure of the potential NDI of the English economy over these years. If leisure has a value, and that value is close to the daily wage, then even if workers voluntarily took more holidays earlier, this measure shows what the relative living standards were across time. This assumption about wording days per year will not affect the estimates of income from land or house ownership. It will, however, affect the estimates of income from working capital in earlier years because of the ways that is calculated.

\section{Aggregate (Potential) Labor Income}

Aggregate (potential) labor income is calculated as

$$
\mathrm{W}_{\mathrm{AG}}=\mathrm{W} \times 300 \times(\mathrm{vN}) \text {, }
$$

where $\mathrm{W}$ is the average male day wage, $\mathrm{N}$ the population, and $\nu$ the fraction of the population economically active measured in male-equivalents (assumed to be 0.340). These numbers are shown in table 7 (by decade). The numbers are set to match the implied total of Leone Levi for the 1860s, with a labor income for this decade of $f, 420.8 \mathrm{~m}$. This implies a total labor income significantly greater than that estimated by Deane and Cole $(1967,152)$, who give a labor income for Britain in

\footnotetext{
${ }^{3}$ Voth, 2001a, interprets the Exeter Cathedral accounts as suggesting medieval workers put in many few days per year. But on the days when they were not at work on the Cathedral they may have been engaged elsewhere. If you had used the records of my house remodel to measure the number of days worked by workers in the modern world, you would have concluded that workers put in less than 100 days per year.
} 
Figure 4: Implied length of the "week" for building workers in England, 1250-1629

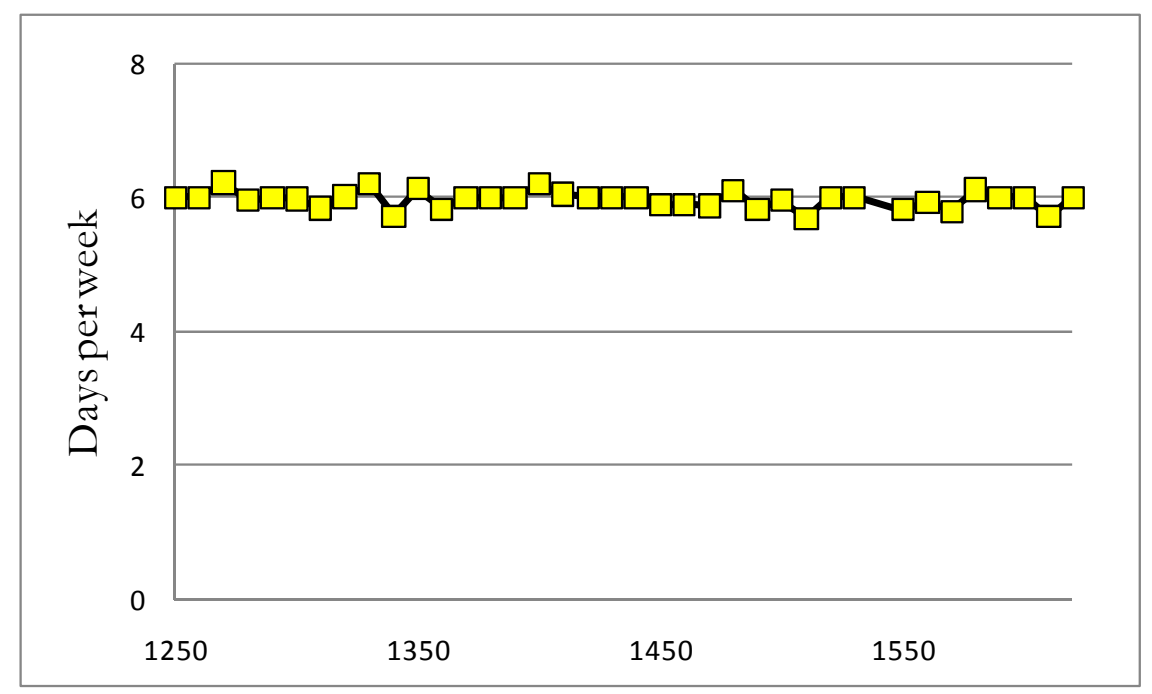

1861 of only $£ 315.4 \mathrm{~m}$., and for 1871 of $£ 408.4 \mathrm{~m}$. (implying for the $1860 \mathrm{~s}$ an English total labor income of $f_{2} 265-343 \mathrm{~m}$.). ${ }^{4}$ But Deane and Cole have another category of income "profits, interest and mixed incomes" which includes income from self-employment which is functionally the same as wages. This category is $39 \%$ of all income in the $1860 \mathrm{~s} \mathrm{(p.} \mathrm{247).} \mathrm{Here} \mathrm{I} \mathrm{have} \mathrm{attributed} \mathrm{an} \mathrm{estimated}$ wage income to all the occupied population.

\section{TABLE 7}

\section{Indirect Taxes}

Before I calculate the income from working capital and entrepreneurial returns, I need to calculate the income derived by government from indirect taxes.

\section{Indirect taxes on property occupiers.}

One form of taxation in England was that on the occupiers, as opposed to the owners, of property. These were the various local rates - poor rates, county rates, road rates, church rates, constable rates - which because of the dominance of poor rates were often referred to just as the "poor rate." Because these taxes were paid by occupiers as opposed to owners they do not appear

${ }^{4}$ Feinstein, 1972, T4, also gives labor income for the UK in the 1860s that implies much lower levels for England than calculated here. But he also has "mixed incomes" that include some labor income. 
above under land rent and tithes, though their incidence probably lay mainly on the rental value of land and houses.

There are totals of such rates for England and Wales in the years 1747-9, 1775, 1782-4, 1802, 1812-69 (Mitchell, 1962, 410-11). These are converted to an English basis by multiplying by the share of the population English in 1801 (0.94). To estimate poor rate payments in other years data was collected from the parish accounts of 33 parishes in Bedford, Dorset, Essex, Warwick, over the years 1577-1869. Payments in each parish relative to the years 1824-33 were calculated for each year with data. An average (weighted by the size of payments 1824-33) was then calculated for each year. Payments on this index are shown by ten year averages in table 7 . Before 1600 the amounts of these taxes was modest, and they are assumed 0 for the years before 1570 when there are no records of their size.

Later I also need to calculate what share of these taxes was paid from farmland. In 1832 poor rates per head were about double in parishes with all the employment in agriculture than they were in parishes where none of the employment was agricultural. I thus assume throughout all these years that this differential was the same. Then I calculate the share of poor rates paid by the farming sector as

$$
\text { Share poor rates from farmland }=\frac{2 \theta}{1+\theta}
$$

where $\theta$ is the share of the population employed in farming. This would imply that if $\theta=0.5$, the share paid by the farming sector would be 0.67 .

\section{Commodity Taxes}

In the eighteenth century indirect taxes on commodities became an important source of government income in England. Under the pressures of war finance demands the government introduced significant taxation of many commodities - beer, wine, candles, bricks, paper, etc. The revenue from these indirect taxes - customs dues, excise taxes - is reported for the UK 1801-1869, for Great Britain1689-1800 and 1807-1816, for England and Wales, 1660-1688 (Mitchell, 1962, 3868, 392-3). UK figures are reduced to those for Great Britain by multiplying by 0.92 their relative share in 1807-16. Totals for Great Britain are reduced to those for England alone by multiplying them by 0.84 , based on the population of England relative to Great Britain in 1801. Before 1551 indirect taxes are taken as $0 \%$ of national income, since in the years 1551-57 they averaged only $0.2 \%$ of national income. Table 7 shows decadal totals for indirect taxes. 


\section{Property Income}

To get the total gross value of income in the economy we need to add to wage income the returns from ownership of property: land, houses, shops, industrial buildings, roads, canals, waterways, mines, machines, and working capital such as farm animals and horses. After 1842 we have information on such returns from the Property and Income Tax Returns. These returns distinguish income from property of the following types: lands, houses, tithes, manors, fines, quarries, mines, iron works, fisheries, canals, and railways. For the 1860s the average of these reported incomes, reduced to the basis of England, was as follows:

Farmland and farm buildings (including tithe)

Other houses and buildings

Profits from land occupation

Profits of Mines, Canals, Railways, etc.

Other business and professional incomes
$£ 46.0 \mathrm{~m}$.

£60.3 m.

$£ 23.0 \mathrm{~m} .^{5}$

$£ 21.0 \mathrm{~m}$.

f84.4 m. ${ }^{6}$

The tax returns thus do not give any real estimate of property income in agriculture. Also business and professional incomes exclude some incomes under $£ 100$ which were earlier exempt from tax, and this exemption limit was lifted to $£ 150$ in 1853. For those with incomes of $£ 100$ or less in business or a profession the majority would likely actually be wage income (in the 1860s the annual earnings of a building craftsman would be f(66). Thus the tax reports of business and professional incomes includes wage income for small proprietors and professionals. Here I take as property income all business and professional income of $£ 150$ or greater 1842-1869. It is assumed here that the exclusions of the property incomes with those with gross incomes under $£ 150$ cancel out the inclusion of wage income for those with income of $£, 150$ or more. The proportions of each class in 1855-6 in England among reported incomes were

Less than $£ 100 \quad £ 5.9 \mathrm{~m}$

$£ 100-£ 150 \quad £ 10.6 \mathrm{~m}$

More than $£ 150$

f.49.4 $\mathrm{m}^{7}$

\footnotetext{
${ }^{5}$ This was assessed as $1 / 2$ of land rental values (Stamp, 1922, 82).

${ }^{6}$ Counting only such incomes $£, 150$ or greater. See below.

${ }^{7}$ Stamp, 1922, 511.
} 
But there is reason to believe that there may be underreporting of the "less than $f_{100 "}$ income group who were not liable for the income tax.

The tax returns report the gross income from farmland and housing and other buildings. For business incomes the 1842 Tax Acts allowed deductions for sums expended in "for the repairs of premises and the supply or repair of alterations of any implements" (Stamp, 1922, 178). Thus business and professional income was effectively assessed as net income.

\section{Farmland Rental Income}

Land rents are estimated from the market rental values, including tithes and land taxes that fell on occupiers, of plots of unchanging area over the years 1209-1869. The rent paid to the owner of land was only one claim on the site value of the land. In addition there was the tithe due originally to the church, but later to private owners of tithe rights. This was nominally 10 percent of the gross output of the land but was later collected at typically much lower rates. Also increasingly from 1600 on there were local parish levies to support the poor, and pay for the roads and other services. By the nineteenth century were 6-10 percent of the rents paid by occupiers.

The rent series used here gives the rental value of farmland inclusive of the tithe, but not including taxes paid by occupiers which are enumerated separately. The details of how this was constructed for the later years are discussed in Clark (2002a). This series thus includes imputed rents in the case where owners were also occupiers. Much land was bundled with dwellings, and the land rents measured here thus include payments for farmhouses and farm buildings.

To avoid problems of land quality and varying land measures the series is constructed by looking at what happens to the same plot over time, except in the medieval period where the less rigorous measure of the same type of land in the same village is used. The rent series thus incorporates and values in earlier years communal "waste" land only later brought into private cultivation. It is assumed throughout that there were $28.24 \mathrm{~m}$. acres of farmland in England, though in earlier years some of this would be uncultivated waste. From 1842 on these rental values are estimated from Income and Property tax returns (Stamp, 1922, 49). Tables 7 and A2 shows the value for England of these imputed land rents.

It is also assumed that land rents represented rents net of repairs to fences, ditches and buildings, which are assumed to be made by the tenants. 


\section{Returns to capital}

For England evidence on interest rates goes back to about 1170. Figure 5 shows the rate of return on two very low risk investments in England from 1170 to 1900. The first is the gross return on investments in agricultural land, $R / P$, where $R$ is the rental and $P$ the price of land. This can differ from the real return on land,

$$
r=\frac{R}{P}+\left(\pi_{L}-\pi\right)
$$

where $\pi_{L}$ is the rate of increase of land prices and $\pi$ is the general rate of inflation. $\left(\pi_{L}-\pi\right)$ is the rate of increase of real land values. But the rate of increase in real land values in the long run has to be low in all societies, and certainly was low in pre-industrial England. If the rate of increase of real land prices was as high as $1 \%$ per year from 1300 to 1800, for example, it would increase the real value of land by 144 times over this period. Thus the rent/price ratio of land will generally give a good approximation to the real interest rate in the long run.

The second rate of return is that for "rent charges." Rent charges were perpetual fixed nominal obligations secured by land or houses. The ratio of the sum paid per year to the price of such a rent charge gives the interest rate for another very low risk asset, since the charge was typically much less than the rental value of the land or house. The major risk in buying a rent charge would be that since it is an obligation fixed in nominal terms, if there is inflation the buyer gets a lower real rate of return. Again the gross rate of return shown is $R / P$, where $R=$ annual payment, $P=$ price of rent charge. The real rate of return, $r$, in this case is

$$
r=\frac{R}{P}-\pi
$$

Table 8 shows the assumed risk-free return on capital by decade 1200-1869, taken as the average of these two rates.

TABLE 8 
Figure 5: The Return on Land and on Rent Charges, 1170-2003 (by decade)

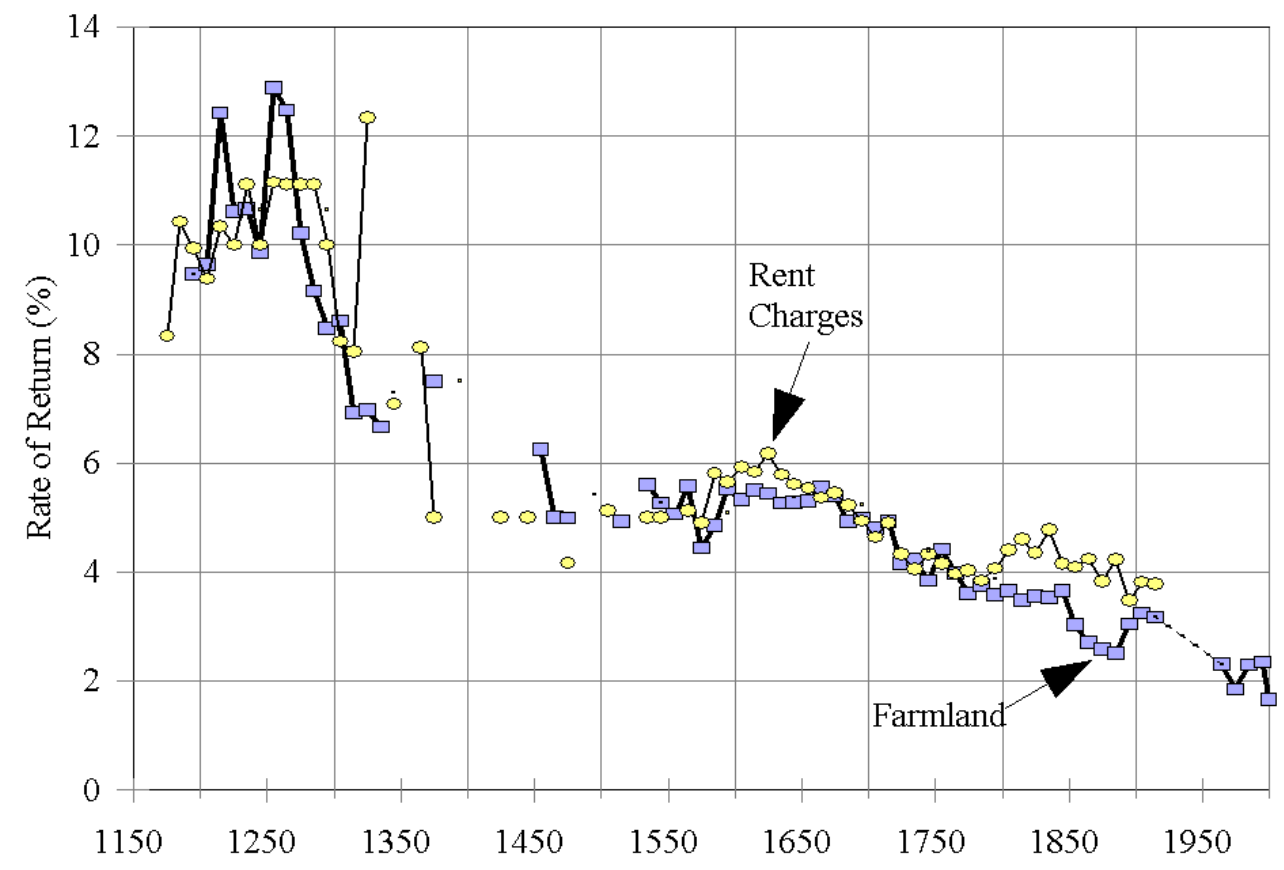

Notes: For the years before 1350 the land returns are the moving average of 3 decades because in these early years this measure is very noisy.

\section{Farm Working Capital Income}

There are various estimates on the value of the capital supplied by the tenant per acre of land in England in the nineteenth century, with general agreement on the rough magnitudes involved. The most detailed, by Charles Wratislaw in 1861, and the one I use as a benchmark, suggests that the tenant needed to supply on average $f^{8} 8.68$ per acre. Other estimates from 1838 and 1878 suggest respectively $£, 10$ and $£, 12$ per acre. ${ }^{8}$ Wratislaw omits any allowance for the cost of the maintenance of the farmer over the course of the year. Assuming the farmer expends $£ 100$ on himself, Wratislaw's capital per acre would be $f^{9} 9.2$. This would be composed as follows

\footnotetext{
${ }^{8}$ Wratislaw (1861), Tomson (1847), Squarey (1878).
} 
Live Stock $\quad 60 \%$

Implements $\quad 11 \%$

Seed, Labor, Horse and Cattle Food $\quad 21 \%$

Rent, tithe and taxes in advance $\quad 3 \%$

Maintenance of farmer $\quad 5 \%$

Allowing the farmer just the return on capital from bonds or mortgages, this would imply a capital cost in the 1860 s of $f^{0.39}$ per acre. However, as with all business enterprises their has to be an additional return based on the risk of the enterprise. Farming was not a high return activity so I set this additional return at 3\%. This raises the working capital return per acre to $£_{0} 0.69$. The land rent actually includes a substantial amount that is a return to capital in the form of buildings and land improvement. Conventionally the farmers profit was expected to be half the rental of the land before 1896 (Stamp, 1922, 82), though this return included the farmer's wage which I have included elsewhere. With a land rental in the $1860 \mathrm{~s}$ of $£ 46 \mathrm{~m}$, that would imply a profit income of $£^{23} \mathrm{~m}$. The net profit income on working capital calculated here for the $1860 \mathrm{~s}$ is $f 19 \mathrm{~m}$.

To estimate the equivalent capital costs for the other decades I make the following assumptions. First that the interest cost of the capital employed by farmers was the average of the return on rent charges and land, plus 3\% for risk. Second that the price of capital goods was the same as the price of farm output. Since live stock, seeds, and animal food were the majority of the capital stock, and implements were a small share, this assumption seems reasonably innocuous. Lastly I assume that the capital-output ratio for the farmer's capital did not change over time. This last assumption is the most contentious. But again when we consider the importance of animals, fodder and seeds in farmer's capital it does not seem that there was any reason to expect any change in the capital output ratio over time. With these assumptions I get the implied payments for working capital in agriculture shown in table 8.

In table 8 the payments to capital in year t are calculated, using these assumptions, as

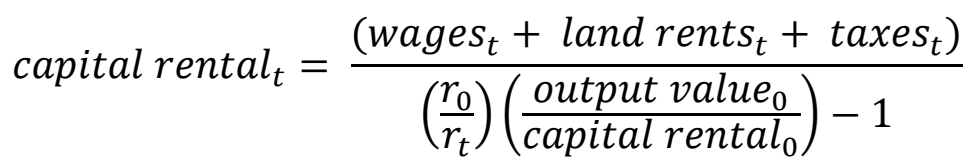

where $\mathrm{r}_{0}=$ return on capital in the $1860 \mathrm{~s}, \mathrm{r}_{1}=$ return on capital in year t. ${ }^{9}$

${ }^{9}$ This follows from the fact that, by assumption 
Now that we have estimates of farm wages, land rents, poor rates paid by land occupiers, and farm working capital returns I can also estimate the total output of the agricultural sector. This is shown in table 8.

\section{Rental value of housing and other structures}

To estimate this I start with a measure of the average rental value of a "dwelling" in England. This measure is calculated separately for London and the rest of England because of the much greater value of property in London throughout these years. This requires estimating the share of the population in London and the rest of England throughout these years. "Dwelling" is set in quotes because dwelling were intermixed with shops, pubs, malthouses, barns etc. in all these years

To get total rentals of all non-farm structures in the economy, I calculate from the property tax returns the total value of these rentals 1842-1869 (Stamp, 1922, 50). I project this back before 1842 by estimating the numbers of non-farm dwellings in each decade, and the average rental value of dwellings over time from the 1260 s to the 1860 s. The method used here is described in Clark (2002b). There are 14,261 observations on the prices or rent of dwellings in London and elsewhere for the years 1265-1869, 4,272 from before the year 1800. But there are relatively few observations for the years before 1500, 659 only, so that the index is noisy in the earliest years. To get the total implied rental value of dwellings I need an estimate of the number of non-farm dwellings. In 1801 and later the censuses give the average number of people per dwelling. For earlier years I assume the average number of people per dwelling is the same as in 1801, 5.44. As noted when discussing land rents, farmhouses and farm buildings are already accounted for under the rental value of farmland. I assume throughout all these years that there were 250,000 farmhouses whose rent was already accounted for under land rents throughout the years 1209-1869, based on the number of farmers reported for England in the 1860s. This implies that in the decade where England's

$$
\begin{aligned}
& \Rightarrow\left(r_{t}+d\right) K_{t}=\left(r_{0}+d\right) K_{0} \frac{\left(r_{t}+d\right)}{\left(r_{0}+d\right)} \frac{Q_{t}}{Q_{0}} \frac{K_{t}}{K_{0}}=\frac{Q_{t}}{Q_{0}} \\
& \Rightarrow\left(r_{t}+d\right) K_{t}=\frac{\left(r_{0}+d\right) K_{0} \frac{\left(r_{t}+d\right) \text { wages }_{t}+r_{0}+r_{0}+\text { taxes }_{t}}{\left(r_{0}+d\right)}}{1-\left(r_{0}+d\right) K_{0} \frac{\left(r_{t}+d\right) 1}{\left(r_{0}+d\right) Q_{0}}}
\end{aligned}
$$


population was estimated to be at its lowest, the 1440 s with only 2.27 million people, aside from an assumed 250,000 farmhouses there were only 168,000 other dwellings.

The implied rental income reported here is a gross rental. Thus to get the net rental income we need to deduct repairs. Clark (1998a) calculates the return on land and housing in England by quinquennia for the eighteenth and nineteenth centuries. The returns on housing average about $2 \%$ more than those on land, suggesting that the depreciation rate for housing is about $2 \%$. To get the net rental of housing I deduct for each period a fraction of the estimated rental which is:

$$
\frac{2}{r+2}
$$

where $\mathrm{r}$ is the return on land (in percent). The total net rental is shown in table 8 also.

\section{Other Property Incomes}

The Property Tax returns for the years 1842 and later distinguish property incomes from quarries, coal mines, canals, railways and iron works (Stamp, 1922, 220). These reported sums are for Great Britain for the years 1842-1853, and the UK thereafter. To convert them to an English basis I assume, unless otherwise indicated, that England was $84 \%$ of British economic activity and that after 1853 there was no income in Ireland from quarries, coal mines, ironworks, canals, railways and gasworks (there would be some income but it assumed to be negligibly small). These returns do not include, however, the imputed income from capital invested in roadways. These property incomes are in each case carried back to 1730. In addition I estimate the property income from ship ownership from 1730 to 1869.

\section{Coal Mining and Quarrying}

For 1842-69 I calculate the share of coal production from England from the share 1854-69 given in Mitchell $(1962,115)$. For $1842-53$ that is taken as $75 \%$, the same share as $1854-5$. I assume quarries had the same output distribution as coal mines.

To estimate returns from coal mines earlier than 1842 I use Clark and Jacks (2007), which estimates by decade from the 1730 s on coal output, pithead prices, coal ground rents, and the share 
of capital returns in output prices, which through the 1730s-1860s averaged 20\%. Table 9 shows these estimates. Coal mineral rents are calculated directly by decade. Capital returns are calculated as $20 \%$ of the total production cost throughout, based on estimates from colliery accounts in the years 1720-1860. All property income, the last column includes a $12 \%$ addition to account for quarries as well as coal mines, based on the post 1842 tax returns (Stamp, 1924, 220).

\section{TABLE 9}

\section{Railways}

Table 10 shows the estimated property income from railways in the 1840 s to 1860 s from the Property Tax returns. This income before 1853 is given for Britain, and is reduced to an English basis by multiplying by 0.84 (Stamp, 1924, 220). After 1853 the report is for the entire UK. The share attributed to Britain is calculated using the relative paid up capital of British and Irish railways (Mitchell, 1962, 225-228), and is then reduced to an English basis by being multiplied by 0.84 . Before 1842 property income from railways is estimated on the basis of the miles of line completed in the UK relative to 1842 (Mitchell, 1962, 225), multiplied by the same property earnings as in 1842.

\section{TABLE 10}

\section{Canals}

Canal and improved river mileage in England from 1750 to 1850 is from Ginarlis and Pollard (1988), table 8.7, 213-215. For 1730-49 I assume the same mileage as in 1750. Property income per canal or waterway mile is assumed to be equal to that of the 1840 s, but converted into current terms by the cost of a day of farm labor. These returns are shown also in table 10 .

\section{Iron Works}

To estimate the profit earnings from iron works 1842-1869 I assume no iron was produced in Ireland, and the earnings in England were the total British earnings multiplied by the share of pig iron produced in England in 1842-1869 (Mitchell, 1962, 131). To project this back as far as the 1720s I use estimates of the tons of English pig iron output per year at benchmark dates (Mitchell, 1962, 131), multiplied by the price of manufactured iron to get an estimate of the value of output 
earlier. It is assumed capital returns are the same fraction of the value of output in the 1842 as in each earlier decade. These returns are also shown by decade in table 10.

\section{Roads}

Another form of capital was the road system. This generally did not produce an explicit rental income, except where roads were turnpiked and maintained from toll revenue, mainly in the period 1750-1840. In other periods roads were paid for by levies on parish occupants, or by local and county rates on property. The rate payments are calculated below. In earlier years when there were direct labor levies for work on the parish roads these will be counted in the calculated labor income in the economy. But if we want to count all sources of income then we need to include the implicit turnpike property income, from the capital invested in turnpike roads and paid for through toll collections, for the years 1696-1869.

To do this I first calculate (roughly) the average miles of turnpike road in England in each decade (Pawson, 1977, 155-6; Bogart, 2005, 440). I calculate the average capital invested in a turnpike road from Bogart, 2005, 454: this shows road expenditure per mile in 1819 prices for the 10 years after establishing a new turnpike. The investment in the first year is $f^{260}$, the second $f^{170}$, the third $£_{100}$, fourth $£, 90$ and fifth $£ 80$. But thereafter there is a steady state expenditure of $£^{7} 75$ per year. I presume the new investment is all of the first year investment, plus all sums thereafter above the presumed maintenance cost of $£, 75$ per mile. This gives $£^{4} 400$ per mile. I convert this cost into the prices of each decade using the level of farm wages (since labor was the major component of this investment). I assume that the return on this capital throughout these years was $5 \%$. These estimates are shown in table 11 .

TABLE 11

\section{Ships}

The volume of shipping services used by the economy expanded dramatically in the Industrial Revolution era, as England became dependent on imported food and raw materials, and as the cities relied on coal from the northern coal fields as their primary energy source. There are statistics on the net tonnage of ships registered in the UK, 1788-1869 (Mitchell, 1962, 217-8). Mostly sailing ships even up to 1869 (when $83 \%$ still sailing tonnage). To get an estimate of what fraction of these ships were operating from English ports I rely on the data in Davis (1956) on the numbers of sailors 
paying the "sailor's sixpence" tax in England and the UK between 1707 and 1828. This allows me to divide up the tonnage from 1788 and later between England and the rest of the UK (the English share is typically $85-90 \%$ of the UK share). For the years $1707-1787$ I estimate the English tonnage from the number of sailors alone assuming it had the same ratio to sailors as in 1788-1897. This

gives the data reported in column 2 of table 12 on the total tonnage of English shipping. Estimating the value of that tonnage is difficult. There are various piecemeal estimates of the cost of a ship, fully rigged and outfitted, for the years 1670-1858. ${ }^{10}$ These give a rough estimate of the cost of a new ship for various benchmark dates, which I interpolate using a very rough cost index (with a .67 weight for wages, and .33 for timber). The overall cost index moves in line with the input price index. I assume in calculating the value of the shipping stock that the average working ship had a value $2 / 3$ that of a new ship (there were substantial losses of ships each year from accidents and loss in war). Feinstein, 1988, 439, gives decadal estimates of the net stock of ships in Great Britain from 1760 to 1850, and from 1851-1869 annual estimates of the UK ship stock, though it is not indicated where the figures for the years before 1851 come. The implied value of the English shipping stock on his measures are also shown in table 12. His numbers are much smaller, one reason being that he assumes the value of the net stock is about half that of the gross stock.

TABLE 12

Davis (1957) and others have investigated the return on ship ownership. Davis conclusion is that ships earned a net return substantially in excess of the risk free return on capital, because of considerable uncertainties on the profitability of voyages because of the hazards of captains, trade, warm, and the weather. Losses of shipping could be insured against, but not losses of income from the failures of ventures. I thus assume that the profit rate on this capital was $5 \%$ beyond that of the return on land or rent changes. This is in line with the estimate of Barney $(1999,137)$ that the King's Lynn firm of W. \& T. Bragge earned an average net profit of 9\% in the 30 years 1766-1795.

Column 6 of table 12 shows the implied rental on ships from the 1700 s to the 1860 s. The final column of table 12 shows the sum of all the non-structure capital incomes - coal mines, quarries, railways, canals, roads, ironworks, gasworks, and ships.

${ }^{10}$ Davis, 1957, 410 estimates the cost $1670-1730$ at $£ 11$ per ton $(£ 6.5$ for the hull and masts, $£ 4.5$ for the rigging), Barney, 1999, 132 quotes ship prices per ton of $f_{9} .7$ in the 1760 s, and $\mathcal{f}_{10.5} 1783$ 90. Ville, 1990, 47-51 gives ship prices in the coal trade 1792-1825. Harley, 1988, 872 quotes prices for 1833 and 1852-8. Graham, 1956, 80, gives prices for 1825 and 1847. 


\section{Other Capital Income}

There are other sources of capital income that are harder to derive direct evidence for. These include income from the machinery and working capital in manufacturing and trade, and capital in road and river transport - horses, wagons, carriage and harbors. These were incomes captured in the years 1842 by Schedule D of the Property and Income Tax, aside from the property incomes I

have already accounted for. For the 1860 s, the total income attributable under Schedule D to England and Wales averaged $£_{105.4}$ m., of which $£ 26.2 \mathrm{~m}$. has been accounted for by the sectors discussed above (Stamp, 1922, 218, 504, 509). The remainder of capital income in the nonagricultural economy, $f_{74.1}$ in the 1860s for England alone, is projected back to 1209 using the formula as in agriculture

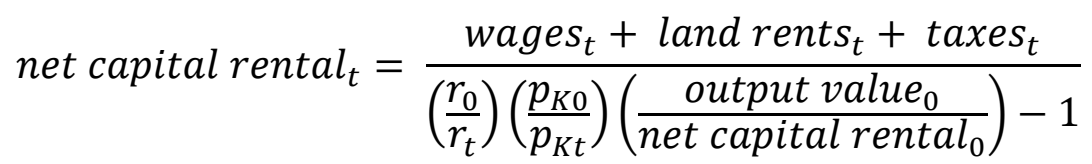

Except that now with the term $\left(\mathrm{p}_{\mathrm{K} 0} / \mathrm{p}_{\mathrm{Kt}}\right)$ I allow in principle for a variation of the price of capital goods relative to the price of output. For this sector of manufacturing and trade I assume that the the interest cost is the risk free interest rate plus a premium for risk of $5 \%$. This produces the numbers in table 8 .

\section{Net Nominal National Income}

I can now calculate the sum of all implied property incomes 1209-1869, and adding this to wages, the net nominal national income. These estimates by decade are shown in table 13. Nominal national income for England in the 1860s averages on this calculation $£ 635 \mathrm{~m}$. Feinstein (1972) estimates domestic factor incomes plus indirect taxes in the UK economy as averaging $£, 840$ million a year in the 1860s, gross of depreciation. Deducting depreciation, and calculating England's share of UK income by assuming that incomes per person in Wales and Scotland were the same as in England, and incomes in Ireland were half those of England implies that English net national income in the $1860 \mathrm{~s}$ was $£, 581 \mathrm{~m}$. (Feinstein, 1972, table T1, T120). So the estimate here for the 1860s exceeds Feinstein's by 9\%. The difference stems mainly from the larger estimated wage income above. This estimate is also close to the estimate in Deane and Cole, 1967, 166, that British 
domestic income (gross of some capital depreciation) was $f_{6} 648 \mathrm{~m}$. in 1861 and $f_{877} \mathrm{~m}$. in 1871. This implies an English domestic income in the 1860s of $f, 599 \mathrm{~m}$.

\section{TABLE 13}

Table 13 also shows the share of wages, land rents and capital in national income, where that share of wages is calculated as

$$
\frac{\text { wage income }}{\text { (NNI-indirect taxes) }}
$$

This calculation suggests the share of wages varied between 48 and $76 \%$ of national income, reaching the highest share, $76 \%$, in the 1860 s. The share of land rents is

$$
\frac{\text { land rents }}{(\text { NNI-indirect taxes })}
$$

This share before 1800 varied between 15 and 30\% of national income, but by the 1860 s had fallen to $9 \%$. The share of capital is calculated as the residual. This method assumes that the burden of indirect taxes was born equally by labor, land and capital owners.

Table 13 also shows the share of income that comes from the agricultural sector over time. Since we assumed a certain allocation of labor between farming and the rest of the economy, I can also estimate the implied relative value of output per worker in agriculture compared to the rest of the economy. That ratio is shown as the last column of table 13. 


\section{Prices}

$\mathrm{P}$ is an index of the price of output. Here a crucial decision that must be made. There are two potential output price indices.

$\mathrm{P}_{\mathrm{NDP}}=$ price of net domestic output

$\mathrm{P}_{\mathrm{DE}} \quad=$ price of domestic expenditures (including net investment),

The two are related in general through the formula

$$
\ln \left(P_{N D P}\right)=\left(\frac{1+\theta}{1+\phi}\right) \ln \left(P_{D E}\right)+\left(\frac{\phi(1+\theta)}{1+\phi}\right) \ln \left(P_{X}\right)-\theta \ln \left(P_{M}\right)
$$

Where $\mathrm{P}_{\mathrm{M}}=$ price of imports (wholesale prices), and $\mathrm{P}_{\mathrm{X}}=$ price of exports (free on board), $\theta$ is the ratio of the value of imports to NDI, and $\phi$ is the ratio of the value of imports to domestic expenditure. For simplicity I assume throughout that $\theta=\phi$, or that commodity trade balanced. ${ }^{11}$ In this case the above formula becomes the much simpler

$$
P_{N D P}=P_{D E}\left(\frac{P_{X}}{P_{M}}\right)^{\theta}
$$

Should $\mathrm{P}$ be the price of the output produced with domestic factors of production, $\mathrm{P}_{\mathrm{NDP}}$ ? $\mathrm{Or}$ should $\mathrm{P}$ be the price of the goods purchased by English consumers and producers, $\mathrm{P}_{\mathrm{DE}}$ ? Before 1700 this makes little difference, since $\theta$ is small and the ratio $P_{X} / P_{M}$ deviates little on average from 1. But after 1760, $\theta$ quickly became much larger. By the 1860 s for England it would be 0.25 or more. And the ratio $\mathrm{P}_{\mathrm{X}} / \mathrm{P}_{\mathrm{M}}$ declined substantially in the years 1790 to 1860 . As figure 6 shows, in the Industrial Revolution era export prices, principally those of textiles and iron and steel, declined relative to import prices. Thus the productivity of the economy, measured in terms of NDP was increasing more than the productivity, measured as consumption per unit of input, in decades from the 1790 s to the 1860 s.

The argument for using the NDP measure of prices, to measure both output and the efficiency of the economy is that such a measure indexes the output and efficiency of production in England, and this is the core concept that we seek. The argument against this, as we shall see, is that if there

\footnotetext{
${ }^{11}$ In practice the UK was a recipient of a positive balance of property income from abroad, but this represented only 2-4\% of national income in the years 1855-69 (Feinstein, 1972, T4).
} 
Figure 6: Export Relative to Import Prices, England, 1690-1869

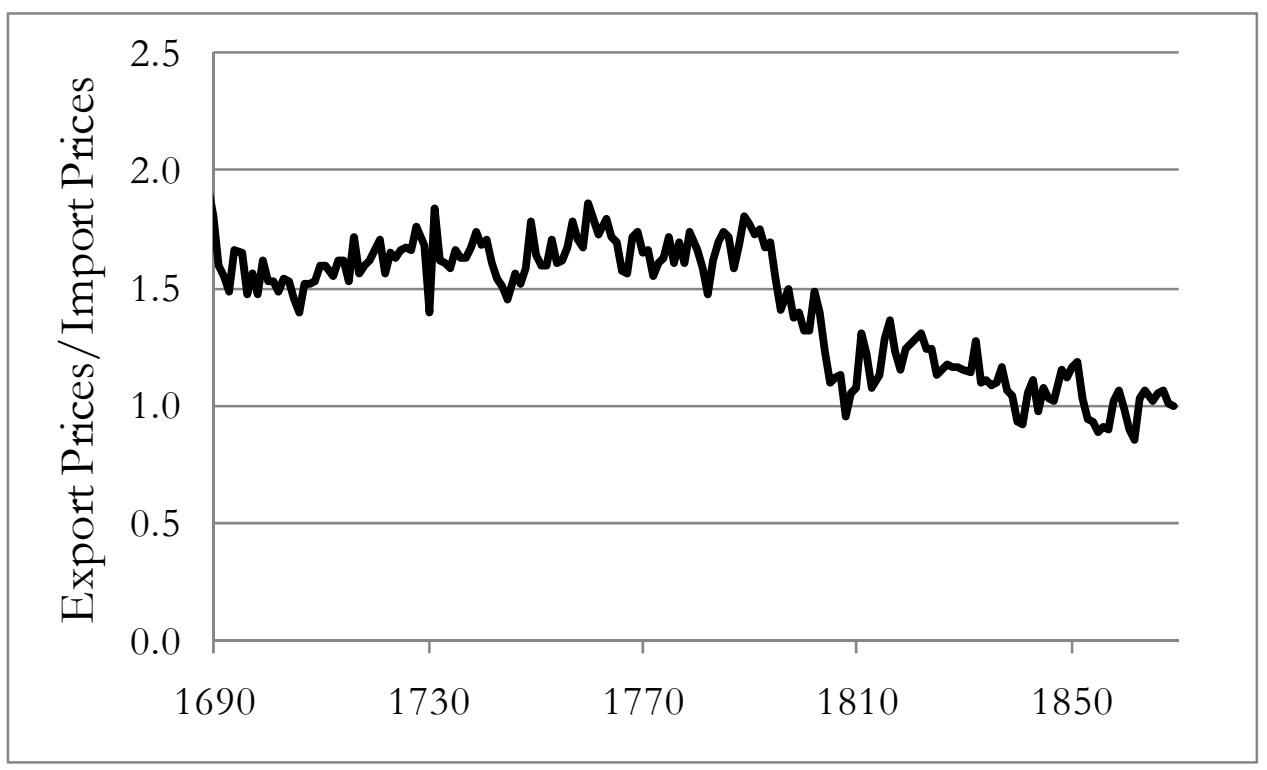

is differential productivity advance across industries then quite accidental factors concerning the location of industrial activity can result in dramatic differences in the measured output and productivity advance across regions, differences that in no way measure differences in the inventiveness or dynamism of these economies. The alternative measure of efficiency, using the expenditure price index, indicates better the success of the economy at improving human welfare. But it suffers from the deficiency that events elsewhere in the world, completely unrelated to this economy, will influence this measure. In the case of England in the Industrial Revolution, for example, improvements in the cultivation of cotton in the US South resulted in lower input prices for cotton goods consumed in England, and hence a higher measured efficiency.

The price indices are calculated as geometric indices. i. e.

$$
P_{M}=\prod_{i} P_{i}^{a_{i}}
$$

where the $a_{i} s$ are the shares in import costs of each good, and so sum to 1 .

$$
P_{D E}=\prod_{i} P_{i}^{b_{i}}
$$


where the $b_{i} s$ are the shares in domestic purchases of each good, and again sum to 1 . With this specification the GDP price index will be of the form

$$
P_{N D P}=\prod_{i} P_{i}^{c_{i}}
$$

where $\sum_{i} c_{i}=1$, but the individual weights can be positive or negative. Negative weights will correspond to imported commodities.

The domestic expenditure price index is formed from 11 principle component indexes, whose weights for each period are shown in table 14. But each of these component indices in turn is composed of a weighted average of the price of various commodities. The individual price series were derived as the estimated parameters on year indicators of regressions of the form

$$
\ln \left(P_{i t}\right)=\sum_{k} \beta_{k} D T Y P E_{k}+\sum_{t} \phi_{t} D_{t}+\varepsilon_{i k t}
$$

where DTYPE is a set of indicator variables for each type of a product, where a type was defined by location, purchaser, characteristics and measuring unit. In this I try and control for variations in the size of units across sources, and in the quality of the product. This is important because both the quality of the product and the size of the measures varied across sources, even for very homogenous commodities in the same place at the same time. In London in 1827, for example, the Clothworkers Guild paid 20 d. per gallon for milk, Bethlem insane asylum 13 d., and the King's Household 24 d., a range in price for a seemingly standard product of nearly 2:1. In earlier years where observations are missing for some years they were interpolated as an 11 year centered moving average of the years with prices, where this was possible.

\section{TABLE 14}

\section{Expenditure Prices}

The weights of the subcategories in this price index change over time to reflect two things. First the changing structure of expenditure as the economy became richer in the years 1820-69 following the Industrial Revolution. Second the decline in the number of available price series as we move to the earliest years of the thirteenth century. 


\section{Food Index}

This is the most important of the sub-indices, with a weight of at least .45 in the overall expenditure index. This index consists of the weighted average of a number of sub-indices: starches, meat, dairy, fish, fats, drink, sugars, salt and spices. The weights were as in table 15.

\section{TABLE 15}

Starches: The component series are wheat bread, barley, oats/oatmeal, peas, potatoes, and rice. The relative weights of each in the starch index are shown in table 16. Up until 1869 wheat bread was the single most important item of consumption in the economy, getting a weight of at least 9\% in the domestic expenditures index, and at least 13\% in the workers' cost of living index. However, rather than use bread prices directly I approximate them based on the prices of wheat, labor (skilled craftsmen), salt, wood fuel and candles. This is done because there is evidence that government regulation of the bread market before 1815 must created changes in the quality of bread sold over time. Bread prices are thus estimated (assuming fixed coefficients) as the weighted average of wheat prices, craft labor, firewood prices, salt prices and candle prices.

\section{TABLE 16}

The available bread prices before 1816 are mainly those for London, but these were regulated by statute before 1815 . The statute stipulated how much flour was to be produced per bushel of wheat, and how many loaves produced from this flour (Webb and Webb, 1904). It also set the "allowance" the baker received to turn the flour into bread.

If bread prices measured bread of constant quality over time then they should have a very close relationship to the price of wheat. This is because wheat was the overwhelming cost in making bread. A breakdown of the costs of bread baked for the Navy in 1767 suggests that the price of bread should be nearly proportional to that of wheat, since wheat constituted $92 \%$ of the costs of making bread (Beveridge 1939, p. 542). Robert Allen objects that this cost share for wheat is too high, leaving out the required managerial and capital returns of the baker (Allen, 2008, ---). But if we calculate the share of wheat costs in bread from the details of the London assize 1797-1813 then we still find wheat costs were a full 81\% of the price of bread (Parliamentary Papers, 1804, 11-12, Parliamentary Papers, 1812-13, 3, 12). The other elements of costs in 1797-1804 were labor 4.7\%, fuel $1.8 \%$, yeast $1.6 \%$, salt $1.5 \%$, candles $0.4 \%$, and profits $10 \%$. If bread was of constant quality then bread prices in other years should be predictable from these costs. 
Figure 7 shows the price of bread in London relative to its cost over time: where the cost elements that I can observe are wheat, labor, fuel, salt and candles. Yeast is assumed to have a cost proportionate to wheat. And profits are assumed always as $10 \%$ of total costs. The figure shows that the quality of bread cannot be constant over time. After the lifting of the bread assize in 1815

Figure 7: The Bread Price/Cost Ratio,

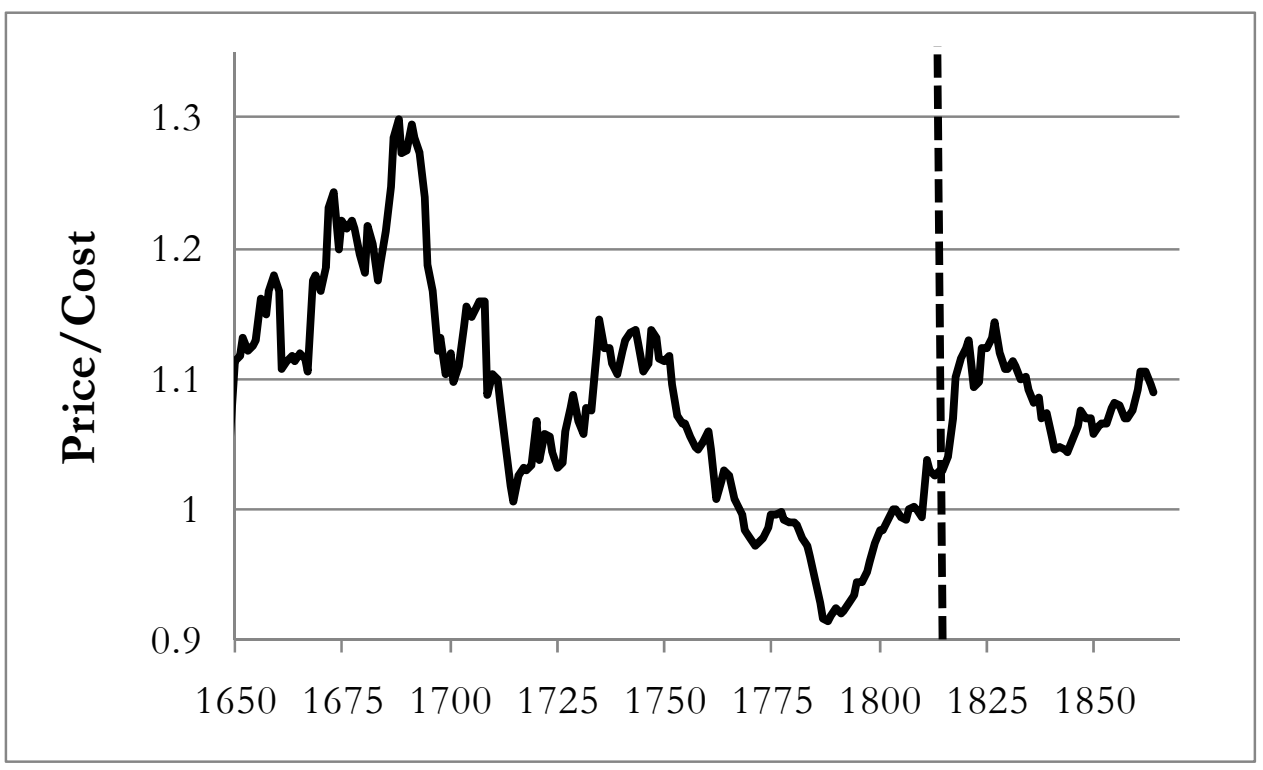

the price of bread quickly rose nearly $10 \%$ relative to the cost. Around 1790 bread sold for about $8 \%$ less than its cost of production - so then either bakers were making negative economic profits, or the quantity of wheat in the standard loaf had been, in effect, reduced. ${ }^{12}$ Earlier there are other periods where prices are substantially above costs. ${ }^{13}$ In this situation it seems much safer to work up the implied bread price from its component costs than to assume that there were vast swings in the compensation of bakers, with those of the late $18^{\text {th }}$ century subsidizing their bread sales, and those of other periods garnering substantial profits.

\footnotetext{
12 The London assize called for $240 \mathrm{lbs}$ of flour to be made from 6.5 bushels of wheat, or roughly 390 pounds of wheat. The other $150 \mathrm{lbs}$ were lost as bran in the milling process. By milling less finely to produce a coarser flour, more loaves could be made from a bushel of wheat.

13 This does not seem to be a defect of the wheat price series. That series for the years 1771-1869 is very close to the Gazette series, taken from the whole country, of average wheat prices. Yet in this period there is a nearly $20 \%$ variation in the price of bread in London relative to wheat prices.
} 
Oatmeal prices were used in years where they were available. In other years oatmeal prices were interpolated using the price of oats.

Meat: The component series are beef, cattle, mutton, sheep, pork, pigs, poulty, and eggs. Meat is sold by the pound in later years. Earlier to infer meat prices I have to use the prices of live animals. This will only accurately represent meat prices if animal weights did not change. Since the live animal series are used in the years 1209-1600, where there is no sign of any yield increases in arable crops, this seems a reasonable assumption. The weights are given in table 17.

\section{TABLE 17}

Dairy: This series is relatively simple, with just milk, butter and cheese, and relatively unchanging weights throughout. The weights are also shown in table 17.

Fish: The fish series is a weighted average of three components - herring, salt cod, and salt salmon. The weights are given in table 18.

\section{TABLE 18}

Drink: This series incorporates cider, beer, wine, tea and coffee. Here the weights change greatly over time as is shown in table 19. Over time the favored drinks of the population changed greatly, in part as a result of substantial changes in the relative prices of the different beverages.

TABLE 19

Sugars: Honey, Currents/Raisins, Sugar, Treacle. Currents and raisins were mainly used as sweeteners in English cooking. The weights are given in table 20.

\section{TABLE 20}

Fuel: The fuel index has three components - wood and peat, charcoal, and coal. Charcoal was a smokeless version of wood used by the richer. Coal was the smokiest fuel, and hence least desirable. Because of the high cost of transporting fuel, the use of each was dictated by local supply and transport conditions. By the eighteenth century coal dominated in big cities like London, but wood 
fuel supplies still dominated in countryside locations without good water transport connections. Table 21 shows the weighs assigned over time to each fuel type.

\section{TABLE 21}

Lodging: The method for forming the rental values of housing of constant quality is described in Clark (2002). For this estimation I have 5,125 observations in total, 757 for the years before 1500 . Over the Industrial Revolution, with greater urbanization, the rental value of housing increased greatly relative to the general price level. Consequently the weight given to housing in table 14 is increased in this period. Greater weights are also assigned in the years before 1375 when the return on capital invested in housing was much greater than in subsequent years, more than $10 \%$, implying that correspondingly rental values would be greater. Since house rent estimates only go back as far as the 1290s, for earlier years house rent is estimated as the average of 1290-1349, but indexed by the relative price level in the earlier year compared to the average price level of 1290-1349.

Light: The component series here are Tallow Candles (in the thirteenth century tallow itself), Wax Candles, Sperm-Oil, and Coal-Gas. An issue is what weight to give gaslight in this index. After 1815 the price of gas illumination was dramatically below that of candles. It was reckoned that 19 cubic feet of gas had by 1832 the illumination equivalent to a pound of tallow candles (Matthews, 1832, 326). Table 22 shows the cost by decade from 1815-1869 of a pound of tallow candles compared to the equivalent amount of 19 cubic feet of gas. When gas was being first introduced it cost only about $40 \%$ that of candles. But by the 1850s it cost only about one sixth that of candles.

\section{TABLE 22}

It has been argued, however, that before 1870 gas illumination was found only in middle and upper class homes (Matthews, 1986). However, the poor as well as the rich benefited from the use of gaslight for street illumination, for pubs, and for shops. By 1876 there were 54,000 street lamps lit by gas in London alone (Chubb, 1876, 350). It seems thus that the transformation of public spaces by gas light in the years 1815-1869 should get some weight in the cost of living of even the poor.

In terms of the weight in the domestic expenditure price index, by the 1860 s gas consumption measured just in the price of gas was about $1 \%$ of GNI. In the 1840 s it was about $0.5 \%$ of GNI (Matthews, 247). Table 23 shows the weights in the lighting index over time. To allow for the poor having less access to the benefits of gaslight, in the workers' cost of living index gas is counted with 
only half this national weight. The other weight within the COL light series is all devoted to tallow candles.

\section{TABLE 23}

Clothing and Bedding: The sources for prices here are varied - wool cloth, woolen blankets, linen cloth, cotton cloth, silk thread, stockings, complete suits of clothing (other than stockings), boots and shoes, leather gloves. Table 24 shows the weighs assigned over time to each item of clothing or bedding.

TABLE 24

Services: The pre-industrial economy had a vast array of domestic servants: cooks, housemaids, grooms, coachmen. This shows even in the 1851 census. At that date, weighting men and women, boys and girls by their earnings, $13.1 \%$ of the labor force was engaged in some type of personal service (Parliamentary Papers, 1852-3, Table 25, 222-227). Wages were 64\% of national income in 1851, so that this implies that $8.4 \%$ of expenditure was on service of some kind: domestic servants, barbers, doctors, nurses, gardeners, and teachers. Thus the share of expenditure devoted to personal service is assumed at $8 \%$ in 1840-69, and somewhat lower in the earlier years (table 14).

Manufactures: Certainly by the end of our period, 1869, the average person was consuming a quantity of manufactured goods aside from clothing and bedding. There were wooden utensils, furniture, brooms, hairbrushes, glasswares, cutlery, pottery, pewter, cooking implements, garden tools, haberdashery, and spectacles. An estimate of the potentially substantial share of these goods in expenditure comes from insurance policies from the years 1750-1850 analyzed by Sidney Pollard (Pollard, 1988). The policy value of the average house insured 1801-1850 was $f^{449}$. At the same time the value of the contents insured averaged $f^{242}$, more than half the structure value (Pollard, 1988, 250, 256). The contents consisted of clothing, bedding, plate, jewellery, housewares and furniture. Unfortunately Pollard does not subdivide this category. But if even just half the value of housewares was for items other than clothing and bedding, then annual purchases of housewares and furniture must have been substantial in nineteenth century England.

Using primarily the copious records of the Founding Hospital in London from 1759-1856 I am able to derives price series for many of these items in the Industrial Revolution period, which I class under "manufactures." As table 14 shows these are given a very modest weight in the overall expenditure index, but were included as a potential area of significant declines in relative prices as a consequence of the Industrial Revolution. 
Investment Goods: Under this heading are included construction materials (bricks, timber, manufactured iron), as well as implement prices (spades and shovels), and window glass.

Appendix table 1A shows the decadal level of each of the individual price series and the resulting 11 major component price indices.

\section{Export Price Index}

Table 25 gives total calculated exports and imports from England from 1784-1856 taken from Davis (1979), and the implied average share of exports and imports of Net National Income. The total value of English exports is inferred from UK exports for 1834-6 and later, from British exports for 1784-6 to 1824-6. This is done by assuming that England was 84\% of British exports, and that Ireland received the same share of British exports in later years as in 1824-6. It was assumed throughout that all cotton goods, wool cloth, manufactures, iron, coal and sugar exports from the UK were from Britain, with England supplying 84 percent of each. All linen exports from the UK were assumed to come from Ireland. Table 24 also lists for the major exports that I have price series their shares of total English exports on these assumptions. The price index for exports was based on a weighted average of these prices, with the weights changing each 10 years.

\section{TABLE 25}

Table 26 shows the total value of exports and imports for England for 1699-1774, where the export and import data comes from Davis (1962), and refers to England. Table 26 also shows the share of exports for the commodities for which I have prices over these years.

\section{TABLE 26}

The price index for exports was thus composed of indices with the indicated weights for cotton cloth, woolen cloth, manufactured iron, pig iron, manufactures, coal, sugar and wheat. These should be FOB prices, but I use as the nearest approximation domestic retail prices.

\section{Import Price Index}

The main imports of England at various periods are also listed in Tables 25 and 26, taken also from Davis $(1962,1979)$. The total value of English imports is inferred from UK imports for 1834- 
6 and later, from British imports for 1784-6 to 1824-6, and from English imports for 1699-1701 to 1772-4. This is done by assuming that England was 84\% of British imports. For Ireland after 18246 I assume that Irish exports to England were the same in nominal terms in 1834-6, 1844-6, and 1854-6 as in 1824-6. I also assume that Ireland took an amount of the imports of foods to the UK as equaled its exports to England in these years. For each good after deducting the assumed share of Ireland I assume $84 \%$ of the import went to England. In later years the dominant imports were raw materials or processed farm products - cotton, grains, sugar, timber, wool, tea, silk, tallow, oils, flax, hemp, indigo, wine, butter, meat, spirits and copper. Earlier there are substantial manufactured imports into England in the shape of linens.

The wholesale prices of many of these imports are available from the work of Thomas Tooke and William Newmarch for 1782-1859, and 1854-1869 from the average prices of imports to the UK recorded in government trade statistics (Mulhall, 1899, 471-77).

\section{Real NDI and real NDP}

Table 27 shows the resulting decadal price indices, $\mathrm{P}_{\mathrm{DE}}, \mathrm{P}_{\mathrm{NDP}}, \mathrm{P}_{\mathrm{X}}$, and $\mathrm{P}_{\mathrm{I}}$. All the indices have 1860-69 set at 100. Because of the more rapid decline of export compared to import prices in the years 1760-1869, $\mathrm{P}_{\mathrm{DE}}$ rises more than $\mathrm{P}_{\mathrm{NDP}}$. Thus real NDI grows more slowly in the Industrial Revolution era than real NDP. Table 27 also shows estimates of the average of import and export values to NDI for each decade where this is available.

\section{TABLE 27}

Table 28 shows decadal estimates of real NDI, real NDP, real NDI per capita and real NDP per capita. Figure 8 shows the decadal estimates of NDI per capita from the 1200 s to the 1860 s. What is remarkable here is first the high implied pre-industrial levels of income per capita in some periods: 1209-1239, and 1380-1509. Estimated incomes in some decades here exceeded average incomes in England for all decades before the 1820s. There were also periods of quite low incomes per person, as in 1270-1329. The high incomes of the 1200 s to 1240 s may be a statistical aberration. The data for the 1200s, for example, is for 1209 only and based on a couple of wage quotes only, with the

prices of only a handful of commodities. But the data for the 1440s and 1450s, when estimated income per person exceeded that of the 1840s, is rich and detailed.

TABLE 28 
The implied estimated growth rates of NDP per capita in the Industrial Revolution era are low relative even to the relatively pessimistic estimates of Knick Harley and Nick Crafts from primal sources. Thus over the hundred years from the 1760 s to the 1860 s real NDP per capita increased by $60 \%$, at an average annual rate of $0.47 \%$. Crafts and Harley estimate an annual growth rate of GDP per person in this interval of $0.55 \%$ (Crafts and Harley, 1992). This in turn would imply an overall increase of GDP per person of $73 \%$ in these years.

Growth measured in terms of national income was even slower because of the decline in the terms of trade. Thus income per person (NNI) increased by only $48 \%$ over the hundred years between the 1760 s and the 1860 s, implying an annual growth rate of only $0.39 \%$. Figure 8, showing income per person in England from 1200s to 1860s, implies that this makes the discontinuity of the Industrial Revolution less clear. Was the Industrial Revolution just the acceleration of a period of slow growth beginning around 1600 ?

\section{Figure 8: NDI/N, 1200s-1860s}

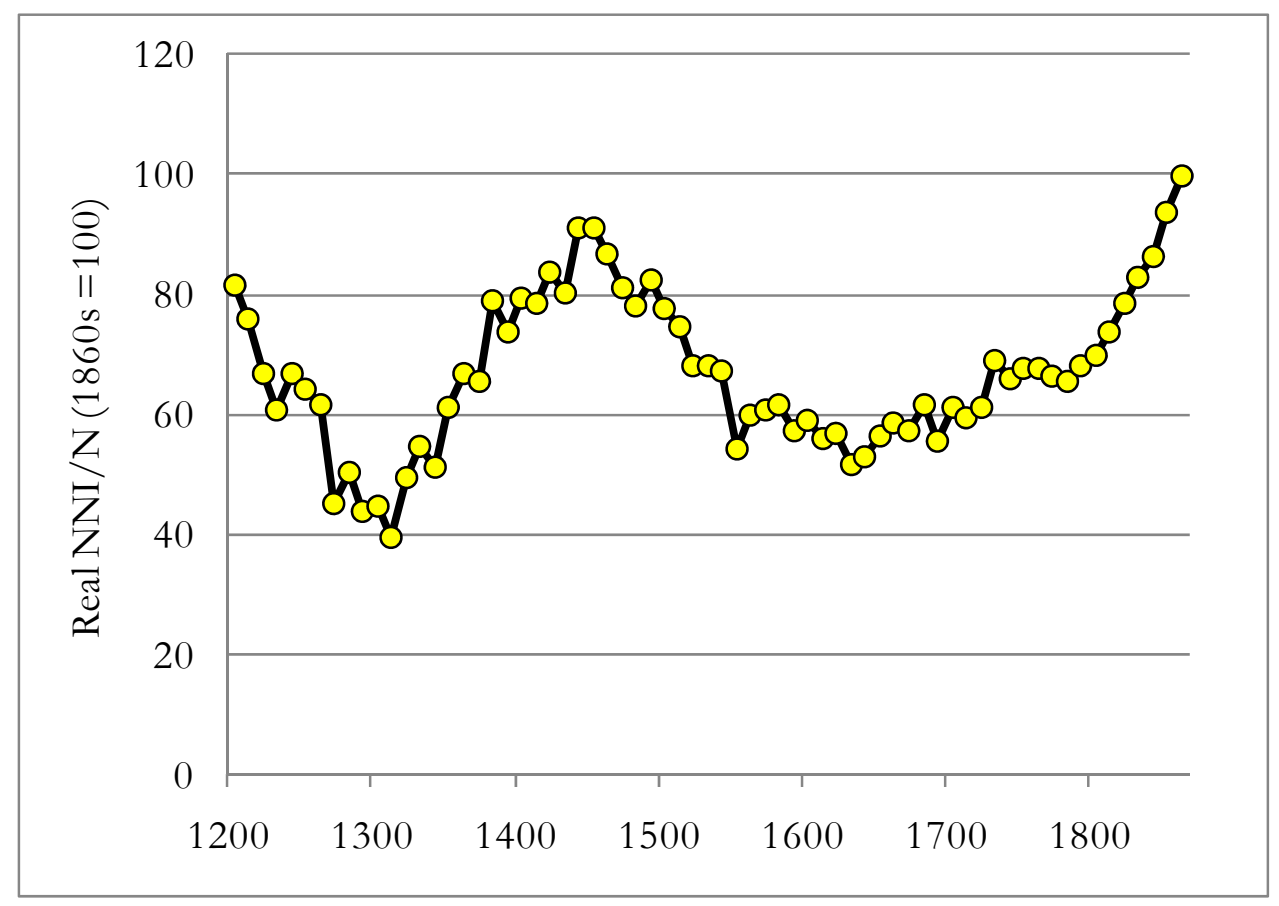




\section{Cost of Living Index and Real Wages}

One big issue in the Industrial Revolution era is the standard of living of workers. That requires a cost of living index which has different weights from the national price index. The cost of living index aimed for here is one that applies to the average wage earner, not the poorest such as agricultural workers (such an index is reported for agricultural workers in Clark, 2001, and Clark, 2007b).

Table 29 shows the weights in the principal components of the workers cost of living index for various periods. The principal difference here is the larger weight given to food, and the much smaller weight given to services. These weights are derived from Clark (2001, 2005), which reports contemporary surveys of worker consumption patterns in England, mainly for the years 1789-1869. Within the sub-indices the weights also differ. Within the food category, starches are given greater weight and meat and dairy products less (table 30). In drink, beer is much more important than wine in the cost of living index (table 31). In clothing, silk is excluded from the cost of living index.

TABLES 29, 30, 31

The resulting Cost of Living (COL) index by decade is shown in table 27. Table 28 shows the implied decadal real wage. Real wages were also surprisingly high in the pre-industrial era, as figure 9 shows. What is also evident is that real wages rise more than national income per person in the Industrial Revolution era. Real wages rose $74 \%$ between the 1760 s and the 1860 s, compared to an only $48 \%$ increase in real income per person.

Real wages rose faster than real income per person mainly because of the increased share of wages in national income over these years (caused by the decline of land rents as a share of national income). As table 13 shows, labor income was $59 \%$ of all income in the 1760 s, but $65 \%$ by the 1860s. Land income fell over the same years from 20\% to $8 \%$. A small part of the reason for the faster growth of real wages than of incomes comes from the different movement of the cost of living of workers, compared to the cost of expenditures as a whole. The COL index shows a 45\% rise 1760 s to 1860 s, compared to a $52 \%$ rise in the Domestic Expenditures price index (and a $40 \%$ rise in the GDP deflator).

The COL rose less than general expenditure prices principally because of the much smaller weight in this index of services - teachers, doctors, nurses, cooks, house maids, gardeners, coachmen. These were $8.7 \%$ of all expenditures, but only an estimated $1.3 \%$ of the expenditures of 
Figure 9: Real Wages by Decade, 1200s-1860s

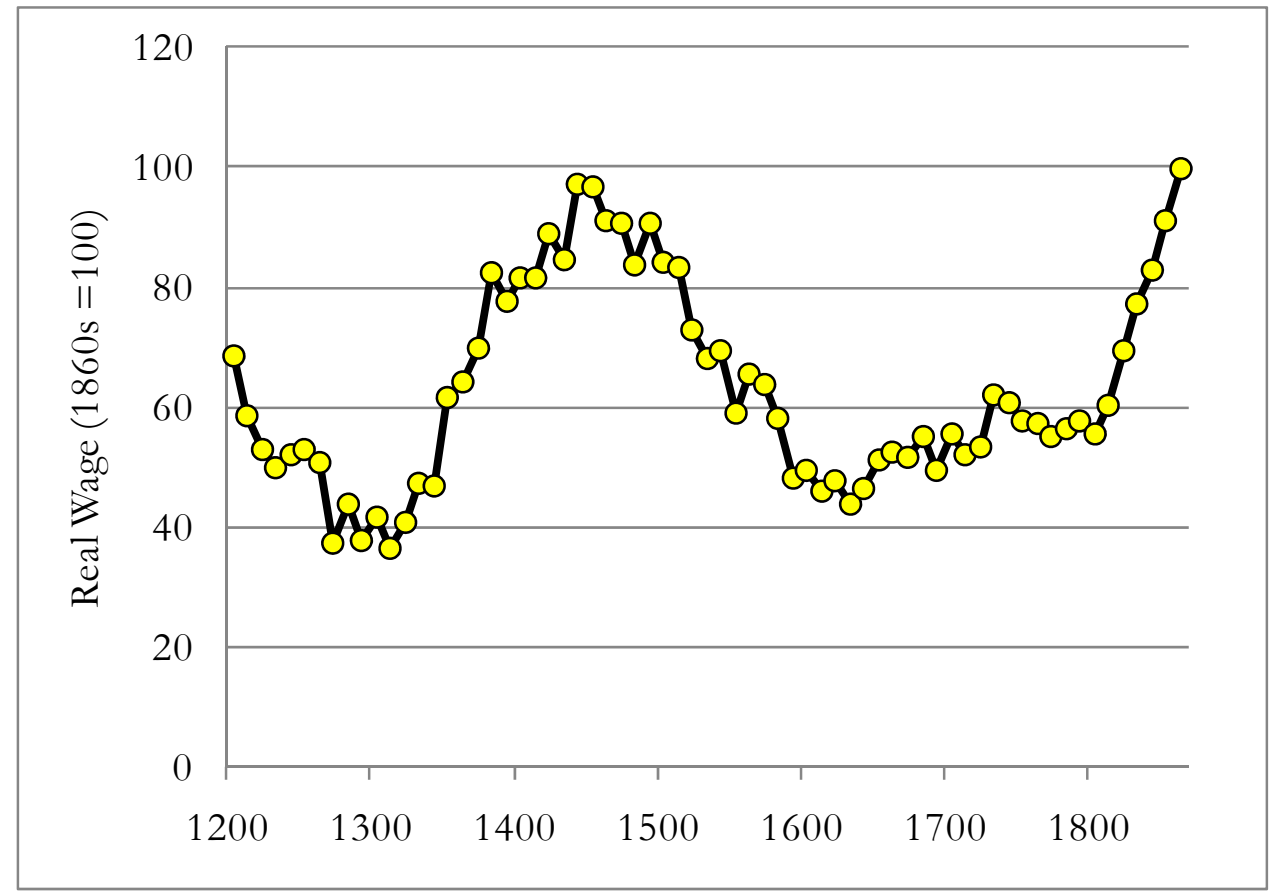

Figure 10: Real wages and Real Income per Capita by Decade, 1760-1869

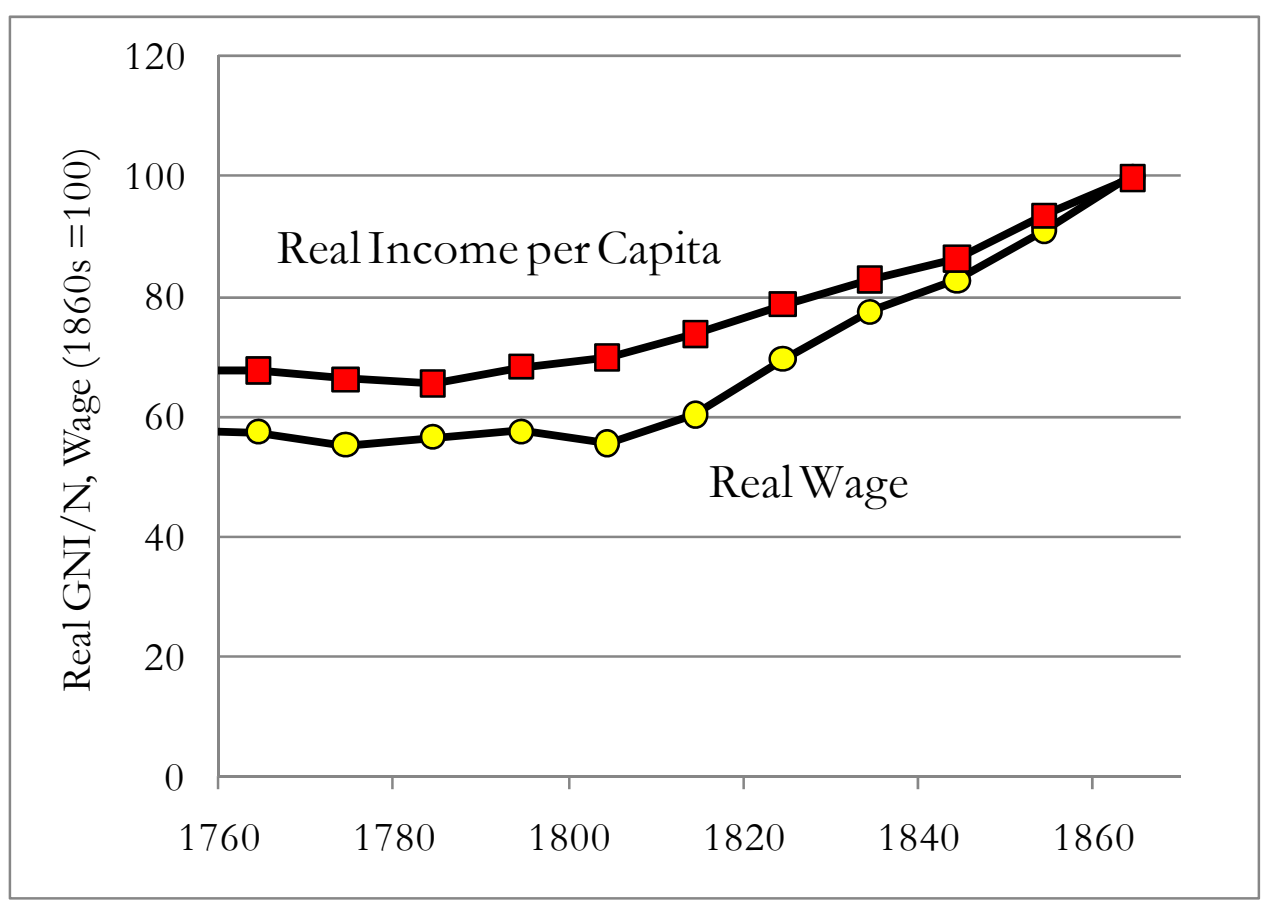


workers. Because urban wages rose by $148 \%$ in these years, which was more any other expenditure price, the expenditure deflator rose by more than the cost of living of workers. Indeed the higher weight given to services explains most of the difference in aggregate between these two indices over these years. The weights for other items did differ substantially, as table 32 shows. The poor ate much more grain and potato products. But here the rate of price increase did not differ much from the average good. The workers drank more beer, whose price increase was more than the average, but in compensation richer consumers were assumed to drink more wine. But since there were so many changes in weights and relative price movements, as table 32 shows, mostly these effects cancelled out in terms of the rise of the COL versus $\mathrm{P}_{\mathrm{DE}}$.

\section{TABLE 32}

\section{Efficiency}

Since population changed greatly over the years measures such as real income per person or real wages do not reveal the efficiency level of the economy directly. To calculate that we need to estimate equation (1) above, which looks just at the weighted ratio of input prices (net of indirect taxes) to output prices. We now have all the prices and weights we need to estimate expression (1): $r$ $=$ real interest rate, $\mathrm{p}_{\mathrm{K}}=$ index of price of capital, $\mathrm{w}=$ index of wages, $\mathrm{s}=$ index of farmland rents, $\mathrm{p}$ $=$ price index for output, $\tau=$ share of national income collected in indirect taxes, and $\mathrm{a}, \mathrm{b}, \mathrm{c}$ the shares in each year of the factor payments of capital, labor and land respectively. The shares of labor, land and capital are calculated based on output values net of indirect taxes, with poor rate collections attributed either to land or capital. Though the index has the Cobb-Douglas form, the shares of labor, capital and land are updated annually in calculating the year to year movement of efficiency, implying there is no underlying assumption of a Cobb-Douglas technology. In fact the index is agnostic on the form of the production function.

Equation (1) can be rewritten as

$A_{t}=\left[\frac{\left(r_{t}+\lambda\right) P_{K t}}{P_{t}\left(1-\tau_{t}\right)}\right]^{a}\left[\frac{w_{t}}{P_{t}\left(1-\tau_{t}\right)}\right]^{b}\left[\frac{s_{t}}{P_{t}\left(1-\tau_{t}\right)}\right]^{c}$

Economic efficiency is thus the geometric weighted average of the real rental of capital, the real price of labor, and the real rental of land. The capital stock earlier consists mainly of a combination of structures (houses, inns, mills, shops, warehouses) as well as farm working capital (animals and 
grains) and non-farm working capital. It thus seems reasonable to assume that the price of this capital moves in line with general prices in the economy, so that $\mathrm{P}_{\mathrm{Kt}}=\mathrm{P}_{\mathrm{t}}$. This assumption implies that the capital goods sector experienced as much efficiency growth as the rest of the economy. In implementing this index of productivity the question arises about what value to give to $\lambda$, the risk premium on capital. Since early interest rates are high, the greater is $\lambda$, the smaller will be the capital cost contribution to productivity levels in earlier years. But the capital stock was a combination of houses, with little risk premium on their return, farm capital with an intermediate risk premium, and commercial capital with a significant risk premium. As a compromise I take $\lambda=3 \%$.

Figure 11 shows productivity from 1209 to the 1860s calculated with the expenditure prices from England. It shows the overall efficiency of the economy in translating inputs into real income, whether the purchases were produced domestically or abroad. The decades 1200-9 to 1280-9 are shown as a dotted line to emphasize how much more tentative the estimates are for these decades

Figure 12 shows productivity over the same period calculated based on the prices of English output only. The effect of using the NDP price index in the years before 1870 is shows mainly in the greater rise of efficiency in the Industrial Revolution period, the 1780 s to 1860 s. Measured using expenditure prices the productivity growth rate is 0.37 percent per year from the 1760 s to 1860 s. Measured using expenditure prices the productivity growth rate for the 1760 s to $1860 \mathrm{~s}$ is 0.37 percent per year. This 0.45 for productivity growth measured on the basis of output prices is similar, but again below, what has been regarded as the pessimistic rate of 0.55 percent per year calculated by Crafts and Harley (1992), which is done on a GDP basis. But I will discuss further below why the expenditure based index seems more appropriate. Table 32 shows both these sets of productivity measures by decade.

\section{TABLE 33}

Figure 13 shows why the measured efficiency of the economy moves as it does from the 1200 s to 1860 s, by looking at the components of equation (2) for efficiency. The reason that measured efficiency is so unexpectedly high in the years before 1350, despite the relatively low levels of output per person, is the high calculated underlying real interest rate in this epoch. Real interest rates in the thirteenth century were 2.5 times as great as in the eighteenth and nineteenth centuries. Since I have assumed that in both farming and non-farm activities there was a fixed ration for working capital to output, this raises the weight of capital, $a$, in the productivity equation (1) in these years, since the share of capital in all payments is assumed to rise. Had I assumed that capital entered the production function in a Cobb-Douglas fashion, with a fixed share of payments to factors going to 
Figure 11: Productivity, 1209-1869 - measured relative to expenditure prices

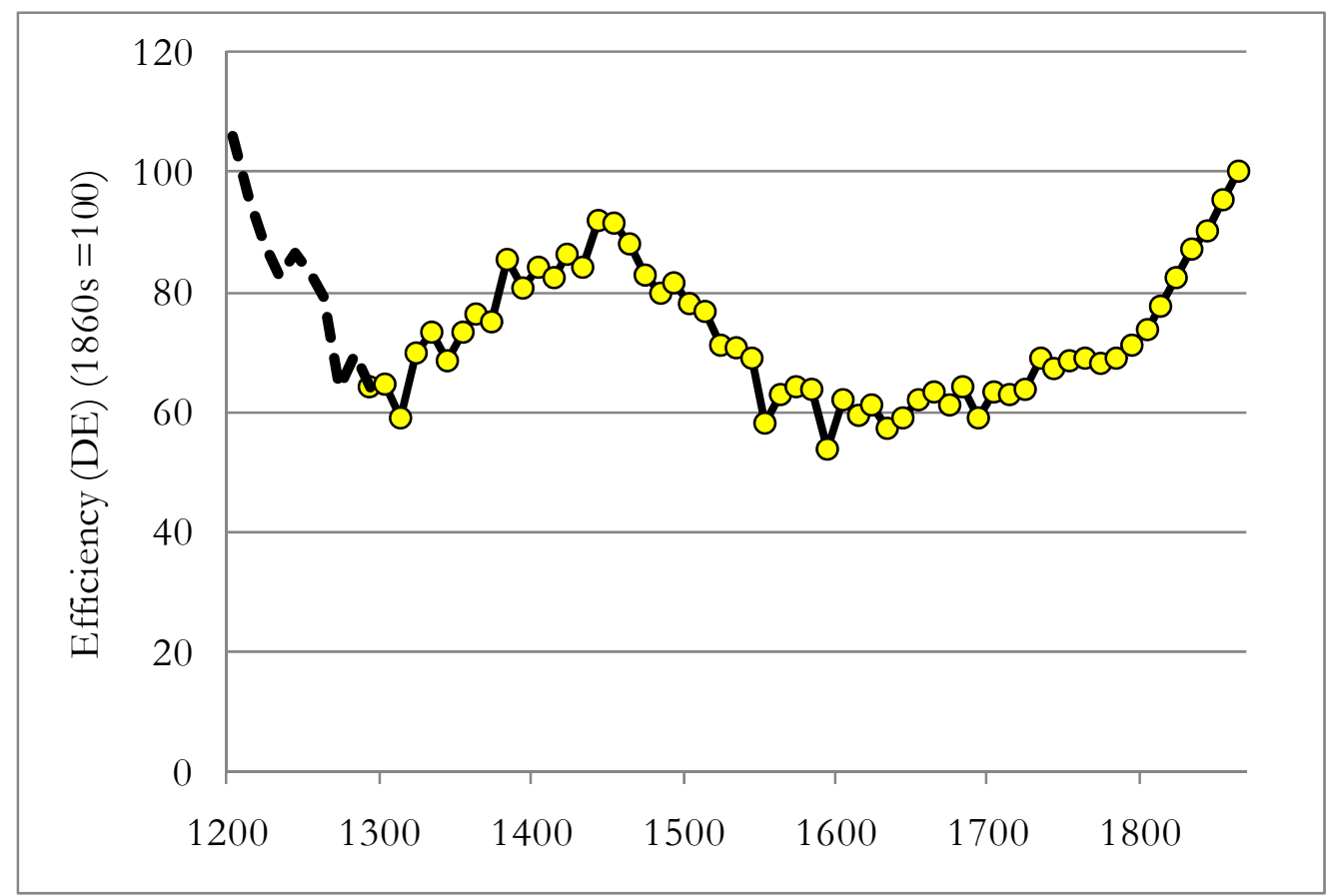

Figure 12: Productivity, 1209-1869 - measured relative to GDP prices

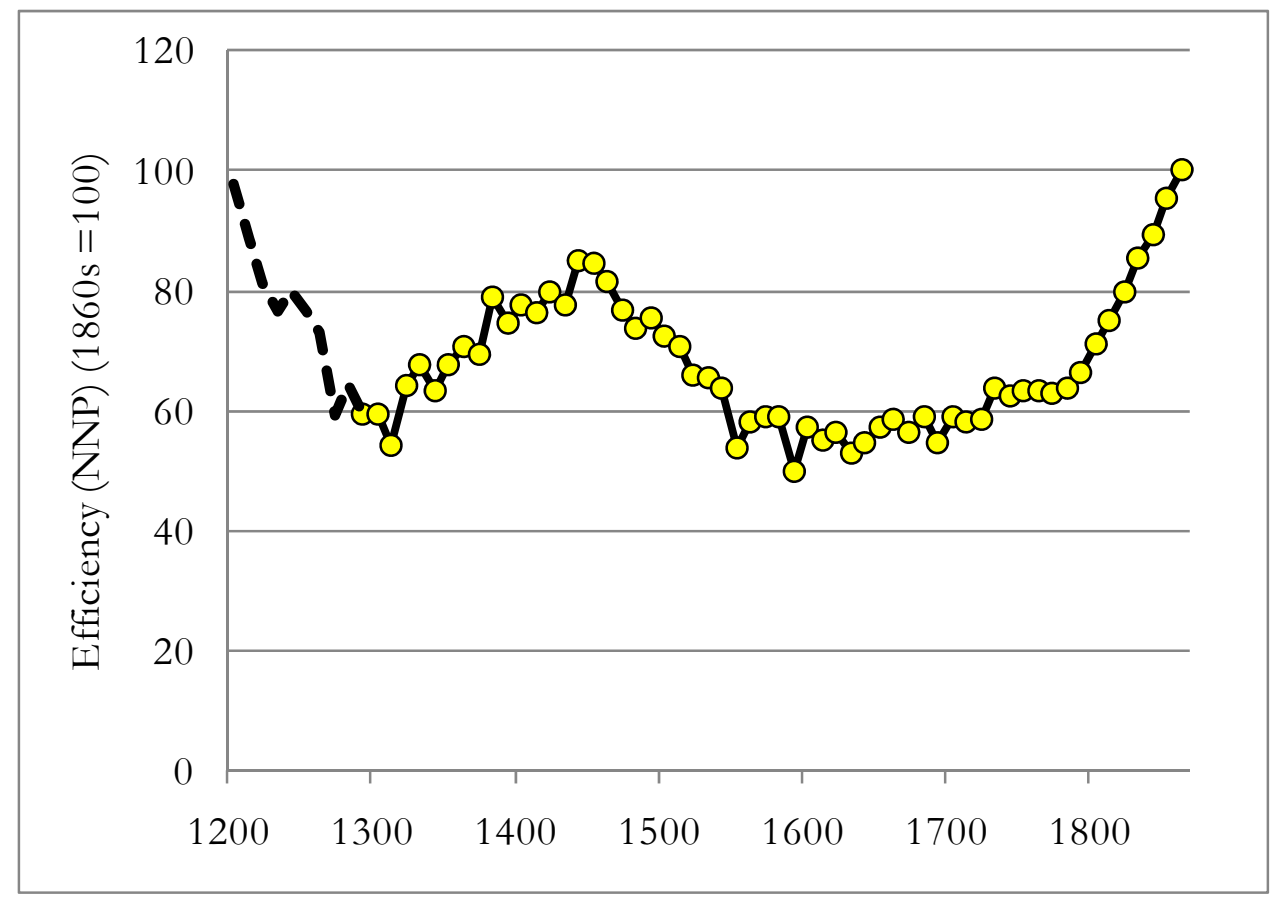


Figure 13: The Components of English Economic Efficiency Measurement, 1209-1869

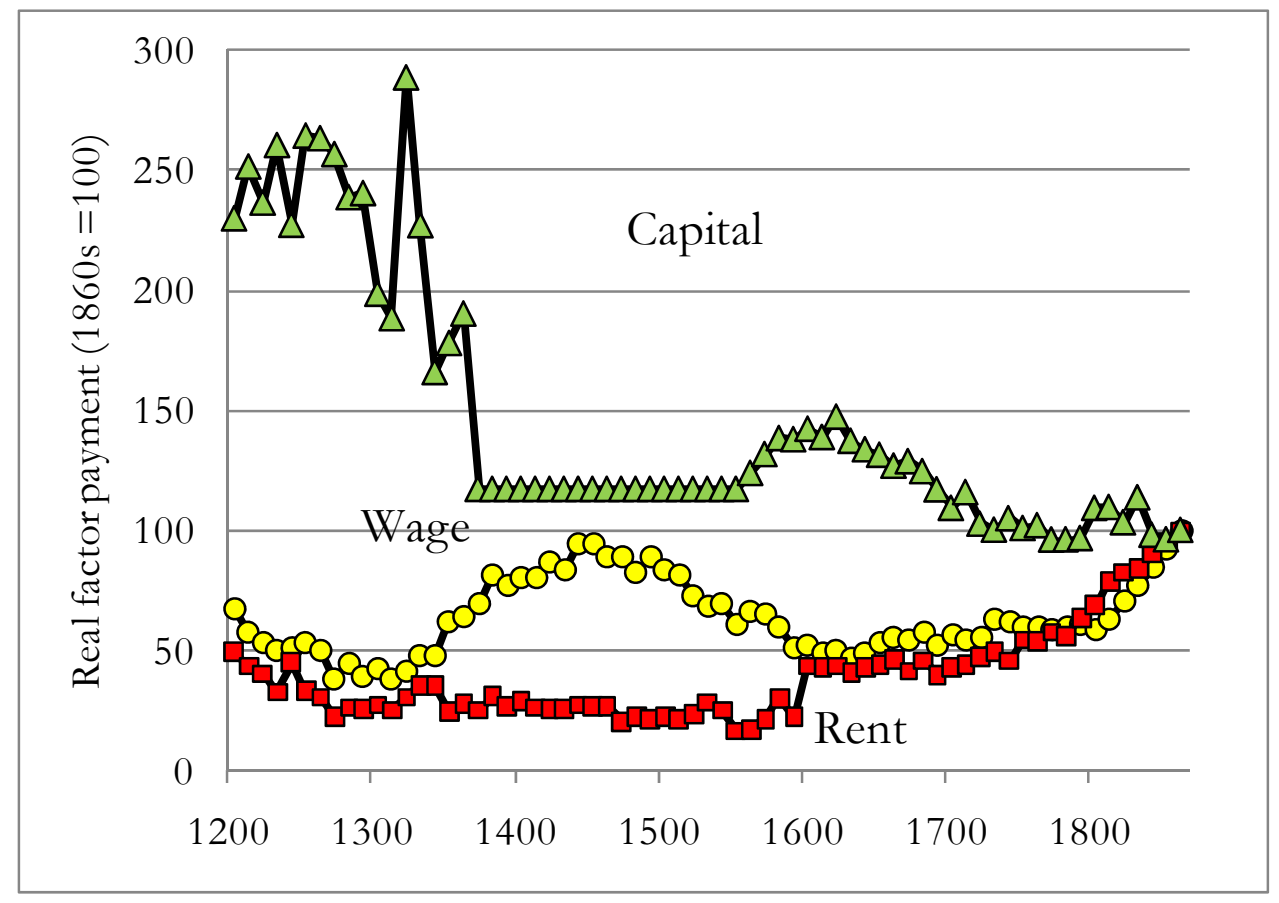

reproducible capital, then the implied productivity of the years before 1350 would be significantly smaller. Since we cannot observe directly the level of the capital stock in these years the level of efficiency in the period before 1350 thus remains uncertain, as of course does output per person.

\section{Productivity Fluctuations, 1200-1700}

One of the things that makes it very difficult to decide when the transition to modern productivity growth began is the fluctuations we observe in figures 11 and 12 in the productivity level of the pre-industrial economy. If these are measurement error, then they suggest the measure of productivity for the pre-industrial era is sufficiently poor that we will never be able to know whether there was a gradual or sudden transition to modern economic growth. If they are not measurement error, then they imply quite inexplicable fluctuations in the performance of the preindustrial economy. 
I can say for sure that the observed fluctuations in productivity are not just measurement error, but reflect real changes in the efficiency of the economy. To see this consider figure 13 . The real rental of capital was clearly falling over time, and that implies higher earlier productivity. The fluctuations in the productivity measure over the pre-industrial period are associated with the very substantial fluctuations in real wages. In 1450 real wages in England were nearly as great as they were at the end of the Industrial Revolution in the 1860s. These fluctuations in turn were highly correlated with movements in the population. There were only about 2.2 million people in England when real wages reached their medieval maximum around 1450. There were nearly 6 million people when they were at their medieval minimum in the 1310 s.

For measured productivity to remain constant over these huge population fluctuations there had to be countervailing declines in land rents. But since wages were $44-67 \%$ of estimated factor payments, even in the medieval period, the countervailing swings in rents would have to be much more substantial than those of wages in order for measured productivity to remain constant. In practice there were instead relatively modest downward movements in real rents in the periods of low population, as figure 9 shows.

Thus the fluctuations in medieval productivity do not seem attributable to measurement error, in that the wage series that is causing it is one of the best measured of all the series. Resolving this puzzle is difficult. One possible step towards a resolution would be to re-examine the assumption, underlying the generation of the factor shares in the earlier economy, that hours of labor input per person were constant from 1200 to 1869. If hours of labor input were much smaller in the medieval period, then the share of rents in total income would be higher, and the implied productivity fluctuations smaller. But the size of the hours reduction in the period of high measured efficiency necessary to eliminate the measured efficiency gains would have to be very substantial. And there is little other evidence of any substantial changes in hours worked.

\section{Output and Efficiency, 1860-2008}

In this section I link the earlier estimates of real income, real wages, and factor shares to the modern data for England. The data for 1870 and later is mainly quoted on a UK basis, meaning England, Wales, Scotland and Ireland (after 1922 Northern Ireland only). UK income is divided

into English versus other by, as before, taking the English population divided by British population plus one half of the Irish population (to allow for the lower income of Ireland). 
Real GDP per person: Feinstein gives for 1860-1920 real GDP per capita for Great Britain (Feinstein, 1972, T118-9). This series is continued for England 1920-1948 by deflating nominal GDP per person for the UK by Feinstein's GDP deflator (Feinstein, 1972, T5-9, T132-3). For 1948-2008 the Office of National Statistics reports real GDP per capita (UK, Office of National Statistics). The decadal averages for this series are reported in the second column of table 34. This is thus a continuation of the columns in table 28 giving measures of real NNI per capita and real GDP per capita for the 1860 s and earlier.

\section{TABLE 34}

Farmland rent share: Net domestic income for England 1860-2007 is calculated by reducing UK net domestic income to an English basis. Total farmland rents for England 1860-1914 are from Stamp, 1922, 49, Engand and Wales, adjusted to an English basis. This Stamp series is projected on to 1944 using the movement of UK farmland rents reported in Feinstein, 1972, T60. For 1944-2004 the Department of Environment, Food, and Rural Affairs (DEFRA), reports a series "Agricultural Land Sales and Prices in England" which gives prices per acre/hectare. This are converted into rents per acre in 1945-1967 using a return rate of 3\%, and multiplied by an assumed $28 \mathrm{~m}$. acres of farmland in England to give total rents. For 1968-2007 DEFRA reports a series on land tenancy rentals per hectare (normed to the average of Full Annual Tenancy and Farm Business Tenancy leases). Again these are multiplied by an assumed $28 \mathrm{~m}$. acres farm area to give total farm rents. The implied share of rents in national income in England are shown in table 34.

Share of Wages: Feinstein reports both wages and salaries and income from self employment for the UK 1860-1947 (Feinstein, 1972, p. T4-9). Income from self-employment is assumed throughout to be half labor income. This is divided by UK net domestic income minus expenditure taxes (less subsidies). For 1948-2008 the share of wages is calculated in the same way from the series reported by the Office of National Statistics.

Urban Site Rents: The Blue Books (Office of National Statistics) give from 1987-2007 the value for the UK of dwellings and other buildings (including and excluding the land value). From this can be inferred the capital value of urban site rents. Since site rents exhibit no depreciation these are converted into site rents by multiplying them by an assumed rate of return (excluding capital gains) of 3\% 1987-1996 (the rental return on farmland averaged only 2.8\% between 1968 and 2007). From 1996-2005 house prices in England rose by 170\%, while house rents rose by $34 \%$. If the rental return on housing was $3 \%$ in 1996, then by 2005 it was $1.5 \%$. So for these years the capitalized site 
values are converted into implicit rentals by the current implied rental on housing. This data suggests that urban site rentals represented then about $4 \%$ of total incomes (and about $45 \%$ of the value of dwellings and other buildings).

Singer (1941) estimates urban site values in England and Wales, 1845-1910 from the movement of construction costs versus tax assessments. The weakness in this estimate, however is that he has to make an assumption about the share of site rents in property rentals in 1845, which he assumes then is only $8.2 \%$ of building rents. This gives site rents $1860-1910$.

Site rents 1947-1986 are estimated from the relative movement of the total average house values (constructed as number of households $\times$ average house price) compared to the average value of the reproducible housing capital stock reported by the Office of National Statistics. The house price series continues back to 1930. It is used to project site values back to then by assuming the same proportion of house values were site rents throughout the 1930-1947 period.

Share of Capital: This was constructed as a residual so that the shares of land, labor, urban site rents and capital summed to 1.

Real Wage and Skill Premium: The real wage series here is that of Clark (2005), and covers an average of building workers and craftsmen. Real wages are calculated as the average of nominal wages per 10 hours for building trademen and for building laborers, deflated by Feinstein's cost of living index (until 1993) (Feinstein, 1995), and thereafter by the retail price index from the Office of National Statistics. The skill premium is the differential of the wage of craftsmen to workers.

Economic Efficiency: The decline of land rents to a tiny share of national income since 1860, and the relative constancy of the rate of return on capital, mean that the equation (1) for calculating economic efficiency since 1860 reduces to the simple expression,

$$
\approx \frac{1}{\left(1-\tau_{t}\right)}\left[\frac{w_{t}}{P_{t}}\right]^{b}
$$

The last column of table 34 gives this simple measure of economic efficiency by decade from the 1860 s to the 2000 s, with the 1860 s set at 100 . Because the magnitude of $b$ varies over time between 0.65 and 0.80 the index is constructed by periodically changing the weights periodically and chaining the resulting indices. This is a continuation of the efficiency indices constructed in table 33 . Figure 14 shows the picture of the efficiency of the English economy from the 1200 s to the 2000 s. 
Figure 14: National Productivity, England, 1209-2004

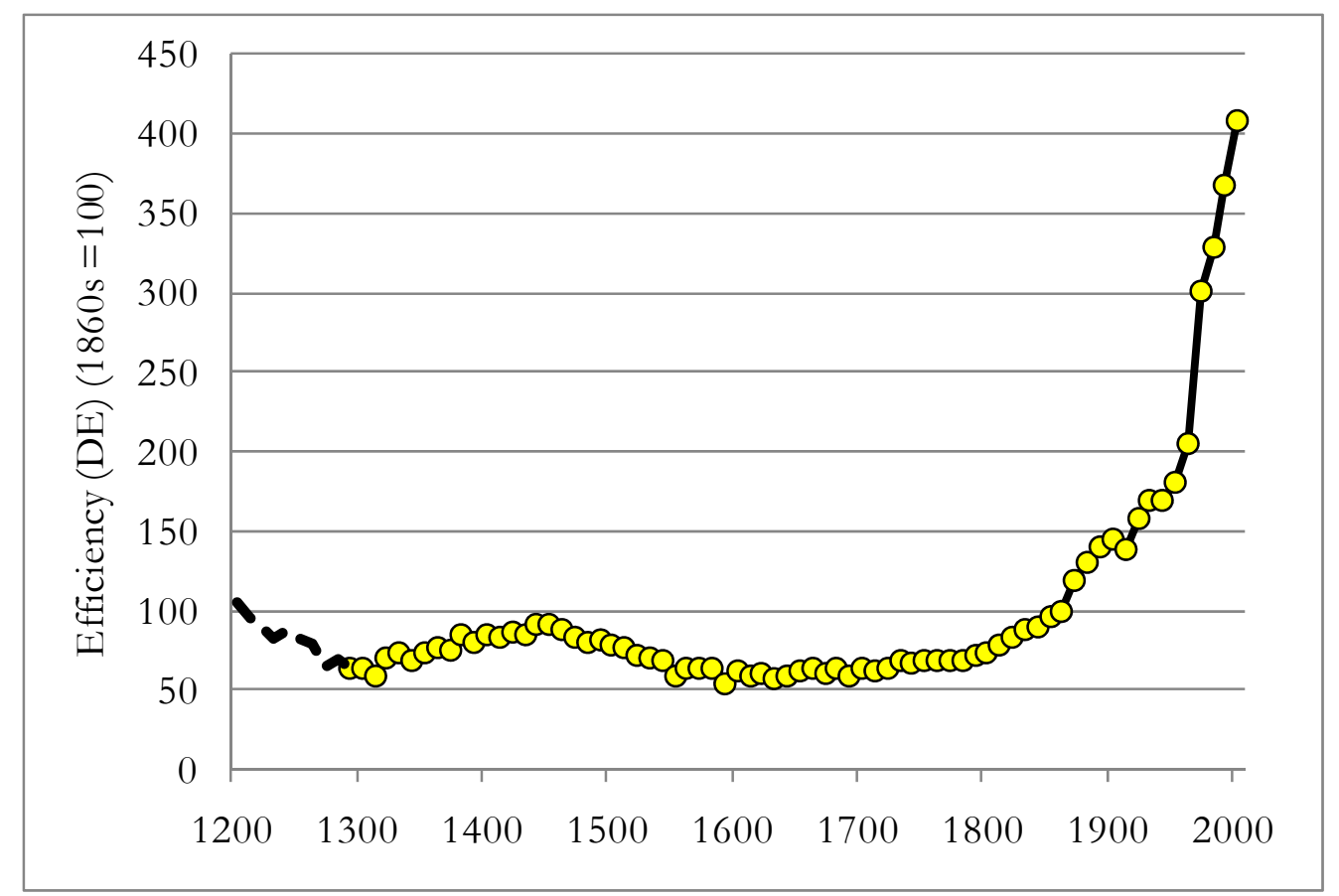

Figure 14 shows why just with the data on economic growth and economic efficiency it is not possible to assign any definitive moment to the Industrial Revolution. There was a gradual increase in the rate of growth of economic efficiency, and hence also of output per person. But was 1600 the start of this process? Or 1800 ? 


\section{Bibliography}

Albert, W. 1972. The Turnpike Road System in England 1663-1840. Cambridge: Cambridge University Press.

Allen, Robert C. 2008. "Review of A Farewell to Alms." Journal of Economic Literature.

Barney, John M. 1999. "Shipping in the Port of King's Lynn, 1702-1800" Journal of Transport History, 20(2): 126-140.

Bogart, Dan. 2005. "Did Turnpike Trusts Increase Transportation Investment in EighteenthCentury England." Journal of Economic History, 65(June): 439-468.

Bowley, A. L. 1898. "The Statistics of Wages in the United Kingdom during the last Hundred Years. Part I. Agricultural Wages," Journal of the Royal Statistical Society, 61: 702-722.

Broadberry, Stephen, Bruce Campbell, et al. 2009. "British Economic Growth, 1300-1850: Some Preliminary Estimates." University of Warwick.

Clark, Gregory. 2007a. "The Long March of History: Farm Wages, Population and Economic Growth, England 1209-1869" Economic History Review.

Clark, Gregory. 2007b. A Farewell to Alms: A Brief Economic History of the World. Princeton: Princeton University Press.

Clark, Gregory. 2005. "The Condition of the Working-Class in England, 1209-2004” Journal of Political Economy, 113(6) (December, 2005): 1307-1340.

Clark, Gregory. 2002a. "Farmland Rental Values and Agrarian History: England and Wales, 15001912" European Review of Economic History, 6(3) (December 2002): 281-309.

Clark, Gregory. 2002b. "Shelter from the Storm: Housing and the Industrial Revolution, 15501912" Journal of Economic History, 62(2) (June 2002).

Clark, Gregory. 2001a. "Farm wages and living standards in the Industrial Revolution: England, 1670-1869.” Economic History Review.

Clark, Gregory. 2001b. "Markets and Economic Growth: The Grain Market of Medieval England.” Working Paper, UC-Davis.

Clark, Gregory. 1998a. "Land Hunger: Land as a Commodity and as a Status Good in England, 1500-1910," Explorations in Economic History, 35(1) (January): 59-82.

Clark, Gregory. 1998b. "The Reports of the Charity Commission as a Source in Economic History." Research in Economic History 18.

Clark, Gregory. 1996. "The Political Foundations of Modern Economic Growth: England, 15401800," Journal of Interdisciplinary History, 26 (Spring): 563-588.

Clark, Gregory. 1988. "The Cost of Capital and Medieval Agricultural Technique," Explorations in Economic History, 25 (July): 265-294.

Clark, Gregory, Michael Huberman and Peter Lindert. 1995. “A British Food Puzzle, 1770-1850," Economic History Review, 48(2): 215-237.

Clark, Gregory and Patricia Levin. 2001. "How different was the Industrial Revolution? The Revolution in Printing, 1350-1869.” Working Paper, University of California, Davis. 
Clark, Gregory and Van Der Werf, Ysbrand. 1998. "Work in Progress? The Industrious Revolution". Journal of Economic History 58 (3): 830-843.

Chubb, Harry. 1876. "The Supply of Gas to the Metropolis." Journal of the Statistical Society of London, Vol. 39, No. 2 (Jun): 350-380

Crafts, N. F. R. 1985. British Economic Growth During the Industrial Revolution. New York: Oxford University Press.

Crafts, N.F.R., and C. K. Harley. 1992. "Output Growth and the Industrial Revolution: A Restatement of the Crafts-Harley View." Economic History Review 45:703-730.

Deane, Phyllis, and W. A. Cole. 1967. British Economic Growth, 1688-1959. 2d ed. Cambridge: Cambridge University Press.

Davis, Ralph. 1956. “Seamen's Sixpences: An Index of Commercial Activity, 1697-1828” Economica, 23(92): 328-43.

Davis, Ralph. 1957. "Earnings of Capital in the English Shipping Industry, 1670-1730" Journal of Economic History, 17(3): 409-25.

Davis, Ralph. 1962. "English Foreign Trade, 1700-1774” Economic History Review, 15(2): 285-303.

Davis, Ralph. 1979. The Industrial Revolution and British Overseas Trade. Leicester: Leicester University Press.

De Vries, Jan. 1994. “The Industrial Revolution and the Industrious Revolution." Journal of Economic History, 54: 249-270.

De Vries, Jan and Ad van der Woude. 1997. The first modern economy : success, failure, and perseverance of the Dutch economy, 1500-1815. Cambridge: Cambridge University Press.

De Vries, Jan. 2000. "Dutch Economic Growth in Comparative Historical Perspective, 1500-2000. De Economist, 148 (4): 443-467.

De Vries, Jan. 2008. The Industrious Revolution: Consumer Behavior and the Household Economy, 1650 to the Present. Cambridge: Cambridge University Press.

Dietz, Frederick C. 1921. English Government Finance, 1485-1558. New York: Barnes and Noble.

Dietz, Frederick C. 1932. English Government Finance, 1558-1641. New York: Barnes and Noble.

Dyer, Christopher. 1988. "Changes in Diet in the Late Middle Ages: the Case of Harvest Workers." Agricultural History Review, 36(1): 21-37.

Falkus, M. E. 1982. “The Early Development of the British Gas Industry, 1790-1815.” Economic History Review, New Series, Vol. 35, No. 2 (May): 217-234.

Feinstein, Charles H. 1972. National Income, Expenditure and Output of the United Kingdom, 1855-1965. Cambridge: Cambridge University Press.

Feinstein, Charles H. 1988. "National Statistics, 1760-1920" in Charles H. Feinstein and Sidney Pollard, Studies in Capital Formation in the United Kingdom, 1750-1920. Oxford: Clarendon Press, 258-404. 
Feinstein, Charles H. 1995. "Changes in Nominal Wages, the Cost of Living and Real Wages in the United Kingdom over Two Centuries.” in P Scholliers and V. Zamagni (eds.), Labour's Reward: Real Wages and Economic Change in $19^{\text {th }}$ and 20 ${ }^{\text {th }}$-Century Europe. Aldershot, Hants: Edward Elgar.

Feinstein, Charles H. 1998a. "Pessimism Perpetuated: Real Wages and the Standard of Living in Britain During and After the Industrial Revolution." Journal of Economic History, 58 (3) (Sept.), 625-658.

Feinstein, Charles H. 1998b. "Wage-Earnings in Great Britain during the Industrial Revolution." In Iain Begg and S. G. B. Henry, Applied Economics and Public Policy. Cambridge: Cambridge University Press.

Flinn, Michael W. 1984. The History of the British Coal Industry. Vol. 2,1700-1830. Oxford. Clarendon Press.

Ginarlis, John and Sidney Pollard. 1988. "Roads and Waterways, 1750-1850." In Charles H. Feinstein and Sidney Pollard, Studies in Capital Formation in the United Kingdom, 1750-1920. Oxford: Clarendon Press, 182-224.

Grimwade, M. E. 1979. Index of the Probate Records of the Court of the Archdeacon of Suffolk, 1444-1700. London: The British Record Society.

Graham, Gerald S. 1956. "The Ascendancy of the Sailing Ship 1850-85" Economic History Review, New Series, 9(1): 74-88.

Harley, Knick. 1988. “Ocean Freight Rates and Productivity, 1740-1913: The Primacy of Mechanical Invention Reaffirmed” Journal of Economic History, 48(4) (Dec.):851-76.

Harley, Knick. 1993. "Reassessing the Industrial Revolution: A Macro View," in Joel Mokyr (ed.), The British Industrial Revolution: An Economic Assessment (Boulder, Colorado: Westview Press, 1993), 227-266.

Harley, Knick. 1997. "Cotton Textile Prices and the Industrial Revolution," Working Paper, University of Western Ontario, February 1997.

Harris, G. L. 1975. King, Parliament, and Public Finance in Medieval England to 1369. Oxford: Clarendon Press.

Hatcher, John. 1993. The History of the British Coal Industry, Vol. 1, Before 1700: Towards the Age of Coal. Oxford: Clarendon Press.

Jastram, Roy W. 1981. Silver: The Restless Metal. New York: John Wiley and Sons.

Levi, Leone. 1867. Wages and Earnings of the Working Classes. London: John Murray.

Lindert, Peter H. 1980. "English Occupations, 1670-1811." Journal of Economic History 40:685-712.

Matthews, Derek. 1986. "Laissez-faire and the London Gas Industry in the Nineteenth Century: Another Look." The Economic History Review, New Series, 39(2) (May): 244-263 
Matthews, William. 1832. An historical sketch of the origin and progress of gas-lighting. London: Simpkin and Marshall.

Mitchell, B. R. and Phyllis Deane. 1971. Abstract of British Historical Statistics. Cambridge: Cambridge University Press.

Mitchell, B. R. 1988. British Historical Statistics. Cambridge: Cambridge University Press.

Mulhall, Michael G. 1899. The Dictionary of Statistics. London: Routledge.

Parliamentary Papers. 1803-4. Report from the Committee on the London Bakers Petition.

Parliamentary Papers. 1812-13. Report from the Committee on the Petition of Certain County Bakers.

Parliamentary Papers. 1852-3. 1851 Census. Ages, Civil Conditions Occupations and Birthplaces. Part I.

Vol. lxxxviii Part I, 1.

Pawson, Eric. 1977. Transport and Economy: The Turnpike Roads of Eighteenth Century Britain. London: Academic Press.

Pollard, Sydney. 1988. "The Insurance Policies" in in Charles H. Feinstein and Sidney Pollard, Studies in Capital Formation in the United Kingdom, 1750-1920. Oxford: Clarendon Press, 225257.

Prados de la Escosura , Leandro. 2000. "International Comparisons of Real Product, 1820-1990: An Alternative Data Set” Explorations in Economic History, 37(1): 1-41.

Shaw-Taylor, Leigh and E.A. Wrigley. 2008. "The Occupational Structure of England c. 1750-1871: A Preliminary Report." Cambridge, England: Cambridge Group for the History of Population and Social Structure.

Singer, H. W. 1941. "An Index of Urban Land Rents and House Rents in England and Wales, 1845-1913" Econometrica, 9(3/4): 221-230

Smits, Jan-Pieter, Edwin Horlings, and Jan Luiten van Zanden. 1999. Dutch GNP and Its Components, 1800-1913. Groningen Growth and Development Center, Monograph Series, \#5.

Stamp, Josiah. 1922. British Incomes and Property. London: King and Son.

Squarey, Elias P. 1878. "Farm Capital" Journal of the Royal Agricultural Society of England, Second Series, 14, 425-444.

Terry, Schuyler B. 1914. The Financing of the Hundred Years' War, 1337-1360. London: Constable and Co.

Tomson, James. 1847. "Acount of Hall Farm, near Sevenoaks, Kent." Journal of the Royal Agricultural Society of England, 8, 33-46.

Ville, Simon P. 1990. English shipowning during the industrial revolution: Michael Henley and Son, London Shipowners, 1770-1830. Manchester: Manchester University Press.

Voth, Hans-Joachim. 2001a. Time and Work in England, 1750-1830. Oxford: Oxford University Press. Voth, Hans-Joachim. 2001b. "The Longest Years: New Estimates of Labor Input in England, 1760-1830.” Journal of Economic History, 61(4): 1065-82. 
Wratislaw, Charles. 1861. “The Amount of Capital Required for the Profitable Operation of a Mixed Arable and Pasture Farm in a Midland County." Journal of the Royal Agricultural Society of England, Second Series, 14, 425-444.

Wrigley, E. A. 1985. "Urban Growth and Agricultural Change: England and the Continent in the Early Modern Period." Journal of Interdisciplinary History 15:683-728.

Wrigley, E. A., R. S. Davies, J. E. Oeppen, and R. S. Schofield. 1997. English Population History from Family Reconstruction: 1580-1837. Cambridge; New York: Cambridge University Press. 
Table 1: Wages, 1200s-1860s

\begin{tabular}{|c|c|c|c|c|c|c|}
\hline Decade & $\begin{array}{c}\text { Farm } \\
\text { Wages } \\
\text { (d./day) }\end{array}$ & $\begin{array}{c}\text { Building } \\
\text { Laborers } \\
\text { (d./day) }\end{array}$ & $\begin{array}{l}\text { Building } \\
\text { Craftsmen } \\
\text { (d./day) }\end{array}$ & $\begin{array}{c}\text { Share in } \\
\text { Primary } \\
\text { Production }\end{array}$ & $\begin{array}{c}\text { Average } \\
\text { Wage } \\
\text { (d./day) }\end{array}$ & $\begin{array}{c}\text { Skill } \\
\text { Premium } \\
\text { (craft/labor) }\end{array}$ \\
\hline 1200 & 1.37 & - & 2.78 & 0.60 & 2.02 & - \\
\hline 1210 & 1.26 & - & 2.08 & 0.60 & 1.97 & - \\
\hline 1220 & 1.25 & 1.63 & 2.60 & 0.60 & 1.96 & 1.56 \\
\hline 1230 & 1.18 & - & - & 0.60 & 1.88 & - \\
\hline 1240 & 1.25 & 1.88 & 2.89 & 0.60 & 2.03 & 1.92 \\
\hline 1250 & 1.31 & 1.71 & 3.17 & 0.60 & 2.12 & 1.93 \\
\hline 1260 & 1.33 & 1.77 & 3.10 & 0.60 & 2.15 & 1.86 \\
\hline 1270 & 1.28 & 1.45 & 2.70 & 0.60 & 1.94 & 1.89 \\
\hline 1280 & 1.35 & 1.43 & 2.84 & 0.60 & 2.02 & 2.00 \\
\hline 1290 & 1.32 & 1.42 & 2.83 & 0.60 & 2.00 & 2.01 \\
\hline 1300 & 1.34 & 1.57 & 3.01 & 0.60 & 2.09 & 1.93 \\
\hline 1310 & 1.44 & 1.73 & 3.27 & 0.60 & 2.26 & 1.90 \\
\hline 1320 & 1.54 & 1.67 & 3.23 & 0.60 & 2.31 & 1.95 \\
\hline 1330 & 1.52 & 1.70 & 3.26 & 0.60 & 2.31 & 1.92 \\
\hline 1340 & 1.49 & 1.61 & 2.89 & 0.60 & 2.18 & 1.80 \\
\hline 1350 & 2.80 & 2.28 & 4.06 & 0.60 & 3.61 & 1.79 \\
\hline 1360 & 2.88 & 2.75 & 4.45 & 0.60 & 3.87 & 1.63 \\
\hline 1370 & 3.16 & 2.94 & 4.72 & 0.60 & 4.19 & 1.61 \\
\hline 1380 & 3.17 & 2.95 & 4.62 & 0.60 & 4.17 & 1.57 \\
\hline 1390 & 3.05 & 2.88 & 4.56 & 0.60 & 4.05 & 1.59 \\
\hline 1400 & 3.45 & 3.15 & 4.72 & 0.60 & 4.46 & 1.50 \\
\hline 1410 & 3.47 & 3.17 & 4.89 & 0.60 & 4.52 & 1.55 \\
\hline 1420 & 3.50 & 3.31 & 4.96 & 0.60 & 4.59 & 1.50 \\
\hline 1430 & 3.68 & 3.43 & 5.06 & 0.60 & 4.77 & 1.48 \\
\hline 1440 & 3.66 & 3.54 & 5.29 & 0.60 & 4.84 & 1.50 \\
\hline 1450 & 3.79 & 3.62 & 5.19 & 0.60 & 4.94 & 1.44 \\
\hline 1460 & 3.54 & 3.59 & 5.03 & 0.60 & 4.70 & 1.40 \\
\hline 1470 & 3.56 & 3.45 & 5.13 & 0.60 & 4.72 & 1.49 \\
\hline 1480 & 3.53 & 3.45 & 4.99 & 0.60 & 4.65 & 1.45 \\
\hline 1490 & 3.52 & 3.43 & 5.09 & 0.60 & 4.70 & 1.49 \\
\hline 1500 & 3.38 & 3.36 & 4.93 & 0.60 & 4.50 & 1.47 \\
\hline 1510 & 3.37 & 3.47 & 5.12 & 0.60 & 4.57 & 1.48 \\
\hline 1520 & 3.42 & 3.48 & 5.29 & 0.60 & 4.64 & 1.52 \\
\hline 1530 & 3.32 & 3.64 & 5.45 & 0.60 & 4.65 & 1.50 \\
\hline 1540 & 3.94 & 4.04 & 5.78 & 0.60 & 5.29 & 1.43 \\
\hline
\end{tabular}


Table 1: Wages, 1200s-1860s (cont.)

\begin{tabular}{|c|c|c|c|c|c|c|}
\hline Decade & $\begin{array}{c}\text { Farm } \\
\text { Wages } \\
\text { (d./day) }\end{array}$ & $\begin{array}{l}\text { Building } \\
\text { Laborers } \\
\text { (d./day) }\end{array}$ & $\begin{array}{l}\text { Building } \\
\text { Craftsmen } \\
\text { (d./day) }\end{array}$ & $\begin{array}{c}\text { Share in } \\
\text { Primary } \\
\text { Production }\end{array}$ & $\begin{array}{c}\text { Average } \\
\text { Wage } \\
\text { (d./day) }\end{array}$ & $\begin{array}{c}\text { Skill } \\
\text { Premium } \\
\text { (craft/labor) }\end{array}$ \\
\hline 1550 & 5.06 & 5.23 & 7.62 & 0.60 & 6.84 & 1.46 \\
\hline 1560 & 6.15 & 6.10 & 8.63 & 0.60 & 8.12 & 1.42 \\
\hline 1570 & 6.64 & 6.42 & 9.06 & 0.60 & 8.66 & 1.42 \\
\hline 1580 & 6.67 & 6.67 & 9.76 & 0.60 & 8.90 & 1.47 \\
\hline 1590 & 7.13 & 6.76 & 10.0 & 0.60 & 9.33 & 1.48 \\
\hline 1600 & 7.52 & 7.61 & 10.9 & 0.60 & 10.0 & 1.44 \\
\hline 1610 & 7.97 & 8.03 & 12.0 & 0.60 & 10.7 & 1.49 \\
\hline 1620 & 8.31 & 8.24 & 12.5 & 0.60 & 11.2 & 1.51 \\
\hline 1630 & 8.93 & 9.07 & 13.3 & 0.60 & 12.0 & 1.47 \\
\hline 1640 & 9.36 & 10.0 & 15.0 & 0.60 & 12.9 & 1.50 \\
\hline 1650 & 10.1 & 11.1 & 16.6 & 0.60 & 14.1 & 1.50 \\
\hline 1660 & 10.6 & 11.5 & 17.6 & 0.60 & 14.8 & 1.53 \\
\hline 1670 & 9.84 & 12.0 & 17.7 & 0.60 & 14.4 & 1.48 \\
\hline 1680 & 9.89 & 12.2 & 17.8 & 0.59 & 14.6 & 1.46 \\
\hline 1690 & 9.62 & 12.3 & 18.5 & 0.57 & 14.6 & 1.50 \\
\hline 1700 & 9.81 & 11.9 & 19.0 & 0.56 & 14.9 & 1.60 \\
\hline 1710 & 10.0 & 12.1 & 19.7 & 0.54 & 15.4 & 1.63 \\
\hline 1720 & 9.84 & 12.4 & 20.0 & 0.52 & 15.5 & 1.62 \\
\hline 1730 & 10.8 & 12.6 & 20.3 & 0.51 & 16.4 & 1.62 \\
\hline 1740 & 10.6 & 12.6 & 20.6 & 0.49 & 16.4 & 1.63 \\
\hline 1750 & 10.9 & 13.1 & 20.5 & 0.47 & 16.8 & 1.57 \\
\hline 1760 & 11.5 & 13.9 & 21.3 & 0.46 & 17.8 & 1.53 \\
\hline 1770 & 12.3 & 15.1 & 22.3 & 0.45 & 19.0 & 1.48 \\
\hline 1780 & 13.1 & 15.3 & 23.4 & 0.45 & 19.9 & 1.53 \\
\hline 1790 & 15.3 & 17.9 & 26.8 & 0.44 & 23.1 & 1.50 \\
\hline 1800 & 19.4 & 23.9 & 35.9 & 0.43 & 30.4 & 1.51 \\
\hline 1810 & 23.1 & 29.8 & 43.8 & 0.42 & 37.1 & 1.47 \\
\hline 1820 & 20.3 & 27.0 & 42.1 & 0.40 & 34.4 & 1.56 \\
\hline 1830 & 20.0 & 28.0 & 42.7 & 0.38 & 35.2 & 1.53 \\
\hline 1840 & 21.1 & 29.0 & 43.3 & 0.36 & 36.7 & 1.50 \\
\hline 1850 & 22.1 & 30.1 & 45.6 & 0.32 & 38.9 & 1.52 \\
\hline 1860 & 23.6 & 34.5 & 52.7 & 0.28 & 45.0 & 1.53 \\
\hline
\end{tabular}


Table 2: Assumed sectoral employment distribution

\begin{tabular}{|c|c|c|c|c|}
\hline Year & \multicolumn{2}{|c|}{$\begin{array}{l}\text { Share primary } \\
\text { sector assumed } \\
\text { here }\end{array}$} & $\begin{array}{l}\text { Broadberry et al. } \\
\text { (Agricultural } \\
\text { Population) }\end{array}$ & $\begin{array}{l}\text { Share in Wills } \\
\text { (primary sector) }\end{array}$ \\
\hline 1851 & & .34 & - & 0.36 \\
\hline 1817 & & .42 & - & 0.44 \\
\hline 1755 & & .47 & - & 0.45 \\
\hline 1700 & & .48 & .54 & 0.48 \\
\hline 1680 & & .50 & - & 0.50 \\
\hline 1600 & & .60 & .70 & 0.60 \\
\hline $1560 / 70$ & & .60 & - & 0.60 \\
\hline $1520 / 30$ & & .60 & .75 & - \\
\hline 1380 & & .60 & .76 & - \\
\hline 1300 & & .60 & .79 & - \\
\hline \multirow{2}{*}{\multicolumn{5}{|c|}{$\begin{array}{l}\text { Notes: Broadberry et al. (2009), table 18, S1 } \\
\text { Table 3: Labor Income } 1866 \text { from Levi }\end{array}$}} \\
\hline & & & & \\
\hline Category & $\begin{array}{l}\text { Number } \\
1860-9(\mathrm{~m})\end{array}$ & $\begin{array}{l}\text { Wage per day, } \\
1866 \text { (d.) }\end{array}$ & $\begin{array}{c}\text { Male- } \\
\text { Equivalents }\end{array}$ & $\begin{array}{c}\text { Total } \\
\text { Earnings, } \\
1866(£ \mathrm{~m} .)\end{array}$ \\
\hline Men 20-64 & 5.37 & 45 & 1.00 & 302 \\
\hline Men, $<20$ & 1.36 & 13 & 0.29 & 22 \\
\hline Women 20-64 & 2.45 & 25 & 0.56 & 77 \\
\hline Women $<20$ & 0.90 & 17 & 0.38 & 19 \\
\hline All & 10.08 & 32.1 & 0.71 & 420 \\
\hline
\end{tabular}


Table 4: Alternative population estimates, England, 1300-1600

\begin{tabular}{cccc}
\hline Year & $\begin{array}{c}\text { Broadberry et al. } \\
\text { population (m.) }\end{array}$ & $\begin{array}{c}\text { Clark (2007a) } \\
\text { population (m.) }\end{array}$ & Ratio \\
\hline 1300 & 4.25 & 5.32 & 1.25 \\
1348 & 3.83 & 4.48 & 1.17 \\
1351 & 2.56 & 3.54 & 1.38 \\
1380 & 2.37 & 2.98 & 1.26 \\
1520 & 2.20 & 2.87 & 1.30 \\
1600 & 4.12 & 4.28 & 1.04 \\
\hline
\end{tabular}

Sources: Broadberry, Campbell et al. (2009), table 18.

Table 5: Broadberry et al.'s assumptions about farm labor inputs

\begin{tabular}{lcccc}
\hline Date & $\begin{array}{c}\text { Assumed work } \\
\text { days per farm } \\
\text { family }\end{array}$ & $\begin{array}{c}\text { Farm families } \\
(\mathrm{m} .)\end{array}$ & $\begin{array}{c}\text { Farm output } \\
\text { (index) }\end{array}$ & $\begin{array}{c}\text { Output per } \\
\text { work day } \\
\text { (index) }\end{array}$ \\
\hline & & & & \\
1250 & 315 & 0.68 & 1.00 & 1.00 \\
1300 & 381 & 0.74 & 1.17 & 0.89 \\
1380 & 331 & 0.40 & 1.07 & 1.72 \\
1450 & 266 & 0.38 & 0.94 & 1.97 \\
1600 & 404 & 0.64 & 1.51 & 1.25 \\
1700 & 405 & 0.62 & 2.18 & 1.86 \\
1800 & 473 & 0.69 & 2.52 & 1.64 \\
1850 & 539 & 0.73 & 4.66 & 2.51 \\
& & & & \\
\hline
\end{tabular}

Sources: Broadberry, Campbell et al. (2009), table 24. 
Table 6: Implied Days Worked Per Year

\begin{tabular}{llll}
\hline Period & Observations & Implied Days & Standard \\
& per year & Error of \\
& & Estimate
\end{tabular}

\begin{tabular}{llll}
\hline & & & \\
1867-9, England & 7 & 311 & 13.4 \\
1867-9, Wales & 5 & 280 & 5.9 \\
1870, Scotland ${ }^{\text {a }}$ & 27 & 280 & 12.9 \\
1771, England & 10 & 295 & 12.9 \\
1733-6, Norfolk & 24 & 286 & 4.6 \\
1700-32, England & 3 & 276 & 13.7 \\
1650-99, England & 16 & 266 & 6.5 \\
1600-49, England & 12 & 257 & 5.9 \\
1560-99, England & 17 & 4.8 \\
\end{tabular}


Table 7: Population, Labor Income, Taxes, Rents, Capital Returns

\begin{tabular}{|c|c|c|c|c|c|c|}
\hline Decade & $\begin{array}{l}\text { Population } \\
\text { (m.) }\end{array}$ & $\begin{array}{c}\text { Labor } \\
\text { Income } \\
(f, \mathrm{~m})\end{array}$ & $\begin{array}{l}\text { Local rates } \\
\qquad(£, \mathrm{~m} .)\end{array}$ & $\begin{array}{l}\text { Commodity } \\
\text { Taxes } \\
(£ \mathrm{~m} .)\end{array}$ & $\begin{array}{c}\text { Farmland } \\
\text { Rents } \\
(f, \mathrm{~m})\end{array}$ & $\begin{array}{l}\text { Return on } \\
\text { Capital (\%) }\end{array}$ \\
\hline 1200 & 3.16 & 2.84 & 0.0 & 0.0 & 1.61 & 9.8 \\
\hline 1210 & 3.40 & 2.98 & 0.0 & 0.0 & 1.61 & 10.7 \\
\hline 1220 & 3.74 & 3.26 & 0.0 & 0.0 & 1.63 & 10.1 \\
\hline 1230 & 3.90 & 3.25 & 0.0 & 0.0 & 1.33 & 11.1 \\
\hline 1240 & 3.87 & 3.48 & 0.0 & 0.0 & 1.89 & 9.7 \\
\hline 1250 & 3.84 & 3.62 & 0.0 & 0.0 & 1.42 & 11.3 \\
\hline 1260 & 4.31 & 4.12 & 0.0 & 0.0 & 1.41 & 11.2 \\
\hline 1270 & 4.87 & 4.19 & 0.0 & 0.0 & 1.23 & 11.0 \\
\hline 1280 & 4.88 & 4.38 & 0.0 & 0.0 & 1.28 & 10.2 \\
\hline 1290 & 5.32 & 4.72 & 0.0 & 0.0 & 1.40 & 10.3 \\
\hline 1300 & 5.32 & 4.93 & 0.0 & 0.0 & 1.45 & 8.5 \\
\hline 1310 & 5.61 & 5.61 & 0.0 & 0.0 & 1.62 & 8.0 \\
\hline 1320 & 4.97 & 5.10 & 0.0 & 0.0 & 1.81 & 12.3 \\
\hline 1330 & 4.68 & 4.80 & 0.0 & 0.0 & 1.86 & 9.7 \\
\hline 1340 & 4.39 & 4.25 & 0.0 & 0.0 & 1.75 & 7.1 \\
\hline 1350 & 3.54 & 5.68 & 0.0 & 0.0 & 1.55 & 7.6 \\
\hline 1360 & 3.17 & 5.45 & 0.0 & 0.0 & 1.80 & 8.1 \\
\hline 1370 & 3.16 & 5.89 & 0.0 & 0.0 & 1.63 & 5.0 \\
\hline 1380 & 2.81 & 5.21 & 0.0 & 0.0 & 1.72 & 5.0 \\
\hline 1390 & 2.82 & 5.07 & 0.0 & 0.0 & 1.53 & 5.0 \\
\hline 1400 & 2.64 & 5.23 & 0.0 & 0.0 & 1.71 & 5.0 \\
\hline 1410 & 2.54 & 5.10 & 0.0 & 0.0 & 1.59 & 5.0 \\
\hline 1420 & 2.47 & 5.03 & 0.0 & 0.0 & 1.47 & 5.0 \\
\hline 1430 & 2.51 & 5.32 & 0.0 & 0.0 & 1.59 & 5.0 \\
\hline 1440 & 2.27 & 4.89 & 0.0 & 0.0 & 1.50 & 5.0 \\
\hline 1450 & 2.28 & 5.00 & 0.0 & 0.0 & 1.51 & 5.0 \\
\hline 1460 & 2.32 & 4.85 & 0.0 & 0.0 & 1.53 & 5.0 \\
\hline 1470 & 2.38 & 4.99 & 0.0 & 0.0 & 1.18 & 5.0 \\
\hline 1480 & 2.40 & 4.96 & 0.0 & 0.0 & 1.35 & 5.0 \\
\hline 1490 & 2.31 & 4.84 & 0.0 & 0.0 & 1.21 & 5.0 \\
\hline 1500 & 2.56 & 5.12 & 0.0 & 0.0 & 1.32 & 5.0 \\
\hline 1510 & 2.81 & 5.69 & 0.0 & 0.0 & 1.27 & 5.0 \\
\hline 1520 & 2.94 & 6.07 & 0.0 & 0.0 & 1.60 & 5.0 \\
\hline 1530 & 3.02 & 6.23 & 0.0 & 0.0 & 2.08 & 5.0 \\
\hline 1540 & 2.99 & 7.03 & 0.0 & 0.0 & 2.05 & 5.0 \\
\hline
\end{tabular}


Table 7 (cont.): Population, Labor Income, Taxes, Rents, Capital Returns

\begin{tabular}{|c|c|c|c|c|c|c|}
\hline Decade & $\begin{array}{l}\text { Population } \\
\text { (m.) }\end{array}$ & $\begin{array}{c}\text { Labor } \\
\text { Income } \\
(f, \mathrm{~m})\end{array}$ & $\begin{array}{l}\text { Local rates } \\
\quad(£, \mathrm{~m} .)\end{array}$ & $\begin{array}{l}\text { Commodity } \\
\text { Taxes } \\
(£, \mathrm{~m} .)\end{array}$ & $\begin{array}{l}\text { Farmland } \\
\text { Rents } \\
(f \mathrm{~m})\end{array}$ & $\begin{array}{l}\text { Return on } \\
\text { Capital (\%) }\end{array}$ \\
\hline 1550 & 3.24 & 9.85 & 0.00 & 0.04 & 1.98 & 5.13 \\
\hline 1560 & 3.21 & 11.57 & 0.00 & 0.07 & 2.26 & 5.24 \\
\hline 1570 & 3.50 & 13.46 & 0.03 & 0.06 & 3.11 & 4.84 \\
\hline 1580 & 3.55 & 14.05 & 0.03 & 0.08 & 4.86 & 6.55 \\
\hline 1590 & 4.16 & 17.25 & 0.03 & 0.09 & 4.37 & 6.06 \\
\hline 1600 & 4.40 & 19.62 & 0.08 & 0.16 & 9.05 & 6.52 \\
\hline 1610 & 4.73 & 22.54 & 0.06 & 0.27 & 10.22 & 5.99 \\
\hline 1620 & 5.02 & 24.86 & 0.11 & 0.30 & 10.35 & 6.34 \\
\hline 1630 & 5.21 & 27.77 & 0.12 & 0.38 & 11.37 & 5.90 \\
\hline 1640 & 5.42 & 31.16 & 0.17 & 0.38 & 12.22 & 5.68 \\
\hline 1650 & 5.61 & 35.25 & 0.22 & 0.47 & 12.49 & 5.63 \\
\hline 1660 & 5.58 & 36.79 & 0.21 & 0.49 & 13.29 & 5.40 \\
\hline 1670 & 5.46 & 34.86 & 0.25 & 0.90 & 11.80 & 5.50 \\
\hline 1680 & 5.40 & 34.97 & 0.40 & 0.90 & 12.41 & 5.28 \\
\hline 1690 & 5.39 & 35.05 & 0.55 & 1.53 & 12.02 & 4.90 \\
\hline 1700 & 5.51 & 36.47 & 0.57 & 2.32 & 11.98 & 4.67 \\
\hline 1710 & 5.69 & 38.85 & 0.79 & 2.88 & 13.18 & 4.96 \\
\hline 1720 & 5.82 & 40.10 & 0.90 & 3.39 & 14.13 & 4.38 \\
\hline 1730 & 5.73 & 41.64 & 0.78 & 3.51 & 13.62 & 4.14 \\
\hline 1740 & 6.05 & 44.19 & 1.01 & 3.42 & 12.83 & 4.24 \\
\hline 1750 & 6.26 & 46.86 & 1.09 & 4.16 & 16.10 & 4.26 \\
\hline 1760 & 6.66 & 52.58 & 1.39 & 5.60 & 16.68 & 4.04 \\
\hline 1770 & 7.01 & 59.05 & 1.74 & 6.16 & 19.32 & 4.15 \\
\hline 1780 & 7.59 & 67.16 & 2.31 & 7.85 & 19.33 & 3.95 \\
\hline 1790 & 8.28 & 85.18 & 4.03 & 10.84 & 24.16 & 4.10 \\
\hline 1800 & 9.09 & 123.06 & 6.29 & 21.84 & 33.85 & 4.38 \\
\hline 1810 & 10.31 & 169.96 & 7.52 & 28.75 & 43.32 & 4.63 \\
\hline 1820 & 11.98 & 183.16 & 7.06 & 29.16 & 38.19 & 4.48 \\
\hline 1830 & 13.77 & 215.53 & 6.55 & 25.88 & 36.56 & 4.85 \\
\hline 1840 & 15.64 & 254.62 & 6.59 & 26.18 & 39.17 & 4.28 \\
\hline 1850 & 17.59 & 303.99 & 7.05 & 28.39 & 39.47 & 4.10 \\
\hline 1860 & 19.72 & 394.58 & 8.90 & 30.28 & 43.18 & 4.27 \\
\hline
\end{tabular}


Table 8: Farm and other Property Incomes

\begin{tabular}{|c|c|c|c|c|c|c|}
\hline Decade & $\begin{array}{c}\text { Farm } \\
\text { Capital } \\
\text { Income } \\
(f, \mathrm{~m})\end{array}$ & $\begin{array}{l}\text { All Farm } \\
\text { Income } \\
(f, \mathrm{~m})\end{array}$ & $\begin{array}{l}\text { House } \\
\text { Rents } \\
(f, \mathrm{~m})\end{array}$ & $\begin{array}{c}\text { Mines etc } \\
\text { estimated } \\
\text { Capital } \\
\text { Income }\end{array}$ & $\begin{array}{l}\text { "Other" } \\
\text { Capital } \\
\text { Income } \\
(£, \mathrm{~m} .)\end{array}$ & $\begin{array}{c}\text { Net } \\
\text { Property } \\
\text { Incomes } \\
(£ \text { m. })\end{array}$ \\
\hline 1200 & 0.89 & 3.98 & 0.09 & - & 0.52 & 3.10 \\
\hline 1210 & 0.96 & 4.04 & 0.10 & - & 0.62 & 3.27 \\
\hline 1220 & 0.95 & 4.19 & 0.13 & - & 0.65 & 3.38 \\
\hline 1230 & 0.93 & 3.84 & 0.14 & - & 0.72 & 3.13 \\
\hline 1240 & 1.01 & 4.55 & 0.15 & - & 0.70 & 3.75 \\
\hline 1250 & 1.02 & 4.19 & 0.15 & - & 0.83 & 3.43 \\
\hline 1260 & 1.09 & 4.48 & 0.44 & - & 1.05 & 4.00 \\
\hline 1270 & 1.06 & 4.44 & 0.48 & - & 1.00 & 3.78 \\
\hline 1280 & 1.05 & 4.58 & 0.35 & - & 0.92 & 3.59 \\
\hline 1290 & 1.14 & 4.96 & 0.32 & - & 0.98 & 3.85 \\
\hline 1300 & 0.99 & 4.89 & 0.28 & - & 0.88 & 3.60 \\
\hline 1310 & 1.07 & 5.45 & 0.35 & - & 0.98 & 4.01 \\
\hline 1320 & 1.56 & 6.00 & 0.30 & - & 1.23 & 4.90 \\
\hline 1330 & 1.22 & 5.52 & 0.25 & - & 0.93 & 4.27 \\
\hline 1340 & 0.88 & 4.88 & 0.23 & - & 0.62 & 3.49 \\
\hline 1350 & 1.16 & 6.12 & 0.09 & - & 0.69 & 3.48 \\
\hline 1360 & 1.21 & 6.15 & 0.08 & - & 0.74 & 3.83 \\
\hline 1370 & 0.89 & 5.96 & 0.07 & - & 0.55 & 3.14 \\
\hline 1380 & 0.84 & 5.62 & 0.06 & - & 0.49 & 3.11 \\
\hline 1390 & 0.79 & 5.27 & 0.06 & - & 0.48 & 2.86 \\
\hline 1400 & 0.85 & 5.69 & 0.08 & - & 0.48 & 3.12 \\
\hline 1410 & 0.82 & 5.44 & 0.08 & - & 0.47 & 2.96 \\
\hline 1420 & 0.78 & 5.23 & 0.08 & - & 0.47 & 2.80 \\
\hline 1430 & 0.84 & 5.60 & 0.07 & - & 0.49 & 2.98 \\
\hline 1440 & 0.77 & 5.13 & 0.04 & - & 0.46 & 2.77 \\
\hline 1450 & 0.79 & 5.27 & 0.04 & - & 0.46 & 2.80 \\
\hline 1460 & 0.77 & 5.12 & 0.05 & - & 0.46 & 2.80 \\
\hline 1470 & 0.73 & 4.83 & 0.06 & - & 0.47 & 2.43 \\
\hline 1480 & 0.75 & 5.02 & 0.06 & - & 0.47 & 2.63 \\
\hline 1490 & 0.72 & 4.77 & 0.06 & - & 0.45 & 2.43 \\
\hline 1500 & 0.76 & 5.05 & 0.07 & - & 0.49 & 2.64 \\
\hline 1510 & 0.80 & 5.33 & 0.09 & - & 0.56 & 2.72 \\
\hline 1520 & 0.89 & 5.95 & 0.10 & - & 0.60 & 3.19 \\
\hline 1530 & 0.98 & 6.51 & 0.11 & - & 0.64 & 3.81 \\
\hline 1540 & 1.08 & 7.19 & 0.12 & - & 0.68 & 3.93 \\
\hline
\end{tabular}


Table 8 (cont.): Farm and other Property Incomes

\begin{tabular}{|c|c|c|c|c|c|c|}
\hline Decade & $\begin{array}{c}\text { Farm } \\
\text { Capital } \\
\text { Income } \\
(£, \mathrm{~m})\end{array}$ & $\begin{array}{c}\text { All Farm } \\
\text { Income } \\
(£, \mathrm{~m})\end{array}$ & $\begin{array}{l}\text { House } \\
\text { Rents } \\
(f, \mathrm{~m})\end{array}$ & $\begin{array}{c}\text { Mines etc } \\
\text { estimated } \\
\text { Capital } \\
\text { Income }\end{array}$ & $\begin{array}{l}\text { "Other" } \\
\text { Capital } \\
\text { Income } \\
(f \mathrm{~m} .)\end{array}$ & $\begin{array}{c}\text { Net } \\
\text { Property } \\
\text { Incomes } \\
(£, \mathrm{~m} .)\end{array}$ \\
\hline 1550 & 1.35 & 8.96 & 0.15 & - & 0.97 & 4.45 \\
\hline 1560 & 1.65 & 10.71 & 0.17 & - & 1.15 & 5.24 \\
\hline 1570 & 2.11 & 13.24 & 0.29 & - & 1.38 & 6.93 \\
\hline 1580 & 2.55 & 15.58 & 0.41 & - & 1.56 & 9.41 \\
\hline 1590 & 2.85 & 17.45 & 0.47 & - & 1.86 & 9.59 \\
\hline 1600 & 4.08 & 24.57 & 0.87 & - & 2.32 & 16.40 \\
\hline 1610 & 4.56 & 27.79 & 1.36 & - & 2.75 & 18.94 \\
\hline 1620 & 5.05 & 29.82 & 1.45 & - & 3.14 & 20.10 \\
\hline 1630 & 5.34 & 32.80 & 1.61 & - & 3.36 & 21.81 \\
\hline 1640 & 5.71 & 35.51 & 1.50 & - & 3.74 & 23.33 \\
\hline 1650 & 6.09 & 38.25 & 1.63 & - & 4.24 & 24.65 \\
\hline 1660 & 6.25 & 39.98 & 1.99 & - & 4.41 & 26.15 \\
\hline 1670 & 5.69 & 36.13 & 1.94 & - & 4.51 & 24.19 \\
\hline 1680 & 5.64 & 36.43 & 2.21 & - & 4.60 & 25.27 \\
\hline 1690 & 5.19 & 34.63 & 1.72 & - & 4.73 & 24.21 \\
\hline 1700 & 5.02 & 34.63 & 2.37 & - & 5.10 & 25.04 \\
\hline 1710 & 5.49 & 36.76 & 2.21 & - & 5.84 & 27.50 \\
\hline 1720 & 5.21 & 37.00 & 2.85 & - & 6.05 & 29.14 \\
\hline 1730 & 5.14 & 36.96 & 2.75 & 0.86 & 5.47 & 28.63 \\
\hline 1740 & 5.16 & 36.28 & 2.73 & 0.83 & 6.06 & 28.63 \\
\hline 1750 & 5.66 & 40.54 & 3.78 & 0.98 & 6.67 & 34.28 \\
\hline 1760 & 6.12 & 43.53 & 4.17 & 1.27 & 7.80 & 37.43 \\
\hline 1770 & 6.66 & 48.85 & 4.41 & 1.44 & 8.51 & 42.08 \\
\hline 1780 & 7.17 & 52.53 & 4.05 & 1.70 & 9.72 & 44.28 \\
\hline 1790 & 9.11 & 66.41 & 6.80 & 2.16 & 13.01 & 59.27 \\
\hline 1800 & 13.47 & 92.83 & 10.28 & 4.07 & 21.99 & 89.95 \\
\hline 1810 & 17.34 & 119.41 & 15.27 & 5.75 & 30.93 & 120.13 \\
\hline 1820 & 15.63 & 110.69 & 18.53 & 5.28 & 33.05 & 117.73 \\
\hline 1830 & 16.71 & 113.01 & 23.03 & 6.09 & 40.69 & 129.63 \\
\hline 1840 & 16.68 & 121.02 & 23.60 & 9.99 & 44.10 & 140.13 \\
\hline 1850 & 16.94 & 124.03 & 28.95 & 16.39 & 54.11 & 162.92 \\
\hline 1860 & 17.79 & 127.87 & 40.17 & 26.21 & 75.50 & 211.75 \\
\hline
\end{tabular}


Table 9: Property Income from Mining and Quarrying, 1730s-1860s

\begin{tabular}{|c|c|c|c|c|c|}
\hline Decade & $\begin{array}{l}\text { Coal Output } \\
\text { (m. tons) }\end{array}$ & $\begin{array}{l}\text { Coal Output } \\
\text { Value }(£, \mathrm{~m} .)\end{array}$ & $\begin{array}{l}\text { Coal Rents } \\
\quad(f, \mathrm{~m} .)\end{array}$ & $\begin{array}{c}\text { Capital } \\
\text { returns } \\
(f, \mathrm{~m} .)\end{array}$ & $\begin{array}{l}\text { All property } \\
\text { income } \\
(f, \mathrm{~m} .)^{*}\end{array}$ \\
\hline 1730 & 3.42 & 0.42 & 0.039 & 0.084 & 0.14 \\
\hline 1740 & 3.83 & 0.45 & 0.062 & 0.090 & 0.17 \\
\hline 1750 & 4.30 & 0.56 & 0.071 & 0.112 & 0.21 \\
\hline 1760 & 5.50 & 0.85 & 0.122 & 0.169 & 0.33 \\
\hline 1770 & 7.05 & 1.11 & 0.124 & 0.222 & 0.39 \\
\hline 1780 & 8.20 & 1.26 & 0.136 & 0.253 & 0.44 \\
\hline 1790 & 9.54 & 1.60 & 0.170 & 0.319 & 0.55 \\
\hline 1800 & 11.10 & 2.70 & 0.267 & 0.540 & 0.90 \\
\hline 1810 & 16.67 & 4.51 & 0.355 & 0.901 & 1.41 \\
\hline 1820 & 19.50 & 5.17 & 0.451 & 1.035 & 1.66 \\
\hline 1830 & 22.82 & 5.44 & 0.503 & 1.088 & 1.78 \\
\hline 1840 & 32.58 & 6.98 & 0.711 & 1.395 & 2.36 \\
\hline 1850 & 46.62 & 12.33 & 0.985 & 2.466 & 3.87 \\
\hline 1860 & 62.82 & 17.59 & 1.299 & 3.518 & 5.39 \\
\hline
\end{tabular}

Notes: $*$ including an addition of $12 \%$ for quarries. 
Table 10: Property Income from Railways, Canals, Iron Works, 1750s-1860s

\begin{tabular}{ccccccc}
\hline Decade & $\begin{array}{c}\text { Railway } \\
\text { miles }\end{array}$ & $\begin{array}{c}\text { Property } \\
\text { Income } \\
\text { Railways } \\
(£, \text { m. })\end{array}$ & $\begin{array}{c}\text { Canal } \\
\text { Miles }\end{array}$ & $\begin{array}{c}\text { Property } \\
\text { Income } \\
\text { Canals } \\
(£, \text { m. })\end{array}$ & $\begin{array}{c}\text { Iron Output } \\
\text { (m. tons) }\end{array}$ & $\begin{array}{c}\text { Property } \\
\text { Income Iron } \\
(£, \text { m. })\end{array}$ \\
\hline & & & & & \\
1730 & 0 & 0.00 & $(947)$ & 0.15 & 20 & 0.018 \\
1740 & 0 & 0.00 & $(947)$ & 0.14 & 20 & 0.018 \\
1750 & 0 & 0.00 & 947 & 0.15 & 20 & 0.018 \\
1760 & 0 & 0.00 & 1,028 & 0.17 & 20 & 0.018 \\
1770 & 0 & 0.00 & 1,486 & 0.26 & 20 & 0.018 \\
1780 & 0 & 0.00 & 1,788 & 0.34 & 49 & 0.023 \\
1790 & 0 & 0.00 & 2,149 & 0.47 & 75 & 0.061 \\
1800 & 0 & 0.00 & 2,849 & 0.79 & 150 & 0.135 \\
1810 & 0 & 0.00 & 3,091 & 1.03 & 200 & 0.208 \\
1820 & 50 & 0.06 & 3,258 & 0.95 & 249 & 0.180 \\
1830 & 338 & 0.42 & 3,412 & 0.98 & 480 & 0.270 \\
1840 & 2,530 & 3.33 & 3,495 & 1.06 & 641 & 0.342 \\
1850 & - & 8.27 & - & 0.80 & & 0.621 \\
1860 & - & 14.66 & - & 0.74 & & 0.961 \\
& & & & & & \\
\hline
\end{tabular}

Note: (..) indicates tentative estimate. 
Table 11: Implied Property Income from Roads, 1720s-1860s

\begin{tabular}{cccc}
\hline Decade & $\begin{array}{c}\text { Turnpike } \\
\text { Miles }\end{array}$ & $\begin{array}{c}\text { Total } \\
\text { Construction } \\
\text { Costs } \\
(£, \mathrm{~m} .)\end{array}$ & $\begin{array}{c}\text { Implied } \\
\text { Turnpike } \\
\text { Property } \\
\text { Income } \\
(£, \mathrm{~m} .)\end{array}$ \\
& & & \\
\hline & & & \\
1700 & 0 & 0.00 & 0.00 \\
1710 & 495 & 0.09 & 0.00 \\
1720 & 1,215 & 0.21 & 0.01 \\
1730 & 2,119 & 0.39 & 0.02 \\
1740 & 2,844 & 0.52 & 0.03 \\
1750 & 6,281 & 1.18 & 0.06 \\
1760 & 11,260 & 2.25 & 0.11 \\
1770 & 12,216 & 2.60 & 0.13 \\
1780 & 13,172 & 2.99 & 0.15 \\
1790 & 13,795 & 3.66 & 0.18 \\
1800 & 16,020 & 5.38 & 0.27 \\
1810 & 16,910 & 6.76 & 0.34 \\
1820 & 17,355 & 6.11 & 0.31 \\
1830 & 17,835 & 6.19 & 0.31 \\
1840 & 17,835 & 6.51 & 0.33 \\
1850 & 17,835 & 6.82 & 0.34 \\
1860 & 17,835 & 7.29 & 0.36 \\
& & & \\
\hline & & &
\end{tabular}


Table 12: Property Income from shipping

\begin{tabular}{|c|c|c|c|c|c|}
\hline Decade & $\begin{array}{l}\text { Ship Stock } \\
\text { (m. tons) }\end{array}$ & $\begin{array}{l}\text { Assumed } \\
\text { cost per } \\
\text { ton } \\
\left(\AA_{)}\right)\end{array}$ & $\begin{array}{l}\text { Ship } \\
\text { Stock } \\
(f, \mathrm{~m} .)\end{array}$ & $\begin{array}{c}\text { Feinstein } \\
\text { (1988) implied } \\
\text { ship stock } \\
(£, \mathrm{~m} .)\end{array}$ & $\begin{array}{l}\text { Ship rental } \\
\text { income } \\
(£, \mathrm{~m} .)\end{array}$ \\
\hline 1700 & 0.572 & 11.0 & 4.19 & - & 0.61 \\
\hline 1710 & 0.747 & 11.0 & 5.48 & - & 0.82 \\
\hline 1720 & 0.784 & 11.0 & 5.75 & - & 0.83 \\
\hline 1730 & 0.897 & 10.1 & 6.04 & - & 0.86 \\
\hline 1740 & 0.785 & 10.0 & 5.23 & - & 0.76 \\
\hline 1750 & 0.920 & 10.0 & 6.14 & - & 0.88 \\
\hline 1760 & 1.111 & 9.7 & 7.18 & 2.5 & 1.03 \\
\hline 1770 & 1.134 & 10.0 & 7.56 & 2.9 & 1.07 \\
\hline 1780 & 1.279 & 10.4 & 8.82 & 3.8 & 1.24 \\
\hline 1790 & 1.260 & 12.6 & 10.62 & 6.7 & 1.50 \\
\hline 1800 & 1.775 & 18.2 & 21.65 & 13.9 & 3.18 \\
\hline 1810 & 2.070 & 21.8 & 30.10 & 15.1 & 4.41 \\
\hline 1820 & 1.908 & 18.3 & 23.28 & 11.3 & 3.35 \\
\hline 1830 & 1.930 & 17.8 & 22.84 & 14.7 & 3.39 \\
\hline 1840 & 2.593 & 17.6 & 30.39 & 17.6 & 4.31 \\
\hline 1850 & 3.466 & 16.5 & 37.97 & 27.7 & 5.35 \\
\hline 1860 & 4.483 & 17.6 & 52.80 & 38.0 & 7.53 \\
\hline
\end{tabular}


Table 13: National Income and Factor Shares

\begin{tabular}{|c|c|c|c|c|c|c|}
\hline Decade & $\begin{array}{c}\text { Net } \\
\text { National } \\
\text { Income } \\
(£, \mathrm{~m} .)\end{array}$ & $\begin{array}{l}\text { Wage } \\
\text { Share in } \\
\text { National } \\
\text { Income }\end{array}$ & $\begin{array}{l}\text { Land } \\
\text { Share in } \\
\text { National } \\
\text { Income }\end{array}$ & $\begin{array}{l}\text { Capital } \\
\text { Share in } \\
\text { National } \\
\text { Income }\end{array}$ & $\begin{array}{c}\text { Farm } \\
\text { share in } \\
\text { Income }\end{array}$ & $\begin{array}{l}\text { Output } \\
\text { per } \\
\text { worker } \\
\text { (Ag vs } \\
\text { Non-Ag) }\end{array}$ \\
\hline 1200 & 5.94 & 0.478 & 0.270 & 0.252 & 0.65 & 1.26 \\
\hline 1210 & 5.52 & 0.472 & 0.260 & 0.268 & 0.62 & 1.11 \\
\hline 1220 & 6.65 & 0.492 & 0.245 & 0.263 & 0.60 & 1.01 \\
\hline 1230 & 5.32 & 0.509 & 0.208 & 0.282 & 0.57 & 0.88 \\
\hline 1240 & 7.23 & 0.481 & 0.262 & 0.257 & 0.60 & 1.01 \\
\hline 1250 & 7.05 & 0.513 & 0.203 & 0.284 & 0.56 & 0.86 \\
\hline 1260 & 8.12 & 0.506 & 0.175 & 0.319 & 0.54 & 0.79 \\
\hline 1270 & 7.97 & 0.526 & 0.155 & 0.319 & 0.53 & 0.75 \\
\hline 1280 & 7.97 & 0.549 & 0.160 & 0.290 & 0.53 & 0.75 \\
\hline 1290 & 8.57 & 0.551 & 0.164 & 0.285 & 0.53 & 0.76 \\
\hline 1300 & 8.53 & 0.578 & 0.170 & 0.252 & 0.53 & 0.75 \\
\hline 1310 & 9.63 & 0.583 & 0.168 & 0.249 & 0.53 & 0.76 \\
\hline 1320 & 10.00 & 0.510 & 0.181 & 0.309 & 0.58 & 0.94 \\
\hline 1330 & 9.07 & 0.529 & 0.206 & 0.265 & 0.59 & 0.97 \\
\hline 1340 & 7.73 & 0.549 & 0.227 & 0.224 & 0.61 & 1.05 \\
\hline 1350 & 9.16 & 0.620 & 0.169 & 0.211 & 0.66 & 1.30 \\
\hline 1360 & 9.28 & 0.587 & 0.194 & 0.219 & 0.66 & 1.27 \\
\hline 1370 & 9.03 & 0.652 & 0.180 & 0.168 & 0.66 & 1.27 \\
\hline 1380 & 8.32 & 0.626 & 0.206 & 0.167 & 0.67 & 1.38 \\
\hline 1390 & 7.93 & 0.639 & 0.193 & 0.168 & 0.66 & 1.29 \\
\hline 1400 & 8.35 & 0.626 & 0.204 & 0.169 & 0.68 & 1.41 \\
\hline 1410 & 8.06 & 0.632 & 0.197 & 0.170 & 0.67 & 1.37 \\
\hline 1420 & 7.84 & 0.642 & 0.188 & 0.170 & 0.67 & 1.33 \\
\hline 1430 & 8.30 & 0.641 & 0.191 & 0.168 & 0.67 & 1.38 \\
\hline 1440 & 7.66 & 0.638 & 0.196 & 0.166 & 0.67 & 1.36 \\
\hline 1450 & 7.80 & 0.640 & 0.194 & 0.166 & 0.68 & 1.40 \\
\hline 1460 & 7.64 & 0.634 & 0.200 & 0.167 & 0.67 & 1.36 \\
\hline 1470 & 7.42 & 0.672 & 0.159 & 0.168 & 0.65 & 1.24 \\
\hline 1480 & 7.60 & 0.653 & 0.179 & 0.168 & 0.66 & 1.31 \\
\hline 1490 & 7.27 & 0.664 & 0.168 & 0.169 & 0.65 & 1.28 \\
\hline 1500 & 7.76 & 0.660 & 0.170 & 0.170 & 0.65 & 1.25 \\
\hline 1510 & 8.41 & 0.677 & 0.151 & 0.172 & 0.63 & 1.14 \\
\hline 1520 & 9.26 & 0.655 & 0.173 & 0.172 & 0.64 & 1.19 \\
\hline 1530 & 10.04 & 0.619 & 0.209 & 0.172 & 0.65 & 1.23 \\
\hline 1540 & 10.95 & 0.641 & 0.188 & 0.171 & 0.65 & 1.27 \\
\hline
\end{tabular}


Table 13 (cont.): National Income and Factor Shares

\begin{tabular}{|c|c|c|c|c|c|c|}
\hline Decade & $\begin{array}{c}\text { National } \\
\text { Income } \\
(£, \mathrm{~m} .)\end{array}$ & $\begin{array}{l}\text { Wage } \\
\text { share in } \\
\text { National } \\
\text { Income }\end{array}$ & $\begin{array}{l}\text { Land } \\
\text { Share in } \\
\text { National } \\
\text { Income }\end{array}$ & $\begin{array}{l}\text { Capital } \\
\text { Share in } \\
\text { National } \\
\text { Income }\end{array}$ & $\begin{array}{c}\text { Farm } \\
\text { share in } \\
\text { Income }\end{array}$ & $\begin{array}{c}\text { Output } \\
\text { per worker } \\
\text { (Ag vs } \\
\text { Non-Ag) }\end{array}$ \\
\hline 1550 & 14.33 & 0.689 & 0.139 & 0.172 & 0.65 & 1.26 \\
\hline 1560 & 16.87 & 0.688 & 0.135 & 0.177 & 0.62 & 1.11 \\
\hline 1570 & 20.45 & 0.660 & 0.154 & 0.186 & 0.60 & 1.01 \\
\hline 1580 & 23.54 & 0.599 & 0.208 & 0.193 & 0.57 & 0.88 \\
\hline 1590 & 26.93 & 0.642 & 0.164 & 0.194 & 0.60 & 1.01 \\
\hline 1600 & 36.18 & 0.545 & 0.253 & 0.202 & 0.56 & 0.86 \\
\hline 1610 & 41.75 & 0.543 & 0.248 & 0.209 & 0.54 & 0.79 \\
\hline 1620 & 45.26 & 0.553 & 0.232 & 0.215 & 0.53 & 0.75 \\
\hline 1630 & 49.96 & 0.560 & 0.231 & 0.209 & 0.53 & 0.75 \\
\hline 1640 & 54.87 & 0.572 & 0.227 & 0.202 & 0.53 & 0.76 \\
\hline 1650 & 60.38 & 0.588 & 0.211 & 0.201 & 0.53 & 0.75 \\
\hline 1660 & 63.44 & 0.584 & 0.214 & 0.202 & 0.53 & 0.76 \\
\hline 1670 & 59.96 & 0.590 & 0.203 & 0.207 & 0.58 & 0.94 \\
\hline 1680 & 61.15 & 0.580 & 0.211 & 0.209 & 0.59 & 0.97 \\
\hline 1690 & 60.79 & 0.591 & 0.210 & 0.199 & 0.61 & 1.05 \\
\hline 1700 & 63.83 & 0.593 & 0.201 & 0.206 & 0.66 & 1.30 \\
\hline 1710 & 69.23 & 0.585 & 0.207 & 0.208 & 0.66 & 1.27 \\
\hline 1720 & 72.63 & 0.579 & 0.213 & 0.208 & 0.66 & 1.27 \\
\hline 1730 & 73.78 & 0.593 & 0.201 & 0.206 & 0.67 & 1.38 \\
\hline 1740 & 76.25 & 0.607 & 0.185 & 0.208 & 0.66 & 1.29 \\
\hline 1750 & 85.30 & 0.578 & 0.207 & 0.216 & 0.68 & 1.41 \\
\hline 1760 & 95.62 & 0.584 & 0.195 & 0.221 & 0.67 & 1.37 \\
\hline 1770 & 107.29 & 0.584 & 0.202 & 0.215 & 0.67 & 1.33 \\
\hline 1780 & 119.29 & 0.603 & 0.186 & 0.211 & 0.67 & 1.38 \\
\hline 1790 & 155.29 & 0.590 & 0.184 & 0.226 & 0.67 & 1.36 \\
\hline 1800 & 234.85 & 0.577 & 0.177 & 0.246 & 0.68 & 1.40 \\
\hline 1810 & 318.83 & 0.586 & 0.165 & 0.250 & 0.67 & 1.36 \\
\hline 1820 & 330.05 & 0.609 & 0.140 & 0.251 & 0.65 & 1.24 \\
\hline 1830 & 371.03 & 0.624 & 0.116 & 0.260 & 0.66 & 1.31 \\
\hline 1840 & 420.94 & 0.645 & 0.108 & 0.247 & 0.65 & 1.28 \\
\hline 1850 & 495.30 & 0.651 & 0.092 & 0.257 & 0.65 & 1.25 \\
\hline 1860 & 636.61 & 0.651 & 0.077 & 0.272 & 0.63 & 1.14 \\
\hline
\end{tabular}


Table 14: The Weights in the Expenditure Price Index

\begin{tabular}{lccccccc}
\hline Commodities & $1820-$ & $1741-$ & $1691-$ & $1375-$ & $1280-$ & $1247-$ & $1209-$ \\
& 69 & 1819 & 1740 & 1690 & 1375 & 79 & 46 \\
& & & & & & & \\
\hline & & & & & & & \\
Food & 0.450 & 0.540 & 0.600 & 0.650 & 0.635 & 0.680 & 0.750 \\
Fuel & 0.050 & 0.050 & 0.050 & 0.050 & 0.050 & 0.050 & - \\
Lodging & 0.100 & 0.050 & 0.050 & 0.050 & 0.080 & - & - \\
Light & 0.040 & 0.040 & 0.040 & 0.045 & 0.040 & 0.050 & - \\
Soap & 0.005 & 0.005 & 0.005 & 0.005 & 0.005 & - & - \\
Clothing & 0.110 & 0.120 & 0.120 & 0.120 & 0.120 & 0.150 & 0.200 \\
Services & 0.095 & 0.080 & 0.070 & 0.060 & 0.050 & 0.050 & 0.050 \\
Tobacco & 0.010 & 0.010 & - & - & - & - & - \\
Books & 0.020 & 0.015 & 0.010 & - & - & - & - \\
Manufactures & 0.040 & 0.030 & 0.020 & 0.020 & 0.020 & 0.020 & - \\
Investment & 0.080 & 0.060 & 0.035 & - & - & - & - \\
& & & & & & & \\
\hline
\end{tabular}

Table 15: The Weights in the National Food Price Index

\begin{tabular}{lcccc}
\hline Commodities & $1820-1869$ & $1650-1819$ & $1275-1649$ & $1209-1274$ \\
& & & & \\
\hline & & & & \\
Starches & 0.45 & 0.52 & 0.55 & 0.55 \\
Meat & 0.14 & 0.12 & 0.12 & 0.13 \\
Dairy & 0.14 & 0.12 & 0.12 & 0.13 \\
Fats & 0.03 & 0.03 & 0.03 & 0.03 \\
Fish & 0.03 & 0.03 & 0.03 & 0.03 \\
Drinks & 0.12 & 0.12 & 0.12 & 0.12 \\
Sugars & 0.07 & 0.04 & 0.01 & - \\
Salt & 0.01 & 0.01 & 0.01 & 0.01 \\
Spices & 0.01 & 0.01 & 0.01 & - \\
& & & & \\
\hline
\end{tabular}


Table 16: The Weights within the Starches Index

\begin{tabular}{lcccccc}
\hline Commodities & $1820-69$ & $1790-1819$ & $1760-1789$ & $1720-1759$ & $1660-1719$ & $1209-1659$ \\
& & & & & & \\
\hline & & & & & & \\
Wheat Bread & 0.667 & 0.750 & 0.800 & 0.840 & 0.850 & 0.850 \\
Barley & 0.020 & 0.020 & 0.030 & 0.030 & 0.040 & 0.050 \\
Oats/Oatmeal & 0.030 & 0.050 & 0.050 & 0.050 & 0.050 & 0.050 \\
Peas & 0.030 & 0.050 & 0.050 & 0.050 & 0.050 & 0.050 \\
Potatoes & 0.200 & 0.100 & 0.050 & 0.020 & - & - \\
Rice & 0.050 & 0.030 & 0.020 & 0.010 & 0.010 & - \\
& & & & & & \\
\hline
\end{tabular}

Table 17: The Weights in the Meat and Dairy Indices

\begin{tabular}{lcc}
\hline Commodities & $1620-1869$ & $1209-1619$ \\
& & \\
\hline Meat & & \\
Beef/Cattle & 0.400 & 0.400 \\
Mutton/Sheep & 0.300 & 0.300 \\
Pork/Pigs & 0.200 & 0.100 \\
Poultry & - & 0.100 \\
Eggs & 0.100 & 0.100 \\
& & \\
Dairy & & \\
Milk & 0.300 & 0.300 \\
Butter & 0.300 & 0.300 \\
Cheese & 0.400 & 0.400 \\
& & \\
\hline
\end{tabular}

Table 18: The Weights in the Drinks Price Index

\begin{tabular}{lcccccc}
\hline Commodities & $1820-$ & $1780-$ & $1760-$ & $1704-$ & $1486-$ & $1209-$ \\
& 1869 & 1819 & 1779 & 1759 & 1703 & 1485 \\
& & & & & & \\
\hline \\
Cider & - & - & - & - & - & 0.25 \\
Beer & 0.50 & 0.60 & 0.70 & 0.80 & 0.75 & 0.50 \\
Wine & 0.15 & 0.15 & 0.15 & 0.10 & 0.25 & 0.25 \\
Tea & 0.30 & 0.20 & 0.10 & 0.10 & - & - \\
Coffee & 0.05 & 0.05 & 0.05 & - & - & - \\
& & & & & & \\
\hline
\end{tabular}


Table 19: The Weights in the Fish Price Index

\begin{tabular}{lccccc}
\hline Commodities & $1831-$ & $1642-$ & $1584-$ & $1415-$ & $1209-$ \\
& 1869 & 1830 & 1641 & 1583 & 1414 \\
& & & & & \\
\hline & 1.00 & - & 0.50 & 0.50 & 1.00 \\
Herring & - & 1.00 & 0.50 & 0.25 & - \\
Salt Cod & - & - & - & 0.25 & - \\
Salt Salmon & & & & & \\
\hline
\end{tabular}

Table 20: The Weights in the Sugar Price Index

\begin{tabular}{lcccc}
\hline Commodities & $\begin{array}{c}1770- \\
1869\end{array}$ & $\begin{array}{c}1539- \\
1769\end{array}$ & $\begin{array}{c}1480- \\
1538\end{array}$ & $\begin{array}{c}1275- \\
1479\end{array}$ \\
& & & & \\
\hline & 0.65 & 0.50 & 0.333 & 0.10 \\
Sugar & 0.10 & - & - & - \\
Treacle & - & - & 0.333 & 0.60 \\
Honey & 0.25 & 0.50 & 0.333 & 0.30 \\
Currents/Raisins & & & & \\
\hline
\end{tabular}

Table 21: The cost of illumination through candles and coal gas

\begin{tabular}{lcc}
\hline Decade & $\begin{array}{c}1 \text { lb tallow candles } \\
(\text { d. })\end{array}$ & $\begin{array}{c}1 \\
\text { cubic feet gas } \\
(\text { d. })\end{array}$ \\
\hline $1815-19$ & & \\
$1820 \mathrm{~s}$ & 10.5 & 3.5 \\
$1830 \mathrm{~s}$ & 7.1 & 3.0 \\
$1840 \mathrm{~s}$ & 6.2 & 2.4 \\
$1850 \mathrm{~s}$ & 5.9 & 1.7 \\
$1860 \mathrm{~s}$ & 6.3 & 1.1 \\
& 6.4 & 1.0 \\
\hline
\end{tabular}


Table 22: The Weights in the Light Price Index

\begin{tabular}{cccccc}
\hline Commodity & DE & DE & DE & DE & DE \\
& $1850-1869$ & $1815-1849$ & $1281-1814$ & $1261-1280$ & $1209-1260$ \\
& & & & & \\
\hline Tallow Candles & 0.600 & 0.750 & 0.750 & - & - \\
Wax Candles & 0.050 & 0.075 & 0.150 & 0.250 & - \\
Lamp Oil & 0.100 & 0.075 & 0.100 & - & - \\
Coal-Gas & 0.250 & 0.100 & - & 0.750 & 1.000 \\
Tallow & - & - & - & & \\
\hline
\end{tabular}

Table 23: The Weights in the Fuel Price Index

\begin{tabular}{|l|l|l|l|l|l|}
\hline Commodity & $\begin{array}{l}\text { DE } \\
1820-1869\end{array}$ & $\begin{array}{l}\text { DE } \\
1750-1819\end{array}$ & $\begin{array}{l}\text { DE } \\
1690-1749\end{array}$ & $\begin{array}{l}\text { DE } \\
1590-1689\end{array}$ & $\begin{array}{l}\text { DE } \\
1209-1589\end{array}$ \\
\hline & & & & & \\
\hline Wood & 0.16 & 0.32 & 0.48 & 0.60 & 0.64 \\
\hline Charcoal & 0.04 & 0.08 & 0.12 & 0.15 & 0.16 \\
\hline Coal & 0.80 & 0.60 & 0.40 & 0.25 & 0.20 \\
\hline & & & & & \\
\hline
\end{tabular}

Table 24: The Weights in the Clothing Price Index

\begin{tabular}{lccccccc}
\hline Commodity & DE & DE & DE & DE & DE & DE & DE \\
& $1856-69$ & $1820-55$ & $1790-1819$ & $1765-89$ & $1633-1764$ & $1576-1632$ & $1549-1575$ \\
& & & & & & & \\
\hline & & & & & & & \\
Wool cloth & 0.200 & 0.190 & 0.190 & 0.190 & 0.190 & 0.285 & 0.500 \\
Linen cloth & 0.075 & 0.071 & 0.095 & 0.124 & 0.142 & 0.142 & 0.250 \\
Cotton cloth & 0.075 & 0.071 & 0.048 & 0.019 & - & - & - \\
Silk Thread & - & 0.050 & 0.050 & 0.050 & 0.050 & 0.050 & - \\
Stockings & 0.050 & 0.048 & 0.048 & 0.048 & 0.048 & - & - \\
Suit of clothes & 0.500 & 0.475 & 0.475 & 0.475 & 0.475 & 0.333 & - \\
Shoes & 0.100 & 0.095 & 0.095 & 0.095 & 0.095 & 0.095 & 0.100 \\
Leather gloves & - & - & - & - & - & - & - \\
Labor & - & - & - & - & - & 0.095 & 0.15 \\
& & & & & & & \\
\hline
\end{tabular}


Table 25: Exports and Imports, 1784-1856

\begin{tabular}{|c|c|c|c|c|c|c|c|c|}
\hline Item & 1784-6 & 1794-6 & 1804-6 & 1814-6 & 1824-6 & 1834-6 & 1844-6 & $1854-6$ \\
\hline Exports $\mathcal{A}$. & 11.4 & 20.2 & 34.6 & 40.3 & 33.5 & 43.9 & 55.5 & 97.3 \\
\hline Imports $\hat{f}, \mathrm{~m}$. & 16.1 & 24.8 & 38.4 & 45.4 & 47.7 & 50.4 & 59.8 & 109.7 \\
\hline Ratio to NNI & 0.125 & 0.158 & 0.164 & 0.146 & 0.133 & 0.144 & 0.148 & 0.219 \\
\hline \multicolumn{9}{|l|}{ Export Share } \\
\hline Cotton Goods & 0.059 & 0.158 & 0.396 & 0.396 & 0.436 & 0.441 & 0.403 & 0.310 \\
\hline Woolen Goods & 0.285 & 0.240 & 0.165 & 0.182 & 0.173 & 0.168 & 0.173 & 0.132 \\
\hline Ironwares & 0.090 & 0.093 & 0.066 & 0.018 & 0.021 & 0.023 & 0.038 & 0.061 \\
\hline Iron & 0.000 & 0.000 & 0.002 & 0.006 & 0.010 & 0.024 & 0.045 & 0.076 \\
\hline Manufactures & 0.278 & 0.258 & 0.177 & 0.160 & 0.177 & 0.157 & 0.155 & 0.185 \\
\hline Coal & 0.017 & 0.012 & 0.009 & 0.009 & 0.011 & 0.018 & 0.046 & 0.074 \\
\hline Refined Sugar & 0.026 & 0.050 & 0.040 & 0.061 & 0.019 & 0.018 & 0.007 & 0.004 \\
\hline \multicolumn{9}{|l|}{ Import Shares } \\
\hline Cotton & 0.093 & 0.089 & 0.121 & 0.142 & 0.117 & 0.221 & 0.147 & 0.151 \\
\hline Grains & 0.038 & 0.079 & 0.061 & 0.056 & 0.072 & 0.054 & 0.117 & 0.159 \\
\hline Sugar & 0.124 & 0.156 & 0.132 & 0.156 & 0.107 & 0.081 & 0.081 & 0.068 \\
\hline Timber & 0.048 & 0.055 & 0.070 & 0.070 & 0.070 & 0.049 & 0.074 & 0.064 \\
\hline Wool & 0.014 & 0.020 & 0.039 & 0.072 & 0.074 & 0.110 & 0.075 & 0.041 \\
\hline Oils & 0.016 & 0.015 & 0.020 & 0.026 & 0.019 & 0.021 & 0.021 & 0.029 \\
\hline Silk & 0.059 & 0.035 & 0.036 & 0.041 & 0.057 & 0.070 & 0.053 & 0.040 \\
\hline Tea & 0.114 & 0.080 & 0.073 & 0.068 & 0.062 & 0.046 & 0.030 & 0.031 \\
\hline Flax & 0.029 & 0.022 & 0.030 & 0.024 & 0.033 & 0.035 & 0.029 & 0.023 \\
\hline Wine & 0.045 & 0.047 & 0.036 & 0.031 & 0.049 & 0.028 & 0.015 & 0.017 \\
\hline Butter & 0.020 & 0.021 & 0.021 & 0.025 & 0.027 & 0.028 & 0.027 & 0.025 \\
\hline hemp, jute & 0.020 & 0.040 & 0.042 & 0.024 & 0.017 & 0.012 & 0.015 & 0.016 \\
\hline Copper & 0.000 & 0.001 & 0.001 & 0.000 & 0.001 & 0.001 & 0.005 & 0.015 \\
\hline Indigo & 0.019 & 0.042 & 0.033 & 0.043 & 0.053 & 0.023 & 0.030 & 0.015 \\
\hline Meat & 0.017 & 0.024 & 0.022 & 0.025 & 0.031 & 0.029 & 0.035 & 0.026 \\
\hline Rice & 0.008 & 0.009 & 0.004 & 0.004 & 0.003 & 0.003 & 0.008 & 0.010 \\
\hline Spirits & 0.019 & 0.032 & 0.017 & 0.007 & 0.007 & 0.010 & 0.007 & 0.008 \\
\hline Tobacco & 0.001 & 0.004 & 0.006 & 0.008 & 0.007 & 0.006 & 0.006 & 0.007 \\
\hline Cheese & 0.000 & 0.003 & 0.007 & 0.007 & 0.010 & 0.007 & 0.011 & 0.007 \\
\hline Coffee & 0.001 & -0.013 & 0.003 & -0.014 & 0.007 & 0.008 & 0.007 & 0.006 \\
\hline Tallow & 0.027 & 0.024 & 0.034 & 0.030 & 0.021 & 0.025 & 0.023 & 0.017 \\
\hline Linens & 0.082 & 0.058 & 0.049 & 0.037 & 0 & 0 & 0 & 0 \\
\hline
\end{tabular}


Table 26: Exports and Imports, 1699-1774

\begin{tabular}{|c|c|c|c|c|}
\hline Item & 1699-1701 & $1722-4$ & $1752-4$ & $1772-4$ \\
\hline Exports $£$ m. & 4.43 & 5.04 & 8.42 & 9.85 \\
\hline Imports $£$. & 3.86 & 4.04 & 4.71 & 6.92 \\
\hline Ratio to NNI & 0.072 & 0.066 & 0.086 & 0.088 \\
\hline \multicolumn{5}{|l|}{ Export Shares } \\
\hline Cotton Goods & 0.000 & 0.000 & 0.000 & 0.022 \\
\hline Woolen Goods & 0.687 & 0.592 & 0.467 & 0.425 \\
\hline Ironwares & 0.026 & 0.036 & 0.070 & 0.122 \\
\hline Manufactures & 0.063 & 0.074 & 0.134 & 0.187 \\
\hline Coal & 0.008 & 0.019 & 0.021 & 0.034 \\
\hline Grains & 0.033 & 0.117 & 0.107 & 0.004 \\
\hline \multicolumn{5}{|l|}{ Import Shares } \\
\hline Cotton & - & - & - & 0.020 \\
\hline Grains & 0.000 & 0.000 & 0.000 & 0.043 \\
\hline Sugar & 0.089 & 0.177 & 0.185 & 0.280 \\
\hline Timber & 0.036 & 0.039 & 0.050 & 0.046 \\
\hline Wool & 0.052 & 0.028 & 0.016 & 0.015 \\
\hline Silk & 0.073 & 0.162 & 0.133 & 0.091 \\
\hline Tea & 0.000 & 0.000 & 0.117 & 0.080 \\
\hline Wine & 0.139 & 0.142 & 0.087 & 0.059 \\
\hline Tallow & 0.022 & 0.004 & 0.001 & 0.019 \\
\hline Linens & 0.187 & 0.193 & 0.136 & 0.022 \\
\hline
\end{tabular}


Table 27: Price Indices, 1200s-1860s

\begin{tabular}{|c|c|c|c|c|c|c|}
\hline Decade & $\begin{array}{c}\text { Domestic } \\
\text { Expenditures }\end{array}$ & Imports & Exports & Imports/NDI & $\begin{array}{l}\text { National } \\
\text { Product }\end{array}$ & $\begin{array}{c}\text { Cost of } \\
\text { Living }\end{array}$ \\
\hline 1200 & 6.59 & - & - & - & 7.13 & 6.54 \\
\hline 1210 & 7.47 & - & - & - & 8.08 & 7.57 \\
\hline 1220 & 8.32 & - & - & - & 9.00 & 8.53 \\
\hline 1230 & 8.23 & - & - & - & 5.56 & 8.39 \\
\hline 1240 & 8.72 & - & - & - & 9.43 & 8.87 \\
\hline 1250 & 8.83 & - & - & - & 9.56 & 9.05 \\
\hline 1260 & 9.33 & - & - & - & 10.10 & 9.46 \\
\hline 1270 & 11.09 & - & - & - & 12.00 & 11.63 \\
\hline 1280 & 10.01 & - & - & - & 10.83 & 10.40 \\
\hline 1290 & 11.26 & - & - & - & 12.19 & 11.61 \\
\hline 1300 & 11.07 & - & - & - & 11.97 & 11.20 \\
\hline 1310 & 13.59 & - & - & - & 14.70 & 14.14 \\
\hline 1320 & 12.58 & - & - & - & 13.61 & 12.97 \\
\hline 1330 & 10.98 & - & - & - & 11.88 & 11.06 \\
\hline 1340 & 10.37 & - & - & - & 11.22 & 10.47 \\
\hline 1350 & 12.99 & - & - & - & 14.05 & 13.09 \\
\hline 1360 & 13.46 & - & - & - & 14.57 & 13.52 \\
\hline 1370 & 13.68 & - & - & - & 14.80 & 13.78 \\
\hline 1380 & 11.57 & - & - & - & 12.52 & 11.40 \\
\hline 1390 & 11.81 & - & - & - & 12.78 & 11.68 \\
\hline 1400 & 12.33 & - & - & - & 13.34 & 12.22 \\
\hline 1410 & 12.52 & - & - & - & 13.55 & 12.40 \\
\hline 1420 & 11.72 & - & - & - & 12.68 & 11.47 \\
\hline 1430 & 12.77 & - & - & - & 13.82 & 12.73 \\
\hline 1440 & 11.43 & - & - & - & 12.37 & 11.14 \\
\hline 1450 & 11.57 & - & - & - & 12.52 & 11.35 \\
\hline 1460 & 11.73 & - & - & - & 12.70 & 11.51 \\
\hline 1470 & 11.82 & - & - & - & 12.79 & 11.60 \\
\hline 1480 & 12.48 & - & - & - & 13.50 & 12.37 \\
\hline 1490 & 11.79 & - & - & - & 12.75 & 11.54 \\
\hline 1500 & 12.09 & - & - & - & 13.08 & 11.94 \\
\hline 1510 & 12.44 & - & - & - & 13.46 & 12.24 \\
\hline 1520 & 14.32 & - & - & - & 15.50 & 14.37 \\
\hline 1530 & 15.09 & - & - & - & 16.33 & 15.21 \\
\hline 1540 & 17.01 & - & - & - & 18.40 & 17.19 \\
\hline
\end{tabular}


Table 27: Price Indices, 1200s-1860s (cont.)

\begin{tabular}{|c|c|c|c|c|c|c|}
\hline Decade & $\begin{array}{c}\text { Domestic } \\
\text { Expenditures }\end{array}$ & Imports & Exports & Imports/NNI & $\begin{array}{l}\text { National } \\
\text { Product }\end{array}$ & $\begin{array}{c}\text { Cost of } \\
\text { Living }\end{array}$ \\
\hline 1550 & 25.3 & - & - & - & 27.4 & 26.1 \\
\hline 1560 & 27.1 & - & - & - & 29.3 & 27.5 \\
\hline 1570 & 29.8 & - & - & - & 32.2 & 30.4 \\
\hline 1580 & 33.1 & - & - & - & 35.9 & 34.1 \\
\hline 1590 & 41.4 & - & - & - & 44.8 & 43.8 \\
\hline 1600 & 43.0 & - & - & - & 46.5 & 45.1 \\
\hline 1610 & 48.7 & - & - & - & 52.7 & 51.4 \\
\hline 1620 & 49.0 & - & - & - & 53.0 & 51.7 \\
\hline 1630 & 57.0 & - & - & - & 61.7 & 60.7 \\
\hline 1640 & 59.1 & - & - & - & 63.9 & 62.7 \\
\hline 1650 & 59.3 & - & - & - & 64.2 & 62.2 \\
\hline 1660 & 59.7 & - & - & - & 64.6 & 63.0 \\
\hline 1670 & 59.0 & - & - & - & 63.8 & 62.0 \\
\hline 1680 & 56.6 & 85.0 & 151.7 & - & 61.3 & 58.9 \\
\hline 1690 & 63.0 & 102.5 & 163.3 & 0.066 & 68.0 & 66.4 \\
\hline 1700 & 58.4 & 112.0 & 168.8 & 0.066 & 62.8 & 59.8 \\
\hline 1710 & 62.8 & 104.8 & 168.6 & - & 67.8 & 65.6 \\
\hline 1720 & 62.6 & 101.4 & 168.4 & 0.060 & 67.8 & 64.9 \\
\hline 1730 & 57.8 & 96.7 & 158.0 & - & 62.5 & 58.8 \\
\hline 1740 & 59.3 & 99.3 & 158.1 & - & 64.0 & 60.6 \\
\hline 1750 & 62.3 & 94.7 & 157.4 & 0.078 & 67.5 & 65.1 \\
\hline 1760 & 65.9 & 91.1 & 156.8 & - & 71.6 & 69.1 \\
\hline 1770 & 71.6 & 95.6 & 157.7 & 0.079 & 77.4 & 76.4 \\
\hline 1780 & 74.3 & 98.1 & 162.5 & 0.112 & 80.5 & 78.3 \\
\hline 1790 & 85.2 & 110.0 & 174.4 & 0.141 & 91.6 & 89.8 \\
\hline 1800 & 114.6 & 137.3 & 167.3 & 0.145 & 118.6 & 122.5 \\
\hline 1810 & 130.2 & 146.8 & 179.5 & 0.129 & 135.0 & 137.1 \\
\hline 1820 & 108.5 & 104.3 & 125.8 & 0.118 & 112.1 & 110.2 \\
\hline 1830 & 100.9 & 97.2 & 108.6 & 0.127 & 103.0 & 101.3 \\
\hline 1840 & 96.9 & 80.0 & 83.0 & 0.130 & 97.8 & 98.8 \\
\hline 1850 & 93.3 & 82.8 & 81.8 & 0.193 & 93.2 & 95.1 \\
\hline 1860 & 100.0 & 100.0 & 100.0 & 0.250 & 100.0 & 100.0 \\
\hline
\end{tabular}


Table 28: Real National Income, 1200s-1860s

\begin{tabular}{|c|c|c|c|c|c|}
\hline Decade & $\begin{array}{l}\text { Real National } \\
\text { Income }\left(\mathrm{P}_{\mathrm{DE}}\right)\end{array}$ & $\begin{array}{c}\text { Real } \\
\text { National } \\
\text { Income } \\
\left(\mathrm{P}_{\mathrm{NDP}}\right)\end{array}$ & $\begin{array}{c}\text { Real } \\
\text { National } \\
\text { Income } / \mathrm{N} \\
\left(\mathrm{P}_{\mathrm{DE}}\right)\end{array}$ & $\begin{array}{c}\text { Real } \\
\text { National } \\
\text { Income } / \mathrm{N} \\
\left(\mathrm{P}_{\mathrm{NDP}}\right)\end{array}$ & Real Wage \\
\hline 1200 & 14.0 & 12.9 & 81.6 & 75.4 & 68.8 \\
\hline 1210 & 13.1 & 12.1 & 76.3 & 70.5 & 58.6 \\
\hline 1220 & 12.6 & 11.7 & 67.0 & 61.9 & 53.0 \\
\hline 1230 & 12.0 & 11.1 & 60.8 & 56.2 & 49.8 \\
\hline 1240 & 13.1 & 12.1 & 66.9 & 61.9 & 52.0 \\
\hline 1250 & 12.5 & 11.5 & 64.2 & 59.4 & 52.9 \\
\hline 1260 & 13.4 & 12.4 & 61.7 & 57.0 & 50.7 \\
\hline 1270 & 11.2 & 10.3 & 45.3 & 41.9 & 37.5 \\
\hline 1280 & 12.4 & 11.5 & 50.4 & 46.6 & 43.8 \\
\hline 1290 & 11.8 & 10.9 & 43.9 & 40.6 & 37.9 \\
\hline 1300 & 12.0 & 11.1 & 44.7 & 41.3 & 41.9 \\
\hline 1310 & 11.2 & 10.3 & 39.6 & 36.6 & 36.6 \\
\hline 1320 & 12.4 & 11.5 & 49.5 & 45.7 & 40.7 \\
\hline 1330 & 13.0 & 12.0 & 54.8 & 50.6 & 47.4 \\
\hline 1340 & 11.6 & 10.8 & 51.4 & 47.5 & 47.1 \\
\hline 1350 & 11.0 & 10.2 & 61.5 & 56.8 & 61.8 \\
\hline 1360 & 10.7 & 9.9 & 66.9 & 61.9 & 64.2 \\
\hline 1370 & 10.5 & 9.7 & 65.8 & 60.9 & 69.7 \\
\hline 1380 & 11.3 & 10.4 & 79.2 & 73.2 & 82.3 \\
\hline 1390 & 10.5 & 9.7 & 73.9 & 68.4 & 77.7 \\
\hline 1400 & 10.6 & 9.8 & 79.6 & 73.6 & 81.6 \\
\hline 1410 & 10.1 & 9.3 & 78.5 & 72.6 & 81.5 \\
\hline 1420 & 10.4 & 9.7 & 83.7 & 77.4 & 89.1 \\
\hline 1430 & 10.2 & 9.5 & 80.6 & 74.5 & 84.6 \\
\hline 1440 & 10.5 & 9.7 & 91.3 & 84.4 & 97.1 \\
\hline 1450 & 10.5 & 9.7 & 91.2 & 84.3 & 96.6 \\
\hline 1460 & 10.2 & 9.4 & 87.0 & 80.4 & 91.2 \\
\hline 1470 & 9.8 & 9.1 & 81.5 & 75.3 & 90.6 \\
\hline 1480 & 9.5 & 8.8 & 78.2 & 72.3 & 83.6 \\
\hline 1490 & 9.6 & 8.9 & 82.4 & 76.2 & 90.9 \\
\hline 1500 & 10.0 & 9.3 & 77.6 & 71.7 & 84.3 \\
\hline 1510 & 10.6 & 9.8 & 74.6 & 69.0 & 83.4 \\
\hline 1520 & 10.2 & 9.4 & 68.3 & 63.1 & 72.8 \\
\hline 1530 & 10.4 & 9.6 & 68.1 & 63.0 & 68.0 \\
\hline 1540 & 10.2 & 9.4 & 67.2 & 62.1 & 69.4 \\
\hline
\end{tabular}


Table 28: Real National Income, 1200s-1860s (cont.)

\begin{tabular}{|c|c|c|c|c|c|}
\hline Decade & $\begin{array}{l}\text { Real National } \\
\text { Income }\left(\mathrm{P}_{\mathrm{DE}}\right)\end{array}$ & $\begin{array}{c}\text { Real } \\
\text { National } \\
\text { Income } \\
\left(\mathrm{P}_{\mathrm{NDP}}\right)\end{array}$ & $\begin{array}{c}\text { Real } \\
\text { National } \\
\text { Income/N } \\
\left(\mathrm{P}_{\mathrm{DE}}\right)\end{array}$ & $\begin{array}{c}\text { Real } \\
\text { National } \\
\text { Income } / \mathrm{N} \\
\left(\mathrm{P}_{\mathrm{NDP}}\right)\end{array}$ & Real Wage \\
\hline 1550 & 8.9 & 8.3 & 54.4 & 50.3 & 59.1 \\
\hline 1560 & 9.8 & 9.0 & 60.0 & 55.4 & 65.4 \\
\hline 1570 & 10.8 & 10.0 & 60.7 & 56.1 & 63.7 \\
\hline 1580 & 11.1 & 10.3 & 61.8 & 57.1 & 58.1 \\
\hline 1590 & 10.3 & 9.5 & 57.3 & 52.9 & 48.0 \\
\hline 1600 & 13.2 & 12.2 & 59.3 & 54.8 & 49.5 \\
\hline 1610 & 13.4 & 12.4 & 55.9 & 51.7 & 46.2 \\
\hline 1620 & 14.4 & 13.3 & 56.8 & 52.5 & 47.8 \\
\hline 1630 & 13.7 & 12.6 & 51.8 & 47.9 & 43.8 \\
\hline 1640 & 14.6 & 13.5 & 53.3 & 49.2 & 46.3 \\
\hline 1650 & 16.0 & 14.8 & 56.3 & 52.1 & 51.1 \\
\hline 1660 & 16.6 & 15.4 & 58.9 & 54.4 & 52.5 \\
\hline 1670 & 15.9 & 14.7 & 57.4 & 53.1 & 51.6 \\
\hline 1680 & 16.9 & 15.6 & 61.7 & 56.9 & 55.0 \\
\hline 1690 & 15.2 & 14.0 & 55.5 & 51.5 & 49.4 \\
\hline 1700 & 17.1 & 15.9 & 61.2 & 56.9 & 55.7 \\
\hline 1710 & 17.2 & 15.9 & 59.7 & 55.3 & 52.3 \\
\hline 1720 & 18.1 & 16.7 & 61.3 & 56.7 & 53.2 \\
\hline 1730 & 20.1 & 18.6 & 69.3 & 64.1 & 61.9 \\
\hline 1740 & 20.3 & 18.8 & 66.2 & 61.3 & 60.7 \\
\hline 1750 & 21.6 & 19.9 & 68.0 & 62.8 & 57.6 \\
\hline 1760 & 22.8 & 21.0 & 67.8 & 62.4 & 57.4 \\
\hline 1770 & 23.6 & 21.8 & 66.4 & 61.4 & 55.2 \\
\hline 1780 & 25.3 & 23.3 & 65.7 & 60.7 & 56.6 \\
\hline 1790 & 28.7 & 26.7 & 68.4 & 63.6 & 57.5 \\
\hline 1800 & 32.2 & 31.2 & 69.9 & 67.6 & 55.5 \\
\hline 1810 & 38.6 & 37.2 & 73.9 & 71.3 & 60.3 \\
\hline 1820 & 47.9 & 46.4 & 78.9 & 76.4 & 69.4 \\
\hline 1830 & 57.8 & 56.7 & 83.0 & 81.3 & 77.4 \\
\hline 1840 & 68.5 & 67.8 & 86.4 & 85.6 & 82.9 \\
\hline 1850 & 83.5 & 83.6 & 93.7 & 93.7 & 91.1 \\
\hline 1860 & 100.0 & 100.0 & 100.0 & 100.0 & 100.0 \\
\hline
\end{tabular}


Table 29: The Weights in the Workers Cost of Living Price Index

\begin{tabular}{lccccccc}
\hline Commodities & $1840-69$ & $1820-39$ & $1730-1819$ & $1375-1729$ & $1280-1374$ & $1245-79$ & $1209-44$ \\
& & & & & & & \\
\hline & & & & & & & \\
Food & 0.620 & 0.670 & 0.720 & 0.720 & 0.720 & 0.750 & 0.800 \\
Fuel & 0.050 & 0.050 & 0.050 & 0.050 & 0.040 & 0.050 & - \\
Lodging & 0.100 & 0.075 & 0.045 & 0.045 & 0.075 & - & - \\
Light & 0.040 & 0.040 & 0.040 & 0.040 & 0.030 & 0.040 & - \\
Soap & 0.010 & 0.005 & 0.005 & 0.005 & 0.005 & - & - \\
Clothing & 0.120 & 0.120 & 0.120 & 0.120 & 0.120 & 0.150 & 0.180 \\
Services & 0.020 & 0.010 & 0.010 & 0.020 & 0.010 & 0.010 & 0.020 \\
Tobacco & 0.010 & 0.010 & - & - & - & - & - \\
Books & 0.015 & 0.010 & - & - & - & - & - \\
Manufactures & 0.015 & 0.010 & 0.010 & - & - & - & - \\
& & & & & & & \\
\hline
\end{tabular}

Table 30: The Weights in the Cost of Living Food Price Index

\begin{tabular}{lcccc}
\hline Commodities & $1840-69$ & $1820-39$ & $1730-1819$ & $1209-1729$ \\
& & & & \\
\hline & & & & \\
Starches & 0.50 & 0.55 & 0.60 & 0.60 \\
Meat & 0.12 & 0.11 & 0.10 & 0.11 \\
Dairy & 0.12 & 0.11 & 0.10 & 0.11 \\
Fats & 0.03 & 0.03 & 0.03 & 0.04 \\
Fish & 0.03 & 0.03 & 0.03 & 0.03 \\
Drinks & 0.11 & 0.10 & 0.09 & 0.10 \\
Sugars & 0.07 & 0.05 & 0.03 & - \\
Salt & 0.01 & 0.01 & 0.01 & 0.01 \\
Spices & 0.01 & 0.01 & 0.01 & - \\
& & & & \\
\hline
\end{tabular}


Table 31: The Weights in the Cost of Living Drinks Price Index

\begin{tabular}{|c|c|c|c|c|c|c|}
\hline Commodities & $\begin{array}{c}1820- \\
1869\end{array}$ & $\begin{array}{c}1780- \\
1819\end{array}$ & $\begin{array}{l}1760- \\
1779\end{array}$ & $\begin{array}{c}1704- \\
1759\end{array}$ & $\begin{array}{c}1486- \\
1703\end{array}$ & $\begin{array}{c}1209 \\
1485\end{array}$ \\
\hline Cider & - & - & - & - & - & 0.25 \\
\hline Beer & 0.65 & 0.75 & 0.85 & 0.85 & 0.75 & - \\
\hline Wine & 0.00 & 0.00 & 0.00 & 0.05 & 0.25 & 0.25 \\
\hline Tea & 0.30 & 0.20 & 0.10 & 0.10 & - & - \\
\hline Coffee & 0.05 & 0.05 & 0.05 & - & - & - \\
\hline Barley & - & - & - & - & - & 0.50 \\
\hline
\end{tabular}

Table 32: The Weights in the Domestic Expenditure and Cost of Living Indices, 1760-1869

\begin{tabular}{lccc}
\hline Commodity & Weight DE & Weigh COL & Price 1860s/Price 1760s \\
\hline & & & \\
Salt & 0.005 & $\mathbf{0 . 0 0 6}$ & 0.26 \\
Cotton cloth & 0.006 & $\mathbf{0 . 0 0 7}$ & 0.38 \\
Sugar & 0.027 & $\mathbf{0 . 0 3 0}$ & 0.84 \\
Linen cloth & 0.011 & $\mathbf{0 . 0 1 6}$ & 0.87 \\
Tallow Candles & 0.029 & $\mathbf{0 . 0 3 8}$ & 0.94 \\
Stockings & 0.005 & $\mathbf{0 . 0 0 6}$ & 1.03 \\
Coal & 0.035 & 0.035 & 1.06 \\
Wool cloth & 0.022 & $\mathbf{0 . 0 2 4}$ & 1.10 \\
Suit of clothes & 0.055 & $\mathbf{0 . 0 5 7}$ & 1.12 \\
Firewood & 0.015 & 0.015 & 1.26 \\
Manufactures & 0.011 & 1.30 \\
Starches & $\mathbf{0 . 0 3 0}$ & $\mathbf{0 . 3 8 7}$ & 1.53 \\
Wax Candles & 0.259 & 0.000 & 1.61 \\
Shoes & $\mathbf{0 . 0 0 5}$ & $\mathbf{0 . 0 1 1}$ & 1.66 \\
Investment & 0.011 & 0.000 & 1.68 \\
Lamp Oil & $\mathbf{0 . 0 7 4}$ & 0.000 & 1.81 \\
Beer & $\mathbf{0 . 0 0 4}$ & $\mathbf{0 . 0 4 8}$ & 1.89 \\
Meat & 0.036 & $\mathbf{0 . 0 7 3}$ & 2.91 \\
Dairy & 0.066 & $\mathbf{0 . 0 7 3}$ & 2.27 \\
Wine & 0.066 & 0.000 & 2.48 \\
Services & $\mathbf{0 . 0 0 9}$ & 0.013 & \\
Lodging & $\mathbf{0 . 0 8 7}$ & 0.054 & \\
& $\mathbf{0 . 0 6 8}$ & & \\
\hline
\end{tabular}


Table 33: Efficiency Indices, 1200s-1860s

\begin{tabular}{|c|c|c|c|}
\hline Decade & $\begin{array}{c}\text { Indirect Tax } \\
\text { Share }\end{array}$ & $\begin{array}{l}\text { Efficiency } \\
\qquad\left(\mathrm{P}_{\mathrm{DE}}\right)\end{array}$ & $\begin{array}{c}\text { Efficiency } \\
\left(\mathrm{P}_{\mathrm{NDP}}\right)\end{array}$ \\
\hline 1200 & 0.00 & 108.2 & 100.0 \\
\hline 1210 & 0.00 & 98.7 & 91.3 \\
\hline 1220 & 0.00 & 90.7 & 83.8 \\
\hline 1230 & 0.00 & 85.4 & 79.0 \\
\hline 1240 & 0.00 & 88.5 & 81.8 \\
\hline 1250 & 0.00 & 85.0 & 78.6 \\
\hline 1260 & 0.00 & 81.1 & 74.9 \\
\hline 1270 & 0.00 & 66.0 & 61.0 \\
\hline 1280 & 0.00 & 70.8 & 65.5 \\
\hline 1290 & 0.00 & 66.2 & 61.2 \\
\hline 1300 & 0.00 & 66.2 & 61.2 \\
\hline 1310 & 0.00 & 60.6 & 56.0 \\
\hline 1320 & 0.00 & 73.2 & 67.7 \\
\hline 1330 & 0.00 & 75.4 & 69.7 \\
\hline 1340 & 0.00 & 70.4 & 65.1 \\
\hline 1350 & 0.00 & 73.7 & 68.1 \\
\hline 1360 & 0.00 & 77.4 & 71.6 \\
\hline 1370 & 0.00 & 74.9 & 69.2 \\
\hline 1380 & 0.00 & 85.8 & 79.3 \\
\hline 1390 & 0.00 & 80.2 & 74.2 \\
\hline 1400 & 0.00 & 83.7 & 77.3 \\
\hline 1410 & 0.00 & 82.1 & 75.9 \\
\hline 1420 & 0.00 & 85.8 & 79.3 \\
\hline 1430 & 0.00 & 83.9 & 77.5 \\
\hline 1440 & 0.00 & 91.1 & 84.2 \\
\hline 1450 & 0.00 & 91.0 & 84.1 \\
\hline 1460 & 0.00 & 87.5 & 80.9 \\
\hline 1470 & 0.00 & 82.1 & 75.9 \\
\hline 1480 & 0.00 & 79.1 & 73.1 \\
\hline 1490 & 0.00 & 80.6 & 74.5 \\
\hline 1500 & 0.00 & 77.7 & 71.8 \\
\hline 1510 & 0.00 & 75.8 & 70.1 \\
\hline 1520 & 0.00 & 71.0 & 65.6 \\
\hline 1530 & 0.00 & 70.5 & 65.1 \\
\hline 1540 & 0.00 & 68.6 & 63.4 \\
\hline
\end{tabular}


Table 32: Efficiency Indices, 1200s-1860s (cont.)

\begin{tabular}{|c|c|c|c|}
\hline Decade & $\begin{array}{c}\text { Indirect Tax } \\
\text { Share }\end{array}$ & $\begin{array}{c}\text { Efficiency } \\
\left(\mathrm{P}_{\mathrm{DE}}\right)\end{array}$ & $\begin{array}{c}\text { Efficiency } \\
\left(\mathrm{P}_{\mathrm{NDP}}\right)\end{array}$ \\
\hline 1550 & 0.003 & 53.3 & 49.2 \\
\hline 1560 & 0.004 & 57.4 & 53.0 \\
\hline 1570 & 0.003 & 58.5 & 54.0 \\
\hline 1580 & 0.003 & 58.3 & 53.9 \\
\hline 1590 & 0.003 & 48.6 & 44.9 \\
\hline 1600 & 0.004 & 56.6 & 52.2 \\
\hline 1610 & 0.006 & 54.3 & 50.2 \\
\hline 1620 & 0.007 & 55.7 & 51.5 \\
\hline 1630 & 0.008 & 52.3 & 48.3 \\
\hline 1640 & 0.007 & 54.0 & 49.9 \\
\hline 1650 & 0.008 & 56.9 & 52.6 \\
\hline 1660 & 0.008 & 58.2 & 53.8 \\
\hline 1670 & 0.015 & 56.1 & 51.8 \\
\hline 1680 & 0.015 & 58.9 & 54.4 \\
\hline 1690 & 0.025 & 54.0 & 50.1 \\
\hline 1700 & 0.037 & 58.7 & 54.6 \\
\hline 1710 & 0.042 & 57.8 & 53.5 \\
\hline 1720 & 0.048 & 59.2 & 54.7 \\
\hline 1730 & 0.049 & 65.1 & 60.3 \\
\hline 1740 & 0.046 & 63.0 & 58.5 \\
\hline 1750 & 0.051 & 64.4 & 59.5 \\
\hline 1760 & 0.061 & 64.6 & 59.5 \\
\hline 1770 & 0.059 & 64.4 & 59.6 \\
\hline 1780 & 0.067 & 65.0 & 60.0 \\
\hline 1790 & 0.072 & 67.7 & 62.9 \\
\hline 1800 & 0.095 & 69.6 & 67.4 \\
\hline 1810 & 0.094 & 74.6 & 72.1 \\
\hline 1820 & 0.092 & 79.9 & 77.5 \\
\hline 1830 & 0.072 & 84.7 & 83.0 \\
\hline 1840 & 0.063 & 89.0 & 88.1 \\
\hline 1850 & 0.058 & 95.1 & 95.2 \\
\hline 1860 & 0.048 & 100.0 & 100.0 \\
\hline
\end{tabular}


Table 34: Real Income and Factor Shares, 1860-2008

\begin{tabular}{|c|c|c|c|c|c|c|c|c|}
\hline Decade & $\begin{array}{l}\text { Real } \\
\text { Income } \\
\text { per } \\
\text { person } \\
\text { (Index) }\end{array}$ & $\begin{array}{l}\text { Share } \\
\text { Land } \\
\text { Rents }\end{array}$ & $\begin{array}{l}\text { Share } \\
\text { Labor }\end{array}$ & $\begin{array}{l}\text { Share } \\
\text { Urban } \\
\text { Rents }\end{array}$ & $\begin{array}{l}\text { Share } \\
\text { Capital }\end{array}$ & $\begin{array}{l}\text { Real } \\
\text { wage }\end{array}$ & $\begin{array}{l}\text { Skill } \\
\text { Premium }\end{array}$ & $\begin{array}{l}\text { Efficiency } \\
\text { (Index) }\end{array}$ \\
\hline $1860-9$ & 100 & 0.075 & 0.656 & 0.026 & 0.243 & 100 & 1.53 & 100 \\
\hline $1870-9$ & 110 & 0.060 & 0.664 & 0.026 & 0.250 & 128 & 1.42 & 119 \\
\hline 1880-9 & 118 & 0.052 & 0.675 & 0.041 & 0.233 & 148 & 1.46 & 130 \\
\hline 1890-9 & 129 & 0.034 & 0.682 & 0.045 & 0.239 & 172 & 1.42 & 140 \\
\hline 1900-9 & 141 & 0.025 & 0.671 & 0.033 & 0.271 & 182 & 1.41 & 146 \\
\hline 1910-9 & 147 & 0.022 & 0.722 & 0.022 & 0.239 & 162 & 1.36 & 138 \\
\hline 1920-9 & 141 & 0.007 & 0.759 & 0.021 & 0.209 & 208 & 1.22 & 157 \\
\hline 1930-9 & 168 & 0.006 & 0.750 & 0.029 & 0.212 & 236 & 1.25 & 169 \\
\hline 1940-9 & 211 & 0.004 & 0.782 & 0.048 & 0.165 & 230 & 1.20 & 169 \\
\hline 1950-9 & 233 & 0.004 & 0.802 & 0.039 & 0.154 & 255 & 1.10 & 181 \\
\hline 1960-9 & 292 & 0.004 & 0.802 & 0.043 & 0.151 & 303 & 1.09 & 204 \\
\hline 1970-9 & 364 & 0.004 & 0.805 & 0.044 & 0.146 & 507 & 1.16 & 300 \\
\hline 1980-9 & 439 & 0.004 & 0.772 & 0.049 & 0.174 & 552 & 1.17 & 329 \\
\hline 1990-9 & 548 & 0.002 & 0.745 & 0.045 & 0.207 & 731 & 1.18 & 367 \\
\hline $2000-8$ & 694 & 0.002 & 0.750 & 0.042 & 0.206 & 887 & 1.22 & 407 \\
\hline
\end{tabular}


Appendix Table A1: Individual Price Indices, Decadal, 1209-1869

\begin{tabular}{|c|c|c|c|c|c|c|c|}
\hline Decade & $\begin{array}{c}\text { Bread } \\
(\mathrm{d} . / \mathrm{lb})\end{array}$ & $\begin{array}{c}\text { Barley } \\
\text { (s./bu) }\end{array}$ & $\begin{array}{l}\text { Oatmeal } \\
\text { (d./1b) }\end{array}$ & $\begin{array}{l}\text { Peas } \\
\text { (s./bu) }\end{array}$ & $\begin{array}{l}\text { Potatoes } \\
\text { (s./cwt) }\end{array}$ & $\begin{array}{l}\text { Rice } \\
\text { (d./lb) }\end{array}$ & $\begin{array}{l}\text { Starches } \\
(1860 \mathrm{~s}=100)\end{array}$ \\
\hline 1200 & 0.091 & 0.206 & 0.076 & 0.222 & - & - & 4.35 \\
\hline 1210 & 0.122 & 0.247 & 0.093 & 0.325 & - & - & 5.87 \\
\hline 1220 & 0.139 & 0.309 & 0.114 & 0.428 & - & - & 6.50 \\
\hline 1230 & 0.130 & 0.277 & 0.133 & 0.385 & - & - & 6.33 \\
\hline 1240 & 0.137 & 0.300 & 0.132 & 0.423 & - & - & 6.68 \\
\hline 1250 & 0.148 & 0.353 & 0.148 & 0.491 & - & - & 7.41 \\
\hline 1260 & 0.145 & 0.330 & 0.153 & 0.411 & - & - & 7.10 \\
\hline 1270 & 0.208 & 0.466 & 0.186 & 0.635 & - & - & 10.11 \\
\hline 1280 & 0.177 & 0.383 & 0.178 & 0.488 & - & - & 8.62 \\
\hline 1290 & 0.224 & 0.502 & 0.188 & 0.675 & - & - & 10.84 \\
\hline 1300 & 0.182 & 0.400 & 0.169 & 0.502 & - & - & 8.81 \\
\hline 1310 & 0.273 & 0.606 & 0.229 & 0.793 & - & - & 13.18 \\
\hline 1320 & 0.231 & 0.488 & 0.222 & 0.621 & - & - & 11.19 \\
\hline 1330 & 0.181 & 0.384 & 0.181 & 0.563 & - & - & 8.86 \\
\hline 1340 & 0.176 & 0.388 & 0.160 & 0.477 & - & - & 8.51 \\
\hline 1350 & 0.240 & 0.587 & 0.235 & 0.647 & - & - & 11.68 \\
\hline 1360 & 0.241 & 0.685 & 0.209 & 0.646 & - & - & 11.75 \\
\hline 1370 & 0.259 & 0.580 & 0.203 & 0.645 & - & - & 12.37 \\
\hline 1380 & 0.183 & 0.376 & 0.216 & 0.477 & - & - & 8.92 \\
\hline 1390 & 0.193 & 0.434 & 0.226 & 0.540 & - & - & 9.49 \\
\hline 1400 & 0.210 & 0.437 & 0.215 & 0.508 & - & - & 10.14 \\
\hline 1410 & 0.216 & 0.439 & 0.202 & 0.556 & - & - & 10.39 \\
\hline 1420 & 0.181 & 0.370 & 0.192 & 0.452 & - & - & 8.77 \\
\hline 1430 & 0.236 & 0.407 & 0.192 & 0.644 & - & - & 11.21 \\
\hline 1440 & 0.182 & 0.313 & 0.165 & 0.446 & - & - & 8.64 \\
\hline 1450 & 0.201 & 0.318 & 0.155 & 0.372 & - & - & 9.29 \\
\hline 1460 & 0.201 & 0.362 & 0.161 & 0.446 & - & - & 9.43 \\
\hline 1470 & 0.210 & 0.319 & 0.162 & 0.452 & - & - & 9.78 \\
\hline 1480 & 0.235 & 0.409 & 0.160 & 0.597 & - & - & 11.04 \\
\hline 1490 & 0.205 & 0.318 & 0.156 & 0.417 & - & - & 9.50 \\
\hline 1500 & 0.229 & 0.348 & 0.172 & 0.448 & - & - & 10.57 \\
\hline 1510 & 0.222 & 0.404 & 0.179 & 0.504 & - & - & 10.45 \\
\hline 1520 & 0.295 & 0.488 & 0.251 & 0.794 & - & - & 13.99 \\
\hline 1530 & 0.323 & 0.468 & 0.279 & 0.644 & - & - & 15.02 \\
\hline 1540 & 0.355 & 0.569 & 0.284 & 0.748 & - & - & 16.54 \\
\hline
\end{tabular}


Table A1 (cont.): Individual Price Indices, 1209-1869

\begin{tabular}{|c|c|c|c|c|c|c|c|}
\hline Decade & $\begin{array}{l}\text { Bread } \\
\text { (d./lb) }\end{array}$ & $\begin{array}{l}\text { Barley } \\
\text { (s./bu) }\end{array}$ & $\begin{array}{l}\text { Oatmeal } \\
\text { (d./lb) }\end{array}$ & $\begin{array}{l}\text { Peas } \\
\text { (s./bu) }\end{array}$ & $\begin{array}{l}\text { Potatoes } \\
\text { (s./cwt) }\end{array}$ & $\begin{array}{l}\text { Rice } \\
\text { (d./lb) }\end{array}$ & $\begin{array}{l}\text { Starches } \\
\text { (Index) }\end{array}$ \\
\hline 1550 & 0.575 & 1.082 & 0.523 & 1.596 & - & - & 27.5 \\
\hline 1560 & 0.526 & 0.997 & 0.561 & 1.458 & - & - & 25.4 \\
\hline 1570 & 0.593 & 1.021 & 0.544 & 1.427 & - & - & 28.2 \\
\hline 1580 & 0.693 & 1.137 & 0.609 & 1.781 & - & - & 32.9 \\
\hline 1590 & 1.036 & 1.752 & 0.890 & 2.442 & - & - & 48.9 \\
\hline 1600 & 1.006 & 1.635 & 0.760 & 2.260 & - & - & 47.0 \\
\hline 1610 & 1.188 & 1.967 & 0.863 & 2.696 & - & - & 55.4 \\
\hline 1620 & 1.177 & 1.886 & 0.812 & 2.441 & - & - & 54.8 \\
\hline 1630 & 1.424 & 2.627 & 1.240 & 3.462 & - & - & 67.7 \\
\hline 1640 & 1.448 & 2.410 & 1.033 & 2.842 & - & - & 67.1 \\
\hline 1650 & 1.374 & 2.235 & 1.030 & 3.423 & - & - & 64.4 \\
\hline 1660 & 1.365 & 2.259 & 1.069 & 2.727 & - & 2.111 & 63.6 \\
\hline 1670 & 1.301 & 2.091 & 1.026 & 2.801 & - & 2.427 & 60.9 \\
\hline 1680 & 1.128 & 1.992 & 1.013 & 2.794 & - & 2.832 & 53.9 \\
\hline 1690 & 1.461 & 2.113 & 1.055 & 2.903 & - & \begin{tabular}{|l|}
3.046 \\
\end{tabular} & 67.7 \\
\hline 1700 & 1.119 & 1.968 & 0.947 & 2.639 & - & 2.920 & 53.2 \\
\hline 1710 & 1.343 & 2.268 & 1.050 & 3.021 & - & 2.597 & 63.1 \\
\hline 1720 & 1.288 & 2.416 & 1.047 & 2.940 & 6.847 & 2.406 & 61.0 \\
\hline 1730 & 1.067 & 2.035 & 0.896 & 2.410 & 5.804 & 2.456 & 50.7 \\
\hline 1740 & 1.100 & 1.964 & 1.048 & 2.396 & 4.108 & 2.639 & 51.9 \\
\hline 1750 & 1.281 & 2.195 & 1.082 & 2.661 & 8.616 & 2.322 & 60.5 \\
\hline 1760 & 1.405 & 2.470 & 1.226 & 2.876 & 4.573 & 1.875 & 65.4 \\
\hline 1770 & 1.661 & 2.824 & 1.390 & 3.636 & 3.186 & 1.643 & 75.0 \\
\hline 1780 & 1.693 & 2.846 & 1.412 & 3.589 & 3.607 & 2.618 & 77.3 \\
\hline 1790 & 2.062 & 3.760 & 1.674 & 4.538 & 3.690 & 2.118 & 92.8 \\
\hline 1800 & 3.010 & 5.436 & 2.719 & 6.866 & 4.944 & 2.935 & 134.7 \\
\hline 1810 & 3.341 & 5.650 & 2.782 & 6.578 & 5.301 & 3.495 & 147.9 \\
\hline 1820 & 2.226 & 3.962 & 2.280 & 4.652 & 4.828 & 3.185 & 104.1 \\
\hline 1830 & 2.080 & 3.931 & 2.198 & 4.521 & 5.158 & 2.462 & 99.3 \\
\hline 1840 & 2.057 & 3.973 & 2.106 & 4.534 & 6.322 & 2.457 & 102.3 \\
\hline 1850 & 1.976 & 4.125 & 1.863 & 4.453 & 6.964 & 1.721 & 99.5 \\
\hline 1860 & 1.951 & 4.490 & 2.179 & 4.472 & 7.498 & 1.379 & 100.0 \\
\hline
\end{tabular}


Table A1 (cont.): Individual Price Indices, 1209-1869

\begin{tabular}{|c|c|c|c|c|c|c|c|}
\hline Decade & $\begin{array}{c}\text { Beef } \\
\text { (d./lb) }\end{array}$ & $\begin{array}{l}\text { Cattle } \\
\text { (s. ) }\end{array}$ & $\begin{array}{l}\text { Mutton } \\
\text { (d./lb) }\end{array}$ & $\begin{array}{l}\text { Pork } \\
\text { (d./lb) }\end{array}$ & $\begin{array}{c}\text { Eggs } \\
\text { (d./doz) }\end{array}$ & $\begin{array}{l}\text { Hens } \\
\text { (d.) }\end{array}$ & $\begin{array}{l}\text { Meat } \\
(1860 \mathrm{~s}=100)\end{array}$ \\
\hline & & & & & & & \\
\hline 1200 & 0.170 & 5.40 & 0.175 & - & 0.260 & 1.84 & 2.58 \\
\hline 1210 & 0.190 & 6.03 & 0.179 & - & 0.260 & 2.62 & 2.79 \\
\hline 1220 & 0.225 & 7.17 & 0.239 & - & 0.320 & 1.83 & 3.32 \\
\hline 1230 & 0.238 & 7.56 & 0.272 & - & 0.493 & 2.31 & 3.79 \\
\hline 1240 & 0.277 & 8.80 & 0.248 & - & 0.402 & 2.38 & 3.85 \\
\hline 1250 & 0.251 & 7.99 & 0.218 & - & 0.404 & 2.31 & 3.50 \\
\hline 1260 & 0.291 & 9.26 & 0.242 & - & 0.424 & 2.58 & 3.91 \\
\hline 1270 & 0.336 & 10.70 & 0.301 & - & 0.506 & 2.60 & 4.63 \\
\hline 1280 & 0.305 & 9.69 & 0.291 & - & 0.489 & 2.74 & 4.41 \\
\hline 1290 & 0.298 & 9.48 & 0.286 & - & 0.469 & 3.01 & 4.35 \\
\hline 1300 & 0.336 & 10.70 & 0.286 & - & 0.523 & 3.16 & 4.63 \\
\hline 1310 & 0.449 & 14.27 & 0.361 & - & 0.628 & 3.57 & 5.89 \\
\hline 1320 & 0.462 & 14.69 & 0.411 & - & 0.604 & 3.81 & 6.28 \\
\hline 1330 & 0.397 & 12.61 & 0.290 & - & 0.554 & 3.54 & 5.08 \\
\hline 1340 & 0.336 & 10.70 & 0.259 & - & 0.563 & 3.21 & 4.51 \\
\hline 1350 & 0.362 & 11.50 & 0.300 & - & 0.584 & 3.65 & 5.01 \\
\hline 1360 & 0.455 & 14.47 & 0.382 & - & 0.580 & 4.10 & 6.12 \\
\hline 1370 & 0.503 & 15.99 & 0.445 & - & 0.735 & 4.81 & 7.05 \\
\hline 1380 & 0.419 & 13.32 & 0.367 & - & 0.700 & 4.73 & 6.03 \\
\hline 1390 & 0.428 & 13.62 & 0.335 & - & 0.684 & 4.78 & 5.86 \\
\hline 1400 & 0.442 & 14.07 & 0.398 & - & 0.671 & 4.54 & 6.30 \\
\hline 1410 & 0.410 & 13.03 & 0.370 & - & 0.656 & 4.71 & 5.95 \\
\hline 1420 & 0.407 & 12.94 & 0.318 & - & 0.649 & 4.56 & 5.56 \\
\hline 1430 & 0.403 & 12.81 & 0.385 & - & 0.699 & 4.64 & 6.03 \\
\hline 1440 & 0.375 & 11.93 & 0.356 & - & 0.682 & 4.65 & 5.67 \\
\hline 1450 & 0.379 & 12.05 & 0.318 & - & 0.703 & 4.86 & 5.48 \\
\hline 1460 & 0.426 & 13.56 & 0.421 & - & 0.668 & 4.81 & 6.38 \\
\hline 1470 & 0.428 & 13.61 & 0.395 & - & 0.700 & 4.83 & 6.24 \\
\hline 1480 & 0.406 & 12.86 & 0.414 & - & 0.707 & 4.63 & 6.23 \\
\hline 1490 & 0.341 & 10.84 & 0.375 & - & 0.832 & 5.23 & 5.71 \\
\hline 1500 & 0.440 & 13.38 & 0.395 & - & 1.000 & 5.77 & 6.65 \\
\hline 1510 & 0.521 & 16.22 & 0.446 & - & 0.865 & 5.26 & 7.32 \\
\hline 1520 & 0.549 & 17.68 & 0.539 & - & 1.121 & 6.36 & 8.41 \\
\hline 1530 & 0.615 & 19.13 & 0.596 & - & 1.198 & 7.32 & 9.24 \\
\hline 1540 & 0.663 & 21.82 & 0.717 & - & 2.200 & 7.99 & 11.14 \\
\hline
\end{tabular}


Table A1 (cont.): Individual Price Indices, 1209-1869

\begin{tabular}{|c|c|c|c|c|c|c|c|}
\hline Decade & $\begin{array}{c}\text { Beef } \\
\text { (d./1b) }\end{array}$ & $\begin{array}{c}\text { Cattle } \\
\text { (s. ) }\end{array}$ & $\begin{array}{l}\text { Mutton } \\
\text { (d./1b) }\end{array}$ & $\begin{array}{l}\text { Pork } \\
\text { (d./1b) }\end{array}$ & $\begin{array}{c}\text { Eggs } \\
\text { (d./doz) }\end{array}$ & $\begin{array}{l}\text { Hens } \\
\text { (d.) }\end{array}$ & $\begin{array}{l}\text { Meat } \\
(1860 \mathrm{~s}= \\
100)\end{array}$ \\
\hline 1550 & 1.189 & 41.60 & 1.017 & - & 3.35 & 10.63 & 17.4 \\
\hline 1560 & 1.247 & 45.22 & 1.315 & - & 3.67 & 11.98 & 20.1 \\
\hline 1570 & 1.359 & 63.56 & 1.475 & - & 3.70 & 13.37 & 22.1 \\
\hline 1580 & 1.595 & 66.12 & 1.821 & - & 3.21 & 12.17 & 25.0 \\
\hline 1590 & 2.023 & 84.81 & 2.356 & - & 3.87 & 12.99 & 31.2 \\
\hline 1600 & 2.110 & 83.57 & 2.594 & - & 3.93 & 12.08 & 33.1 \\
\hline 1610 & 2.539 & - & 2.744 & - & 4.20 & - & 37.7 \\
\hline 1620 & 2.498 & - & 2.855 & - & 3.90 & - & 37.7 \\
\hline 1630 & 2.692 & - & 2.905 & 3.198 & 4.76 & - & 40.3 \\
\hline 1640 & 2.893 & - & 3.236 & 3.390 & 4.13 & - & 43.3 \\
\hline 1650 & 2.907 & - & 3.588 & 2.776 & 4.62 & - & 43.9 \\
\hline 1660 & 3.000 & - & 3.545 & 3.707 & 4.85 & - & 47.2 \\
\hline 1670 & 2.911 & - & 3.341 & 3.241 & 5.03 & - & 44.8 \\
\hline 1680 & 2.953 & - & 3.435 & 3.170 & 5.60 & - & 45.7 \\
\hline 1690 & 3.003 & - & 3.481 & 3.713 & 6.05 & - & 48.0 \\
\hline 1700 & 2.927 & - & 3.199 & 3.532 & 6.11 & - & 45.9 \\
\hline 1710 & 3.082 & - & 3.269 & 3.668 & 6.39 & - & 47.8 \\
\hline 1720 & 3.063 & - & 3.192 & 3.567 & 6.36 & - & 47.0 \\
\hline 1730 & 2.910 & - & 3.042 & 3.194 & 6.42 & - & 44.5 \\
\hline 1740 & 3.194 & - & 3.281 & 3.466 & 6.25 & - & 47.9 \\
\hline 1750 & 3.198 & - & 3.303 & 3.617 & 6.55 & - & 48.6 \\
\hline 1760 & 3.474 & - & 3.501 & 4.031 & 6.68 & - & 52.4 \\
\hline 1770 & 4.019 & - & 4.000 & 4.555 & 7.60 & - & 60.0 \\
\hline 1780 & 4.157 & - & 4.066 & 4.462 & 8.39 & - & 61.5 \\
\hline 1790 & 5.240 & - & 5.118 & 5.380 & 8.60 & - & 75.1 \\
\hline 1800 & 7.882 & - & 7.518 & 6.959 & 11.60 & - & 107.7 \\
\hline 1810 & 8.306 & - & 7.943 & 7.804 & 14.99 & - & 117.3 \\
\hline 1820 & 7.065 & - & 6.869 & 6.266 & 11.68 & - & 98.3 \\
\hline 1830 & 6.290 & - & 6.408 & 4.722 & 11.26 & - & 86.5 \\
\hline 1840 & 6.001 & - & 6.245 & 6.119 & 8.61 & - & 86.1 \\
\hline 1850 & 6.019 & - & 6.058 & 6.310 & 8.43 & - & 86.1 \\
\hline 1860 & 6.815 & - & 7.062 & 7.420 & 10.65 & - & 100.0 \\
\hline
\end{tabular}


Table A1 (cont.): Individual Price Indices, 1209-1869

\begin{tabular}{|c|c|c|c|c|c|c|c|}
\hline Decade & $\begin{array}{l}\text { Cheese } \\
\text { (d./1b) }\end{array}$ & $\begin{array}{l}\text { Butter } \\
\text { (d./lb) }\end{array}$ & $\begin{array}{c}\text { Milk } \\
\text { (d./ga ) }\end{array}$ & $\begin{array}{l}\text { Dairy } \\
(1860 \mathrm{~s} \\
=100)\end{array}$ & $\begin{array}{c}\text { Fats } \\
(1860 \mathrm{~s}= \\
100)\end{array}$ & $\begin{array}{l}\text { Herring } \\
\text { (s./100) }\end{array}$ & $\begin{array}{l}\text { Salt Cod } \\
\text { (s/fish) }\end{array}$ \\
\hline 1200 & 0.388 & - & - & 6.08 & 8.2 & 0.280 & - \\
\hline 1210 & 0.400 & - & - & 6.27 & 7.4 & 0.499 & - \\
\hline 1220 & 0.420 & - & - & 6.56 & 15.5 & - & - \\
\hline 1230 & 0.499 & - & - & 7.82 & 12.7 & - & - \\
\hline 1240 & 0.481 & - & - & 7.54 & 10.9 & 0.522 & - \\
\hline 1250 & 0.469 & - & - & 7.40 & 11.1 & 0.503 & - \\
\hline 1260 & 0.524 & 0.877 & - & 8.16 & 11.2 & 0.519 & - \\
\hline 1270 & 0.552 & 0.874 & - & 8.44 & 11.9 & 0.457 & - \\
\hline 1280 & 0.508 & 0.824 & 1.01 & 7.84 & 11.2 & 0.651 & - \\
\hline 1290 & 0.552 & 0.863 & & 8.40 & 10.5 & 0.650 & - \\
\hline 1300 & 0.572 & 0.891 & 1.32 & 8.82 & 12.7 & 0.726 & - \\
\hline 1310 & 0.688 & 1.234 & 1.43 & 10.85 & 16.4 & 0.855 & - \\
\hline 1320 & 0.650 & 1.200 & 1.54 & 10.82 & 15.1 & 0.884 & - \\
\hline 1330 & 0.583 & 1.008 & 1.54 & 9.82 & 13.0 & 0.832 & - \\
\hline 1340 & 0.505 & 1.071 & 1.38 & 9.23 & 12.1 & 0.899 & - \\
\hline 1350 & 0.625 & 1.075 & 1.21 & 9.45 & 13.6 & 1.339 & - \\
\hline 1360 & 0.597 & 1.261 & 1.24 & 10.12 & 14.1 & 1.180 & - \\
\hline 1370 & 0.520 & 1.285 & 1.23 & 9.77 & 15.4 & 1.163 & 1.00 \\
\hline 1380 & 0.519 & 1.122 & & 9.10 & 13.1 & 1.141 & - \\
\hline 1390 & 0.560 & 1.105 & 1.07 & 9.13 & 12.2 & 1.440 & - \\
\hline 1400 & 0.523 & 1.006 & 1.05 & 8.54 & 14.0 & 1.254 & - \\
\hline 1410 & 0.546 & 1.149 & 1.01 & 9.01 & 15.4 & 1.432 & 0.95 \\
\hline 1420 & 0.537 & 1.080 & 2.22 & 9.36 & 14.6 & 1.431 & 1.12 \\
\hline 1430 & 0.607 & 0.953 & & 9.07 & 14.0 & 1.245 & 0.97 \\
\hline 1440 & 0.530 & 1.098 & 1.00 & 8.86 & 11.4 & 1.342 & 1.30 \\
\hline 1450 & 0.524 & 1.193 & 1.00 & 9.08 & 11.7 & 1.314 & 1.05 \\
\hline 1460 & 0.475 & 1.190 & 1.47 & 9.05 & 10.8 & 1.835 & 0.95 \\
\hline 1470 & 0.469 & 1.186 & & 8.90 & 10.3 & 1.491 & 1.10 \\
\hline 1480 & 0.533 & 1.181 & & 9.48 & 11.8 & 1.294 & 1.07 \\
\hline 1490 & 0.476 & 1.331 & 1.48 & 10.03 & 10.6 & 1.389 & 0.96 \\
\hline 1500 & 0.501 & 1.220 & 1.07 & 9.11 & 9.7 & 1.187 & 0.58 \\
\hline 1510 & 0.772 & 1.304 & 1.09 & 10.00 & 9.9 & 1.229 & 0.74 \\
\hline 1520 & 0.740 & 1.172 & 1.43 & 10.73 & 10.2 & 1.244 & 0.79 \\
\hline 1530 & 0.707 & 1.139 & 1.59 & 10.79 & 11.4 & 1.614 & 0.84 \\
\hline 1540 & 1.699 & 1.779 & 1.94 & 16.13 & 14.8 & 2.242 & 0.94 \\
\hline
\end{tabular}


Table A1 (cont.): Individual Price Indices, 1209-1869

\begin{tabular}{|c|c|c|c|c|c|c|c|}
\hline Decade & $\begin{array}{l}\text { Cheese } \\
\text { (d./1b) }\end{array}$ & $\begin{array}{l}\text { Butter } \\
\text { (d./1b) }\end{array}$ & $\begin{array}{c}\text { Milk } \\
\text { (d./ga ) }\end{array}$ & $\begin{array}{l}\text { Dairy } \\
(1860 \mathrm{~s}= \\
100)\end{array}$ & $\begin{array}{c}\text { Fats } \\
(1860 s= \\
100)\end{array}=$ & $\begin{array}{l}\text { Herring } \\
\text { (s./100) }\end{array}$ & $\begin{array}{l}\text { Salt Cod } \\
\text { (s/fish) }\end{array}$ \\
\hline & & & & & & & \\
\hline 1550 & 2.745 & 3.50 & 3.24 & 29.2 & 27.4 & 2.72 & 1.23 \\
\hline 1560 & 2.551 & 3.12 & 3.77 & 30.3 & 29.9 & 3.03 & 0.94 \\
\hline 1570 & 2.582 & 3.29 & 3.30 & 29.3 & 33.4 & 3.12 & 1.27 \\
\hline 1580 & 2.702 & 3.31 & 3.26 & 30.0 & 38.1 & 2.56 & 1.68 \\
\hline 1590 & 3.897 & 3.70 & 3.64 & 35.1 & 48.2 & 3.12 & 2.10 \\
\hline 1600 & 3.464 & 4.20 & 3.35 & 34.9 & 51.3 & 3.32 & 2.01 \\
\hline 1610 & 3.792 & 4.47 & 4.21 & 40.1 & 54.7 & 3.82 & 2.06 \\
\hline 1620 & 3.796 & 4.38 & 4.63 & 41.0 & 51.9 & 4.43 & 2.16 \\
\hline 1630 & 4.255 & 4.95 & 4.64 & 44.5 & 56.0 & 3.79 & 3.07 \\
\hline 1640 & 4.663 & 5.28 & 5.05 & 48.3 & 58.2 & 5.77 & 3.07 \\
\hline 1650 & 3.701 & 5.72 & 6.42 & 50.2 & 61.5 & 3.39 & 2.87 \\
\hline 1660 & 3.922 & 5.72 & 5.97 & 50.7 & 63.3 & - & 3.09 \\
\hline 1670 & 3.989 & 5.64 & 6.29 & 52.9 & 58.5 & - & 3.08 \\
\hline 1680 & 3.081 & 5.37 & 8.65 & 53.3 & 54.9 & 3.75 & 3.25 \\
\hline 1690 & 3.683 & 5.54 & 5.59 & 48.4 & 56.6 & 4.43 & 4.19 \\
\hline 1700 & 2.962 & 5.12 & 5.43 & 44.1 & 54.6 & - & 5.06 \\
\hline 1710 & 3.124 & 4.86 & 5.10 & 42.5 & 54.5 & - & 5.19 \\
\hline 1720 & 3.094 & 4.96 & 5.54 & 44.2 & 56.2 & - & 4.81 \\
\hline 1730 & 2.870 & 5.22 & 5.24 & 43.6 & 55.4 & - & 4.04 \\
\hline 1740 & 3.113 & 5.87 & 5.17 & 46.5 & 57.6 & 2.67 & 3.84 \\
\hline 1750 & 3.095 & 6.31 & 5.11 & 47.7 & 55.6 & - & 3.88 \\
\hline 1760 & 3.256 & 6.37 & 5.34 & 49.2 & 56.0 & 2.50 & 4.72 \\
\hline 1770 & 3.871 & 6.79 & 6.70 & 56.8 & 57.8 & 5.00 & 5.09 \\
\hline 1780 & 3.741 & 6.73 & 7.51 & 58.5 & 58.2 & - & 4.96 \\
\hline 1790 & 4.505 & 7.85 & 8.73 & 68.6 & 53.9 & - & 5.12 \\
\hline 1800 & 6.901 & 10.99 & 12.27 & 98.0 & 78.9 & - & 6.59 \\
\hline 1810 & 7.411 & 12.95 & 16.34 & 118.1 & 87.6 & - & 7.77 \\
\hline 1820 & 6.370 & 10.41 & 15.89 & 103.0 & 82.1 & - & 7.02 \\
\hline 1830 & 5.977 & 10.20 & 13.36 & 94.6 & 80.7 & 4.43 & 6.05 \\
\hline 1840 & 6.228 & 10.32 & 11.87 & 92.2 & 84.9 & 4.03 & - \\
\hline 1850 & 5.933 & 10.20 & 9.79 & 84.9 & 89.6 & 4.60 & 5.25 \\
\hline 1860 & 6.851 & 11.88 & 11.86 & 100.0 & 100.0 & 5.45 & - \\
\hline
\end{tabular}


Table A1 (cont.): Individual Price Indices, 1209-1869

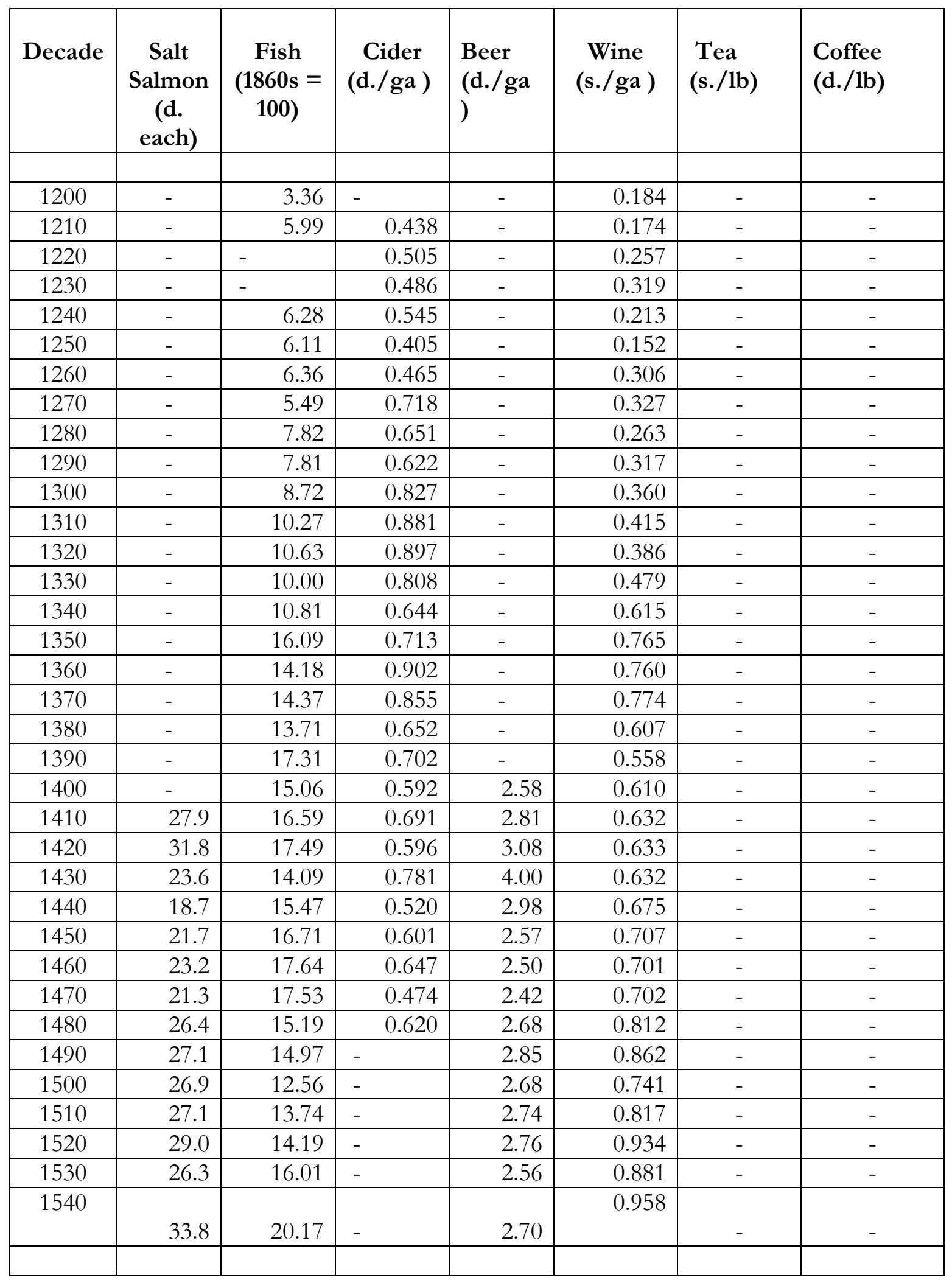


Table A1 (cont.): Individual Price Indices, 1209-1869

\begin{tabular}{|c|c|c|c|c|c|c|c|}
\hline Decade & $\begin{array}{c}\text { Salt } \\
\text { Salmon } \\
\text { (d. } \\
\text { each) }\end{array}$ & $\begin{array}{c}\text { Fish } \\
(1860 \mathrm{~s}= \\
100)\end{array}$ & $\begin{array}{c}\text { Cider } \\
\text { (d./ga ) }\end{array}$ & $\begin{array}{l}\text { Beer } \\
\text { (d./ga ) }\end{array}$ & $\begin{array}{l}\text { Wine } \\
\text { (s./ga ) }\end{array}$ & $\begin{array}{l}\text { Tea } \\
\text { (s./1b) }\end{array}$ & $\begin{array}{l}\text { Coffee } \\
\text { (d./lb) }\end{array}$ \\
\hline 1550 & 48.1 & 27.8 & - & 314 & 110 & - & \\
\hline 1560 & 58.5 & 27.5 & - & 3.58 & 1.35 & - & - \\
\hline 1570 & 70.5 & 31.8 & - & 3.71 & 1.58 & - & - \\
\hline 1580 & 65.8 & 32.5 & - & 3.80 & 1.99 & - & - \\
\hline 1590 & - & 40.2 & - & 4.84 & 2.45 & - & - \\
\hline 1600 & - & 40.9 & - & 5.51 & 2.35 & - & - \\
\hline 1610 & - & 44.5 & - & 5.85 & 2.62 & - & - \\
\hline 1620 & - & 49.2 & - & 5.37 & 3.20 & - & - \\
\hline 1630 & - & 53.5 & - & 7.03 & 3.09 & - & - \\
\hline 1640 & - & 54.0 & - & 7.50 & 3.48 & - & - \\
\hline 1650 & - & 48.5 & - & 7.95 & 5.73 & - & - \\
\hline 1660 & - & 51.8 & - & 8.09 & 5.09 & - & - \\
\hline 1670 & - & 51.6 & - & 8.12 & 5.85 & 37.24 & - \\
\hline 1680 & - & 54.2 & - & 8.22 & 6.34 & 22.33 & 53.34 \\
\hline 1690 & - & 66.3 & - & 10.00 & 6.89 & 45.77 & - \\
\hline 1700 & - & 78.6 & - & 9.75 & 8.67 & 22.14 & 89.50 \\
\hline 1710 & - & 80.6 & - & 10.16 & 7.63 & 26.40 & 58.68 \\
\hline 1720 & - & 74.6 & - & 10.87 & 6.86 & 17.43 & 61.07 \\
\hline 1730 & - & $\begin{array}{l}62.7 \\
\end{array}$ & - & 10.72 & 7.94 & 14.21 & 62.77 \\
\hline 1740 & - & 57.9 & - & 10.91 & 7.33 & 12.68 & 66.16 \\
\hline 1750 & - & 55.5 & - & 10.94 & 7.59 & 10.73 & - \\
\hline 1760 & - & 67.5 & - & 10.56 & 9.03 & 8.93 & 64.34 \\
\hline 1770 & - & 74.4 & - & 11.62 & 9.66 & 10.03 & 61.42 \\
\hline 1780 & - & 70.8 & - & 12.17 & 11.88 & 8.07 & 65.24 \\
\hline 1790 & - & 73.0 & - & 12.45 & 13.58 & 6.76 & 60.22 \\
\hline 1800 & - & 94.0 & - & 17.81 & 20.49 & 7.94 & 70.86 \\
\hline 1810 & - & 110.7 & - & 20.71 & 26.29 & 8.00 & 51.30 \\
\hline 1820 & - & 100.1 & - & 19.72 & 21.16 & 7.69 & 50.81 \\
\hline 1830 & - & 82.3 & - & 20.17 & 17.32 & 5.35 & 33.93 \\
\hline 1840 & - & 73.9 & - & 19.15 & 17.16 & 4.71 & 25.59 \\
\hline 1850 & - & 84.5 & - & 18.35 & 18.60 & 4.16 & 20.28 \\
\hline 1860 & - & 100.0 & - & 20.00 & 20.45 & 3.57 & 22.13 \\
\hline & & & & & & & \\
\hline
\end{tabular}


Table A1 (cont.): Individual Price Indices, 1209-1869

\begin{tabular}{|c|c|c|c|c|c|c|c|}
\hline Decade & $\begin{array}{l}\text { Drink } \\
(1860 \mathrm{~s} \\
=100)\end{array}$ & $\begin{array}{l}\text { Honey } \\
\text { (d./ga ) }\end{array}$ & $\begin{array}{c}\text { Current } \\
\text { s/Raisi } \\
\text { ns } \\
\text { (d./lb ) }\end{array}$ & $\begin{array}{l}\text { Sugar } \\
\text { (d./1b ) }\end{array}$ & $\begin{array}{l}\text { Treacle } \\
\text { (d./ga ) }\end{array}$ & $\begin{array}{l}\text { Sugars } \\
(1860 \mathrm{~s}= \\
100)\end{array}$ & $\begin{array}{l}\text { Salt } \\
(1860 \mathrm{~s}= \\
100)\end{array}$ \\
\hline 1200 & 7.54 & - & - & - & - & - & - \\
\hline 1210 & 8.27 & - & - & - & - & - & 13.5 \\
\hline 1220 & 10.40 & 6.07 & - & - & - & - & 13.3 \\
\hline 1230 & 10.74 & - & - & - & - & - & 12.4 \\
\hline 1240 & 9.66 & - & - & - & - & - & 15.7 \\
\hline 1250 & 9.61 & - & - & - & - & - & 16.8 \\
\hline 1260 & 11.38 & 6.59 & 6.48 & 16.49 & - & 39.2 & 17.8 \\
\hline 1270 & 14.56 & 7.88 & - & - & - & 46.8 & 19.4 \\
\hline 1280 & 12.33 & 6.74 & 1.75 & 8.67 & - & 37.8 & 17.6 \\
\hline 1290 & 14.64 & 7.92 & - & 17.26 & - & 43.8 & 22.6 \\
\hline 1300 & 14.44 & 6.99 & 5.29 & 11.25 & - & 42.7 & 18.5 \\
\hline 1310 & 18.43 & 7.95 & - & 6.02 & - & 46.7 & 43.4 \\
\hline 1320 & 16.52 & 7.70 & - & 9.36 & - & 42.9 & 29.3 \\
\hline 1330 & 14.70 & 6.93 & 3.14 & 9.11 & - & 39.3 & 24.6 \\
\hline 1340 & 15.18 & 8.97 & 0.80 & 11.44 & - & 45.1 & 22.4 \\
\hline 1350 & 20.35 & 11.60 & - & 29.93 & - & 63.4 & 53.4 \\
\hline 1360 & 23.05 & 11.93 & - & 13.23 & - & 62.3 & 46.4 \\
\hline 1370 & 21.00 & 13.60 & 2.71 & 14.21 & - & 74.3 & 52.6 \\
\hline 1380 & 15.07 & 10.55 & 3.04 & 11.84 & - & 62.2 & 44.5 \\
\hline 1390 & 16.07 & 11.73 & 2.69 & 19.43 & - & 62.7 & 38.5 \\
\hline 1400 & 16.11 & 13.09 & 3.90 & 15.55 & - & 75.1 & 52.0 \\
\hline 1410 & 16.65 & 12.56 & 2.68 & 11.99 & - & 65.3 & 40.1 \\
\hline 1420 & 16.99 & 11.61 & 3.15 & 40.00 & - & 65.3 & 39.7 \\
\hline 1430 & 18.94 & 11.32 & 3.48 & 22.50 & - & 65.6 & 44.7 \\
\hline 1440 & 17.10 & 11.71 & 2.76 & 19.82 & - & 63.1 & 39.9 \\
\hline 1450 & 16.46 & 12.54 & 1.94 & 16.10 & - & 59.7 & 39.3 \\
\hline 1460 & 16.01 & 12.63 & 2.32 & 13.12 & - & 62.7 & 33.2 \\
\hline 1470 & 15.38 & 15.25 & 2.50 & 10.08 & - & 69.1 & 32.8 \\
\hline 1480 & 17.11 & 15.17 & 2.17 & 4.99 & - & 63.1 & 44.8 \\
\hline 1490 & 18.23 & 14.41 & 1.63 & 4.88 & - & 53.3 & 39.6 \\
\hline 1500 & 16.76 & 16.58 & 1.55 & 3.00 & - & 49.6 & 38.9 \\
\hline 1510 & 17.42 & 17.63 & 1.27 & 5.10 & - & 55.0 & 45.2 \\
\hline 1520 & 18.14 & 17.28 & 1.87 & 5.91 & - & 66.2 & 53.0 \\
\hline 1530 & 16.96 & 18.74 & 1.80 & 7.21 & - & 73.4 & 53.1 \\
\hline 1540 & 17.98 & 12.43 & 2.42 & 10.01 & - & 97.8 & 60.9 \\
\hline
\end{tabular}


Table A1 (cont.): Individual Price Indices, 1209-1869

\begin{tabular}{|c|c|c|c|c|c|c|c|}
\hline Decade & $\begin{array}{c}\text { Drink } \\
(1860 \mathrm{~s}= \\
100)\end{array}$ & $\begin{array}{l}\text { Honey } \\
\text { (d./ga ) }\end{array}$ & $\begin{array}{l}\text { Currents } \\
\text { /Raisins } \\
\text { (d./lb ) }\end{array}$ & $\begin{array}{l}\text { Sugar } \\
\text { (d./1b ) }\end{array}$ & $\begin{array}{l}\text { Treacle } \\
\text { (d./ga ) }\end{array}$ & $\begin{array}{l}\text { Sugars } \\
(1860 \mathrm{~s}= \\
100)\end{array}$ & $\begin{array}{l}\text { Salt } \\
(1860 \mathrm{~s}= \\
100)\end{array}$ \\
\hline & & & & & & & \\
\hline 1550 & 21.3 & - & 3.29 & 12.81 & - & 132.3 & 78.3 \\
\hline 1560 & 24.2 & - & 3.04 & 11.24 & - & 118.9 & 84.2 \\
\hline 1570 & 25.8 & 40.4 & 3.92 & 13.25 & - & 145.0 & 120.1 \\
\hline 1580 & 27.9 & 61.0 & 3.58 & 16.01 & - & 153.7 & 111.0 \\
\hline 1590 & 34.7 & 53.6 & 4.13 & 12.24 & - & 144.7 & 138.0 \\
\hline 1600 & 38.4 & 60.7 & 4.50 & 16.16 & - & 173.8 & 120.2 \\
\hline 1610 & 41.7 & 70.8 & 4.73 & 15.01 & - & 171.6 & 115.1 \\
\hline 1620 & 40.9 & 53.1 & 4.29 & 13.77 & - & 155.7 & 139.8 \\
\hline 1630 & 48.6 & & 4.38 & 17.96 & - & 180.9 & 188.7 \\
\hline 1640 & 53.0 & 86.0 & 5.00 & 16.51 & - & 186.0 & 204.5 \\
\hline 1650 & 63.3 & - & 6.77 & 15.58 & - & 206.9 & 192.8 \\
\hline 1660 & 62.0 & - & 5.56 & 9.14 & - & 144.3 & 174.7 \\
\hline 1670 & 64.7 & - & 5.53 & 8.01 & - & 135.8 & 184.7 \\
\hline 1680 & 66.5 & - & 5.18 & 7.46 & - & 126.8 & 178.1 \\
\hline 1690 & 78.2 & 159.1 & 5.69 & 8.11 & - & 138.3 & 258.6 \\
\hline 1700 & 80.5 & 73.8 & 5.70 & 7.77 & - & 135.7 & 472.9 \\
\hline 1710 & 84.7 & - & 5.52 & 6.93 & - & 126.2 & 447.1 \\
\hline 1720 & 85.8 & - & 5.33 & 6.60 & - & 121.0 & 434.4 \\
\hline 1730 & 82.6 & - & 5.11 & 6.24 & - & 115.3 & 359.4 \\
\hline 1740 & 82.9 & 44.8 & 5.36 & 6.70 & - & 122.2 & 392.1 \\
\hline 1750 & 81.9 & 10.1 & 4.95 & 6.66 & - & 117.2 & 383.9 \\
\hline 1760 & 79.5 & 47.7 & 5.24 & 6.52 & - & 119.2 & 385.4 \\
\hline 1770 & 86.9 & 63.7 & 5.35 & 6.70 & 1.25 & 122.3 & 385.4 \\
\hline 1780 & 91.7 & - & 5.72 & 7.19 & 1.29 & 130.4 & 486.0 \\
\hline 1790 & 91.3 & - & 7.16 & 9.40 & 1.28 & 163.8 & 622.3 \\
\hline 1800 & 125.6 & - & 9.46 & 10.15 & 1.26 & 184.8 & $1,340.9$ \\
\hline 1810 & 140.4 & - & 9.59 & 10.65 & 1.28 & 191.4 & $1,617.6$ \\
\hline 1820 & 130.9 & - & 8.80 & 8.36 & 1.28 & 160.1 & 624.4 \\
\hline 1830 & 112.7 & - & 6.61 & 7.96 & 1.28 & 144.4 & 155.0 \\
\hline 1840 & 104.4 & - & 5.72 & 7.25 & 1.28 & 130.8 & 140.5 \\
\hline 1850 & 98.4 & - & 6.65 & 5.31 & 1.29 & 111.0 & 83.2 \\
\hline 1860 & 100.0 & - & 5.06 & 4.98 & 1.33 & 100.0 & 100.0 \\
\hline
\end{tabular}


Table A1 (cont.): Individual Price Indices, 1209-1869

\begin{tabular}{|c|c|c|c|c|c|c|c|}
\hline Decade & $\begin{array}{l}\text { Ginger } \\
\text { (d./1b) }\end{array}$ & $\begin{array}{c}\text { Mace } \\
\text { (s./1b) }\end{array}$ & $\begin{array}{l}\text { Cinnam } \\
\text { on } \\
(s . / 1 b)\end{array}$ & $\begin{array}{l}\text { Pepper } \\
\text { (d./1b) }\end{array}$ & $\begin{array}{l}\text { Spices } \\
(1860 \mathrm{~s}= \\
100)\end{array}$ & $\begin{array}{l}\text { Food DE } \\
(1860 \mathrm{~s}= \\
100)\end{array}$ & $\begin{array}{l}\text { Food COL } \\
(1860 \mathrm{~s}= \\
100)\end{array}$ \\
\hline & & & & & & & \\
\hline 1200 & & & & & & 5.05 & 4.78 \\
\hline 1210 & & & & 5.93 & 21.7 & 6.05 & 5.79 \\
\hline 1220 & & & & 9.08 & 33.3 & 7.09 & 6.82 \\
\hline 1230 & & & & & & 7.20 & 6.85 \\
\hline 1240 & & & & 14.30 & 52.4 & 7.30 & 6.97 \\
\hline 1250 & & & & 6.64 & 24.3 & 7.62 & 7.33 \\
\hline 1260 & 24.0 & & 0.75 & 9.07 & 42.8 & 7.87 & 7.50 \\
\hline 1270 & & & & 10.53 & 47.2 & 10.10 & 9.71 \\
\hline 1280 & 18.7 & 1.69 & & 9.14 & 43.1 & 8.93 & 8.59 \\
\hline 1290 & & 2.50 & & 12.69 & 56.8 & 10.47 & 10.10 \\
\hline 1300 & & & & 10.96 & 51.1 & 9.54 & 9.13 \\
\hline 1310 & 14.0 & & & 11.26 & 51.7 & 13.03 & 12.62 \\
\hline 1320 & 16.0 & & 1.61 & 12.52 & 55.5 & 11.88 & 11.42 \\
\hline 1330 & 19.4 & 2.18 & 1.79 & 12.40 & 57.2 & 9.87 & 9.43 \\
\hline 1340 & 30.4 & & 1.39 & 13.59 & 63.2 & 9.51 & 9.04 \\
\hline 1350 & 18.0 & & & 22.81 & 97.5 & 12.25 & 11.68 \\
\hline 1360 & 16.0 & & & 13.87 & 70.8 & 12.84 & 12.22 \\
\hline 1370 & 18.2 & 4.17 & & 16.76 & 79.2 & 13.20 & 12.60 \\
\hline 1380 & 17.0 & & & 10.96 & 49.6 & 10.27 & 9.76 \\
\hline 1390 & 36.5 & & 2.00 & 13.92 & 63.8 & 10.67 & 10.13 \\
\hline 1400 & 23.6 & 2.44 & 1.13 & 10.77 & 52.7 & 11.13 & 10.62 \\
\hline 1410 & 30.2 & 2.31 & & 21.26 & 84.5 & 11.43 & 10.88 \\
\hline 1420 & 32.0 & 2.11 & & 16.40 & 72.8 & 10.37 & 9.80 \\
\hline 1430 & 24.4 & 2.00 & 2.33 & 13.48 & 59.4 & 11.95 & 11.42 \\
\hline 1440 & 14.8 & 2.38 & 1.50 & 8.71 & 45.3 & 10.09 & 9.56 \\
\hline 1450 & 14.9 & 2.37 & 2.50 & 10.50 & 50.1 & 10.50 & 9.98 \\
\hline 1460 & 16.1 & 2.18 & 1.46 & 12.77 & 55.2 & 10.71 & 10.16 \\
\hline 1470 & 20.0 & 2.32 & 1.63 & 13.27 & 60.7 & 10.84 & 10.28 \\
\hline 1480 & 45.3 & 2.06 & 3.31 & 15.12 & 69.4 & 11.84 & 11.28 \\
\hline 1490 & 27.5 & 2.68 & 3.45 & 11.97 & 66.8 & 10.90 & 10.31 \\
\hline 1500 & 20.8 & 2.97 & 2.29 & 16.68 & 74.7 & 11.40 & 10.84 \\
\hline 1510 & 46.0 & 3.16 & 3.19 & 13.30 & 78.1 & 11.72 & 11.09 \\
\hline 1520 & 33.2 & 3.95 & 5.21 & 20.21 & 102.4 & 14.24 & 13.58 \\
\hline 1530 & 27.4 & 4.50 & 5.50 & 20.88 & 105.9 & 15.07 & 14.42 \\
\hline 1540 & 37.0 & 2.99 & 5.53 & 21.98 & 116.7 & 17.36 & 16.56 \\
\hline
\end{tabular}


Table A1 (cont.): Individual Price Indices, 1209-1869

\begin{tabular}{|c|c|c|c|c|c|c|c|}
\hline Decade & $\begin{array}{l}\text { Ginger } \\
\text { (d./1b) }\end{array}$ & $\begin{array}{l}\text { Mace } \\
\text { (s./1b) }\end{array}$ & $\begin{array}{l}\text { Cinnamo } \\
\text { n (s./1b) }\end{array}$ & $\begin{array}{c}\text { Pepper } \\
\text { (d./1b) }\end{array}$ & $\begin{array}{l}\text { Spices } \\
(1860 \mathrm{~s}= \\
100)\end{array}=$ & $\begin{array}{l}\text { Food } \\
\text { DE } \\
(1860 \mathrm{~s}= \\
100)\end{array}$ & $\begin{array}{l}\text { Food } \\
\text { COL } \\
(1860 \mathrm{~s}= \\
100)\end{array}$ \\
\hline 1550 & 521 & 827 & 504 & 2873 & 1425 & 276 & 266 \\
\hline 1560 & 48.9 & 6.40 & 14.05 & 36.89 & 184.9 & 27.7 & 26.5 \\
\hline 1570 & 53.7 & 7.05 & 6.24 & 30.70 & 155.2 & 30.1 & 28.9 \\
\hline 1580 & 44.8 & 6.81 & 7.62 & 37.39 & 169.0 & 33.8 & 32.7 \\
\hline 1590 & 32.4 & 6.26 & 5.84 & 40.68 & 159.7 & 45.6 & 44.7 \\
\hline 1600 & 22.7 & 5.19 & 4.28 & 30.67 & 117.5 & 45.8 & 44.8 \\
\hline 1610 & 22.6 & 4.80 & 4.51 & 25.58 & 109.2 & 52.5 & 51.7 \\
\hline 1620 & 18.5 & 5.61 & 4.04 & 22.12 & 99.5 & 52.2 & 51.4 \\
\hline 1630 & 20.7 & 6.27 & 5.35 & 21.06 & 107.9 & 61.7 & 60.9 \\
\hline 1640 & 24.0 & 6.86 & 9.37 & 25.04 & 136.3 & 63.3 & 62.2 \\
\hline 1650 & 17.3 & 7.34 & 4.00 & 19.14 & 108.5 & 63.2 & 61.9 \\
\hline 1660 & 13.7 & 6.51 & 12.29 & 15.62 & 96.1 & 62.5 & 62.0 \\
\hline 1670 & 11.8 & 6.29 & 9.23 & 15.30 & 89.2 & 61.3 & 60.7 \\
\hline 1680 & 12.3 & 7.11 & 11.34 & 16.53 & 98.5 & 57.8 & 56.7 \\
\hline 1690 & 15.7 & 9.57 & 9.89 & 23.33 & 124.6 & 66.9 & 66.2 \\
\hline 1700 & 15.3 & 9.61 & 9.31 & 18.33 & 109.4 & 58.5 & 56.9 \\
\hline 1710 & 14.2 & 11.06 & 9.11 & 33.67 & 149.0 & 64.6 & 63.8 \\
\hline 1720 & 11.1 & 10.22 & 9.36 & 26.66 & 125.6 & 63.5 & 62.8 \\
\hline 1730 & 12.1 & 9.17 & 9.47 & 20.20 & 109.9 & 56.3 & 55.1 \\
\hline 1740 & 10.8 & 9.36 & 9.97 & 21.79 & 113.4 & 58.1 & 56.7 \\
\hline 1750 & 12.9 & 8.92 & 12.56 & 22.25 & 121.4 & 63.0 & 62.2 \\
\hline 1760 & 12.5 & 8.80 & 15.08 & 22.75 & 125.4 & 66.6 & 66.1 \\
\hline 1770 & 13.0 & 8.59 & 18.58 & 23.92 & 133.5 & 75.2 & 74.8 \\
\hline 1780 & 14.7 & 13.20 & 22.09 & 23.95 & 149.5 & 77.9 & 77.2 \\
\hline 1790 & 21.8 & 22.39 & 24.00 & 27.25 & 184.7 & 90.4 & 89.9 \\
\hline 1800 & 30.8 & 25.32 & 19.63 & 32.82 & 214.8 & 127.9 & 127.8 \\
\hline 1810 & 42.2 & 21.80 & 19.77 & 40.59 & 247.6 & 142.7 & 142.1 \\
\hline 1820 & 46.3 & 9.07 & 16.00 & 38.11 & 205.7 & 110.8 & 109.8 \\
\hline 1830 & 29.8 & 8.49 & 13.27 & 23.18 & 142.4 & 100.6 & 100.6 \\
\hline 1840 & 30.8 & 10.66 & 11.48 & 19.59 & 134.8 & 99.5 & 100.3 \\
\hline 1850 & 31.0 & 7.30 & 9.36 & 17.46 & 116.0 & 95.1 & 95.8 \\
\hline 1860 & & 5.28 & 4.68 & 15.18 & 100.0 & 100.0 & 100.0 \\
\hline
\end{tabular}


Table A1 (cont.): Individual Price Indices, 1209-1869

\begin{tabular}{|c|c|c|c|c|c|c|c|}
\hline Decade & $\begin{array}{l}\text { Firewood } \\
\text { (s./ton) }\end{array}$ & $\begin{array}{c}\text { Charcoal } \\
\text { (s./bu) }\end{array}$ & $\begin{array}{l}\text { Coal } \\
\text { (s./ } \\
\text { ton) }\end{array}$ & $\begin{array}{c}\text { Fuel } \\
(1860 \mathrm{~s} \\
=100)\end{array}$ & $\begin{array}{l}\text { House } \\
\text { Rent } \\
\text { (index) }\end{array}$ & $\begin{array}{l}\text { Tallow } \\
\text { Candles } \\
\text { (d./1b.) }\end{array}$ & $\begin{array}{l}\text { Wax } \\
\text { Candles } \\
\text { (d./lb.) }\end{array}$ \\
\hline 1200 & - & - & - & - & - & - & - \\
\hline 1210 & - & - & - & - & - & - & - \\
\hline 1220 & - & - & - & - & - & - & 3.57 \\
\hline 1230 & - & - & - & - & - & - & - \\
\hline 1240 & - & - & - & - & - & - & 4.15 \\
\hline 1250 & 2.29 & 0.29 & - & 10.21 & - & - & - \\
\hline 1260 & 2.63 & - & - & 12.19 & 6.60 & - & 4.03 \\
\hline 1270 & 3.91 & 0.61 & - & 18.38 & - & - & 3.78 \\
\hline 1280 & 2.79 & 0.45 & 1.42 & 12.78 & 8.35 & 1.26 & 3.36 \\
\hline 1290 & 2.99 & 0.59 & 1.47 & 13.84 & 9.40 & 1.54 & 4.24 \\
\hline 1300 & 3.05 & 0.55 & 1.41 & 14.10 & 11.04 & 1.94 & 3.93 \\
\hline 1310 & 3.41 & 0.67 & 1.58 & 15.83 & 9.63 & 2.04 & 3.90 \\
\hline 1320 & 2.98 & 0.72 & 1.52 & 14.62 & 8.49 & 2.15 & 3.85 \\
\hline 1330 & 3.05 & 0.65 & 1.88 & 15.06 & 7.49 & 1.85 & 4.04 \\
\hline 1340 & 2.53 & 0.64 & 1.44 & 12.73 & 7.25 & 1.71 & 3.48 \\
\hline 1350 & 4.64 & 1.90 & 2.23 & 23.65 & 3.90 & 2.10 & 3.59 \\
\hline 1360 & 4.20 & 1.40 & 1.72 & 20.51 & 3.82 & 2.21 & 4.17 \\
\hline 1370 & 4.38 & 1.42 & 1.65 & 20.77 & 3.65 & 2.14 & 2.88 \\
\hline 1380 & 4.06 & 1.06 & 1.15 & 17.92 & 3.99 & 2.02 & 4.02 \\
\hline 1390 & 4.37 & 1.07 & 1.58 & 20.00 & 4.42 & 1.81 & 3.43 \\
\hline 1400 & 4.36 & 1.19 & 3.56 & 23.79 & 4.99 & 1.85 & 3.18 \\
\hline 1410 & 4.17 & 1.06 & 2.83 & 21.68 & 5.09 & 1.72 & 3.88 \\
\hline 1420 & 4.79 & 1.04 & 2.21 & 22.57 & 4.79 & 1.63 & 3.73 \\
\hline 1430 & 4.50 & 1.11 & 2.45 & 22.38 & 4.33 & 1.62 & 3.31 \\
\hline 1440 & 4.29 & 1.10 & 2.49 & 21.71 & 3.90 & 1.58 & 4.04 \\
\hline 1450 & 4.44 & 1.20 & 2.28 & 22.14 & 3.84 & 1.33 & 3.82 \\
\hline 1460 & 4.21 & 1.11 & 2.39 & 21.32 & 3.89 & 1.37 & 4.35 \\
\hline 1470 & 4.08 & 0.97 & 2.46 & 20.45 & 4.04 & 1.33 & 4.56 \\
\hline 1480 & 3.63 & 1.03 & 2.07 & 18.70 & 4.16 & 1.32 & 4.56 \\
\hline 1490 & 3.77 & 1.01 & 1.97 & 18.84 & 4.13 & 1.17 & 4.57 \\
\hline 1500 & 3.41 & 1.03 & 2.14 & 18.02 & 4.23 & 1.14 & 4.10 \\
\hline 1510 & 3.61 & 1.16 & 1.90 & 18.58 & 4.33 & 1.24 & 4.54 \\
\hline 1520 & 3.68 & 1.21 & 2.84 & 20.50 & 4.71 & 1.25 & 4.95 \\
\hline 1530 & 3.74 & 1.19 & 2.36 & 19.85 & 4.80 & 1.38 & 4.36 \\
\hline 1540 & 4.05 & 1.39 & 2.65 & 21.98 & 5.52 & 1.57 & 3.38 \\
\hline
\end{tabular}


Table A1 (cont.): Individual Price Indices, 1209-1869

\begin{tabular}{|c|c|c|c|c|c|c|c|}
\hline Decade & $\begin{array}{l}\text { Firewoo } \\
\text { d } \\
\text { (s./ton) }\end{array}$ & $\begin{array}{c}\text { Charcoal } \\
\text { (s./bu) }\end{array}$ & $\begin{array}{l}\text { Coal } \\
\text { (s./ton) }\end{array}$ & $\begin{array}{c}\text { Fuel } \\
(1860 s= \\
100)\end{array}=$ & $\begin{array}{l}\text { House } \\
\text { Rent } \\
\text { (index) }\end{array}$ & $\begin{array}{l}\text { Tallow } \\
\text { Candles } \\
\text { (d./lb.) }\end{array}$ & $\begin{array}{l}\text { Wax } \\
\text { Candles } \\
\text { (d./lb.) }\end{array}$ \\
\hline & & & & & & & \\
\hline 1550 & 5.14 & 2.08 & 4.08 & 29.7 & 6.9 & 2.24 & 6.83 \\
\hline 1560 & 5.29 & 2.40 & 4.35 & 31.4 & 8.8 & 2.88 & 6.27 \\
\hline 1570 & 6.45 & 2.59 & 4.92 & 37.0 & 11.0 & 2.96 & 6.52 \\
\hline 1580 & 7.65 & 2.98 & 5.84 & 43.8 & 13.5 & 3.22 & 6.35 \\
\hline 1590 & 8.35 & 3.03 & 6.33 & 47.3 & 15.7 & 4.02 & 6.79 \\
\hline 1600 & 10.63 & 3.13 & 6.95 & 56.2 & 17.0 & 4.20 & 7.92 \\
\hline 1610 & 11.49 & 4.20 & 7.19 & 62.0 & 20.6 & 4.56 & - \\
\hline 1620 & 11.76 & 4.28 & 7.49 & 63.7 & 20.6 & 4.64 & - \\
\hline 1630 & 13.10 & 4.21 & 8.73 & 70.5 & 24.2 & 4.89 & 10.76 \\
\hline 1640 & 15.36 & 5.33 & 11.63 & 85.9 & 19.3 & 5.47 & 9.93 \\
\hline 1650 & 13.77 & 6.22 & 10.48 & 80.6 & 19.5 & 5.39 & 13.06 \\
\hline 1660 & 14.85 & 6.94 & 10.61 & 85.9 & 22.5 & 5.62 & 14.59 \\
\hline 1670 & 15.96 & 7.11 & 10.45 & 89.7 & 27.0 & 5.24 & 15.45 \\
\hline 1680 & 16.13 & 7.51 & 9.05 & 87.9 & 29.6 & 4.88 & 12.26 \\
\hline 1690 & 15.82 & 7.61 & 11.92 & 93.3 & 26.6 & 5.48 & 14.54 \\
\hline 1700 & 15.46 & 7.86 & 12.39 & 94.1 & 32.2 & 4.95 & 14.44 \\
\hline 1710 & 15.84 & 7.88 & 11.75 & 93.3 & 28.7 & 6.08 & 18.39 \\
\hline 1720 & 15.14 & 7.55 & 11.24 & 89.2 & 32.3 & 5.76 & 19.61 \\
\hline 1730 & 14.90 & 8.38 & 11.67 & 91.0 & 31.5 & 5.42 & 20.53 \\
\hline 1740 & 14.34 & 9.28 & 12.24 & 92.2 & 29.6 & 6.54 & 20.69 \\
\hline 1750 & 13.91 & 9.39 & 12.69 & 92.2 & 30.5 & 6.33 & 21.53 \\
\hline 1760 & 14.43 & 10.04 & 13.20 & 96.1 & 34.7 & 6.82 & 22.26 \\
\hline 1770 & 17.41 & 10.15 & 13.53 & 103.7 & 38.3 & 7.15 & 24.05 \\
\hline 1780 & 14.55 & 9.92 & 14.02 & 99.9 & 38.7 & 7.54 & 26.19 \\
\hline 1790 & 14.37 & 9.83 & 16.78 & 110.5 & 49.5 & 8.36 & 31.37 \\
\hline 1800 & 16.88 & 11.06 & 23.33 & 143.4 & 70.9 & 10.73 & 49.47 \\
\hline 1810 & 20.91 & 11.58 & 26.18 & 165.1 & 85.3 & 11.46 & 54.14 \\
\hline 1820 & 20.36 & 12.50 & 22.71 & 151.3 & 86.8 & 7.13 & 46.38 \\
\hline 1830 & 19.63 & 13.82 & 18.52 & 128.2 & 85.2 & 6.18 & 34.27 \\
\hline 1840 & 17.56 & 12.63 & 16.30 & 113.4 & 83.8 & 5.93 & 29.79 \\
\hline 1850 & 16.73 & 10.66 & 13.73 & 97.4 & 89.5 & 6.27 & 29.04 \\
\hline 1860 & 18.28 & 11.26 & 13.93 & 100.0 & 100.0 & 6.40 & 35.99 \\
\hline
\end{tabular}


Table A1 (cont.): Individual Price Indices, 1209-1869

\begin{tabular}{|c|c|c|c|c|c|c|c|}
\hline Decade & $\begin{array}{l}\text { Lamp } \\
\text { Oil } \\
\text { (d./ga.) }\end{array}$ & $\begin{array}{l}\text { Coalgas } \\
\text { (s./100 } \\
\text { ft cu.) }\end{array}$ & $\begin{array}{l}\text { Light } \\
(1860 \mathrm{~s} \\
=100)\end{array}$ & $\begin{array}{c}\text { Soap } \\
\text { (d./lb.) }\end{array}$ & $\begin{array}{l}\text { Shoes } \\
\text { (s./pair) }\end{array}$ & $\begin{array}{l}\text { Gloves } \\
\text { (d./pair) }\end{array}$ & $\begin{array}{l}\begin{array}{l}\text { Leather } \\
\text { Goods }\end{array} \\
(1860 \mathrm{~s}= \\
100)\end{array}$ \\
\hline 1200 & - & - & 14.09 & - & - & - & - \\
\hline 1210 & - & - & 12.60 & - & - & - & - \\
\hline 1220 & - & - & 26.55 & - & - & - & - \\
\hline 1230 & - & - & 21.69 & - & - & - & - \\
\hline 1240 & - & - & 18.98 & - & - & - & - \\
\hline 1250 & - & - & 18.59 & - & - & 1.67 & 14.7 \\
\hline 1260 & - & - & 21.44 & - & - & - & - \\
\hline 1270 & 5.49 & - & 22.13 & 0.57 & - & - & - \\
\hline 1280 & - & - & 18.84 & 0.79 & - & 1.70 & 15.0 \\
\hline 1290 & 10.57 & - & 22.03 & 1.19 & - & 1.50 & 11.9 \\
\hline 1300 & 5.74 & - & 25.52 & 1.08 & - & 1.50 & 13.2 \\
\hline 1310 & 8.67 & - & 27.08 & 0.85 & - & 1.49 & 13.1 \\
\hline 1320 & 8.44 & - & 27.76 & 1.20 & - & 1.57 & 13.9 \\
\hline 1330 & 6.99 & - & 24.56 & 1.21 & - & 1.63 & 14.4 \\
\hline 1340 & 9.06 & - & 23.37 & 1.16 & - & 2.00 & 17.6 \\
\hline 1350 & 11.50 & - & 28.08 & 1.02 & - & 2.06 & 18.2 \\
\hline 1360 & 11.11 & - & 29.50 & - & - & 2.03 & 17.9 \\
\hline 1370 & 12.03 & - & 27.62 & 1.14 & - & 1.99 & 17.5 \\
\hline 1380 & 11.49 & - & 27.50 & - & - & 1.91 & 16.8 \\
\hline 1390 & 10.71 & - & 24.61 & - & - & 1.92 & 17.0 \\
\hline 1400 & 11.04 & - & 25.05 & - & - & 1.25 & 11.0 \\
\hline 1410 & 10.67 & - & 24.23 & - & - & 1.26 & 11.1 \\
\hline 1420 & 10.27 & - & 23.00 & 1.32 & - & 1.75 & 15.4 \\
\hline 1430 & 10.13 & - & 22.38 & 1.52 & - & 1.67 & 14.7 \\
\hline 1440 & 11.03 & - & 22.75 & 1.78 & - & 1.60 & 14.1 \\
\hline 1450 & 9.53 & - & 19.67 & 1.84 & 0.445 & 1.40 & 11.8 \\
\hline 1460 & 9.08 & - & 20.28 & 1.65 & - & - & - \\
\hline 1470 & 9.97 & - & 20.22 & 1.49 & 0.445 & 1.00 & 7.8 \\
\hline 1480 & 9.48 & - & 20.03 & 1.48 & 0.334 & - & 5.0 \\
\hline 1490 & 10.68 & - & 18.57 & 1.74 & - & 1.75 & 10.3 \\
\hline 1500 & 10.72 & - & 17.87 & 1.41 & 0.383 & 1.47 & 9.0 \\
\hline 1510 & 10.82 & - & 19.45 & 1.74 & 0.358 & 1.00 & 7.1 \\
\hline 1520 & 10.90 & - & 19.71 & 2.01 & - & 1.00 & 8.8 \\
\hline 1530 & 11.14 & - & 20.89 & 2.59 & 0.452 & & 6.8 \\
\hline 1540 & 11.81 & - & 22.54 & 1.91 & 0.914 & 1.50 & 13.5 \\
\hline
\end{tabular}


Table A1 (cont.): Individual Price Indices, 1209-1869

\begin{tabular}{|c|c|c|c|c|c|c|c|}
\hline Decade & $\begin{array}{l}\text { Lamp } \\
\text { Oil } \\
\text { (d./ga.) }\end{array}$ & $\begin{array}{l}\text { Coalgas } \\
\text { (s./100 ft } \\
\text { cu.) }\end{array}$ & $\begin{array}{c}\text { Light } \\
(1860 \mathrm{~s}= \\
100)\end{array}$ & $\begin{array}{c}\text { Soap } \\
\text { (d./lb.) }\end{array}$ & $\begin{array}{l}\text { Shoes } \\
\text { (s./pair) }\end{array}$ & $\begin{array}{l}\text { Gloves } \\
\text { (d./pair } \\
\text { ) }\end{array}$ & $\begin{array}{l}\text { Leather } \\
\text { Goods } \\
(1860 \mathrm{~s}= \\
100)\end{array}$ \\
\hline 1550 & 22.7 & - & 34.4 & 4.06 & 1.00 & 3.50 & 16.4 \\
\hline 1560 & 38.4 & - & 43.2 & 4.02 & 1.30 & - & 19.5 \\
\hline 1570 & 39.9 & - & 44.8 & 3.60 & 1.84 & - & 27.7 \\
\hline 1580 & 47.5 & - & 48.1 & 3.49 & 1.83 & - & 27.6 \\
\hline 1590 & 47.4 & - & 60.0 & 4.10 & 1.68 & - & 25.3 \\
\hline 1600 & 52.1 & - & 63.3 & 3.68 & 1.98 & - & 29.7 \\
\hline 1610 & 55.5 & - & 70.5 & 3.79 & 2.27 & - & 34.1 \\
\hline 1620 & 48.5 & - & 68.8 & 3.78 & 2.30 & - & 34.6 \\
\hline 1630 & 49.0 & - & 72.1 & 4.75 & 2.54 & - & 38.3 \\
\hline 1640 & 48.9 & - & 77.3 & 4.94 & 2.99 & - & 45.0 \\
\hline 1650 & 64.0 & - & 81.5 & 4.71 & 3.33 & - & 50.2 \\
\hline 1660 & 51.9 & - & 83.9 & 4.21 & 3.30 & - & 49.6 \\
\hline 1670 & 46.8 & - & 79.1 & 3.71 & 2.88 & - & 43.4 \\
\hline 1680 & 48.0 & - & 74.0 & 3.97 & 2.84 & - & 42.8 \\
\hline 1690 & 66.6 & - & 84.2 & 5.80 & 3.12 & - & 46.9 \\
\hline 1700 & 65.2 & - & 77.8 & 4.38 & 3.06 & 6.00 & 46.1 \\
\hline 1710 & 70.3 & - & 95.0 & 6.03 & 3.35 & - & 50.5 \\
\hline 1720 & 54.2 & - & 89.8 & 6.25 & 3.60 & - & 54.2 \\
\hline 1730 & 53.1 & - & 86.2 & 5.83 & 3.63 & - & 54.7 \\
\hline 1740 & 60.3 & - & 100.8 & 6.81 & 3.67 & 6.50 & 55.2 \\
\hline 1750 & 58.7 & - & 98.5 & 6.41 & 4.04 & 7.00 & 60.8 \\
\hline 1760 & 53.5 & - & 103.8 & 6.99 & 4.01 & - & 60.4 \\
\hline 1770 & 46.1 & - & 107.0 & 7.12 & 3.95 & - & 59.5 \\
\hline 1780 & 56.3 & - & 115.2 & 7.58 & 3.86 & - & 58.0 \\
\hline 1790 & 69.1 & - & 130.7 & 8.94 & 4.20 & - & 63.2 \\
\hline 1800 & 92.0 & - & 173.8 & 11.09 & 5.50 & - & 82.7 \\
\hline 1810 & 106.7 & 15.18 & 186.6 & 12.54 & 5.80 & - & 87.3 \\
\hline 1820 & 75.1 & 13.31 & 124.4 & 9.53 & 5.96 & - & 89.8 \\
\hline 1830 & 79.6 & 10.51 & 118.5 & 6.87 & 5.67 & - & 85.4 \\
\hline 1840 & 83.2 & 7.60 & 107.5 & 6.11 & 5.42 & - & 81.6 \\
\hline 1850 & 73.4 & 4.76 & 97.7 & 5.09 & 5.42 & - & 81.6 \\
\hline 1860 & 97.6 & 4.32 & 100.0 & 4.91 & 6.64 & 10.00 & 100.0 \\
\hline
\end{tabular}


Table A1 (cont.): Individual Price Indices, 1209-1869

\begin{tabular}{|c|c|c|c|c|c|c|c|}
\hline Decade & $\begin{array}{l}\text { Wool } \\
\text { Cloth } \\
\text { (s./yd.) }\end{array}$ & $\begin{array}{l}\text { Linen } \\
\text { Cloth } \\
\text { (d./yd.) }\end{array}$ & $\begin{array}{c}\text { Cotton } \\
\text { Cloth } \\
\text { (s./yd.) }\end{array}$ & $\begin{array}{c}\text { Silk } \\
\text { Thread } \\
\text { (d./lb.) }\end{array}$ & $\begin{array}{l}\text { Stockin } \\
\text { gs } \\
\text { (s./pair) }\end{array}$ & $\begin{array}{l}\text { Suit of } \\
\text { Clothes } \\
\text { (s.) }\end{array}$ & $\begin{array}{l}\text { Clothing } \\
(1860 \mathrm{~s}= \\
100)\end{array}$ \\
\hline 1200 & - & 3.59 & - & - & - & - & 17.30 \\
\hline 1210 & - & 3.57 & - & - & - & - & 17.19 \\
\hline 1220 & - & 3.32 & - & - & - & - & 15.96 \\
\hline 1230 & - & 3.04 & - & - & - & - & 14.79 \\
\hline 1240 & 2.42 & 3.91 & - & - & - & - & 18.17 \\
\hline 1250 & 2.55 & 3.46 & - & - & - & - & 16.62 \\
\hline 1260 & 2.44 & 3.80 & - & - & - & - & 17.96 \\
\hline 1270 & 2.41 & 3.74 & - & - & - & - & 17.36 \\
\hline 1280 & 2.76 & 3.47 & - & 12.24 & - & - & 17.75 \\
\hline 1290 & 2.11 & 4.18 & - & - & - & - & 17.18 \\
\hline 1300 & 2.72 & 4.39 & - & - & - & - & 19.42 \\
\hline 1310 & 3.28 & 4.69 & - & - & - & - & 21.65 \\
\hline 1320 & 2.74 & 4.60 & - & - & - & - & 19.97 \\
\hline 1330 & 2.37 & 4.64 & - & - & - & - & 18.17 \\
\hline 1340 & 2.17 & 4.09 & - & - & - & - & 16.51 \\
\hline 1350 & 2.89 & 8.34 & - & - & - & - & 25.33 \\
\hline 1360 & 2.74 & 9.21 & - & 20.00 & - & - & 25.90 \\
\hline 1370 & 2.91 & 8.83 & - & - & - & - & 26.66 \\
\hline 1380 & 2.73 & 8.69 & - & - & - & - & 25.48 \\
\hline 1390 & 2.52 & 8.20 & - & - & - & - & 24.14 \\
\hline 1400 & 2.58 & 7.55 & - & - & - & - & 23.34 \\
\hline 1410 & 2.73 & 7.03 & - & - & - & - & 23.73 \\
\hline 1420 & 2.59 & 7.22 & - & - & - & - & 23.52 \\
\hline 1430 & 2.55 & 7.38 & - & - & - & - & 23.52 \\
\hline 1440 & 2.52 & 7.12 & - & - & - & - & 23.34 \\
\hline 1450 & 2.33 & 7.12 & - & - & - & - & 22.06 \\
\hline 1460 & 2.55 & 7.06 & - & - & - & - & 22.57 \\
\hline 1470 & 2.55 & 7.43 & - & - & - & - & 22.79 \\
\hline 1480 & 2.69 & 7.05 & - & - & - & - & 22.98 \\
\hline 1490 & 2.60 & 6.70 & - & 12.50 & - & - & 22.71 \\
\hline 1500 & 2.76 & 7.44 & - & 13.78 & - & - & 23.45 \\
\hline 1510 & 2.86 & 6.39 & - & 10.33 & - & - & 23.36 \\
\hline 1520 & 3.00 & 6.89 & - & 8.65 & - & - & 24.59 \\
\hline 1530 & 3.23 & 7.33 & - & 10.29 & - & - & 25.98 \\
\hline 1540 & 3.48 & 7.47 & - & - & - & - & 27.91 \\
\hline
\end{tabular}


Table A1 (cont.): Individual Price Indices, 1209-1869

\begin{tabular}{|c|c|c|c|c|c|c|c|}
\hline Decade & $\begin{array}{l}\text { Wool } \\
\text { Cloth } \\
\text { (s./yd.) }\end{array}$ & $\begin{array}{l}\text { Linen } \\
\text { Cloth } \\
\text { (d./yd.) }\end{array}$ & $\begin{array}{l}\text { Cotton } \\
\text { Cloth } \\
\text { (d./yd.) }\end{array}$ & $\begin{array}{c}\text { Silk } \\
\text { Thread } \\
\text { (d./lb.) }\end{array}$ & $\begin{array}{l}\text { Stockings } \\
\text { (s./pair) }\end{array}$ & $\begin{array}{l}\text { Suit of } \\
\text { Clothes } \\
\text { (s.) }\end{array}$ & $\begin{array}{l}\text { Clothing } \\
(1860 \mathrm{~s}= \\
100)\end{array}$ \\
\hline & & & & & & & \\
\hline 1550 & 4.16 & 10.59 & - & - & - & - & 35.0 \\
\hline 1560 & 5.66 & 11.50 & - & - & - & 9.49 & 42.8 \\
\hline 1570 & 6.03 & 14.05 & - & - & - & 15.06 & 50.0 \\
\hline 1580 & 6.41 & 15.48 & - & 24.00 & - & 15.89 & 53.0 \\
\hline 1590 & 6.73 & 15.91 & - & 24.15 & - & 17.56 & 55.4 \\
\hline 1600 & 7.63 & 16.17 & - & 25.90 & - & 18.43 & 60.4 \\
\hline 1610 & 7.67 & 16.76 & - & 26.64 & - & 21.18 & 65.1 \\
\hline 1620 & 7.71 & 16.84 & - & 29.61 & - & 25.62 & 70.1 \\
\hline 1630 & 8.31 & 17.21 & - & - & 24.84 & 35.19 & 82.0 \\
\hline 1640 & 8.97 & 17.81 & - & - & 25.50 & 40.22 & 90.7 \\
\hline 1650 & 9.08 & 18.49 & - & 30.00 & 30.20 & 36.88 & 89.1 \\
\hline 1660 & 8.72 & 17.65 & - & - & 29.33 & 37.71 & 88.6 \\
\hline 1670 & 8.26 & 16.81 & - & - & 21.99 & 35.75 & 82.3 \\
\hline 1680 & 7.87 & 16.64 & - & 25.85 & 22.53 & 34.51 & 80.1 \\
\hline 1690 & 8.36 & 19.82 & - & 29.63 & 21.96 & 33.82 & 83.0 \\
\hline 1700 & 8.78 & 21.50 & - & 34.52 & 20.82 & 32.46 & 82.8 \\
\hline 1710 & 8.72 & 21.89 & - & 32.99 & 20.54 & 34.55 & 86.2 \\
\hline 1720 & 8.66 & 21.95 & - & 32.09 & 21.79 & 33.33 & 85.5 \\
\hline 1730 & 8.25 & 21.88 & - & 28.10 & 20.15 & 33.17 & 84.2 \\
\hline 1740 & 8.39 & 22.42 & 51.25 & 30.78 & 20.23 & 34.98 & 87.1 \\
\hline 1750 & 8.04 & 22.16 & 43.56 & 26.80 & 21.06 & 38.53 & 91.5 \\
\hline 1760 & 7.76 & 20.77 & 44.02 & 26.95 & 21.18 & 42.70 & 94.8 \\
\hline 1770 & 7.72 & 21.26 & 47.18 & 24.95 & 20.54 & 41.56 & 93.6 \\
\hline 1780 & 7.67 & 20.20 & 53.12 & 21.36 & 21.46 & 42.19 & 93.7 \\
\hline 1790 & 7.99 & 20.17 & 48.46 & 23.53 & 22.71 & 42.99 & 96.2 \\
\hline 1800 & 8.86 & 23.37 & 39.15 & 31.57 & 25.23 & 49.17 & 108.8 \\
\hline 1810 & 10.03 & 23.56 & 38.75 & 40.22 & 30.62 & 57.11 & 122.2 \\
\hline 1820 & 8.99 & 20.72 & 21.54 & 34.29 & 25.51 & 57.29 & 114.0 \\
\hline 1830 & 8.68 & 20.00 & 16.81 & 22.86 & 23.11 & 56.03 & 108.6 \\
\hline 1840 & 7.45 & 15.34 & 11.59 & 18.84 & 20.77 & 56.88 & 100.1 \\
\hline 1850 & 7.29 & 14.13 & 11.25 & 14.44 & 19.70 & 52.77 & 95.0 \\
\hline 1860 & 8.50 & 18.00 & 16.80 & - & 21.81 & 47.84 & 99.9 \\
\hline
\end{tabular}


Table A1 (cont.): Individual Price Indices, 1209-1869

\begin{tabular}{|c|c|c|c|c|c|c|c|}
\hline Decade & $\begin{array}{l}\text { Tobacco } \\
\text { (d./1b) }\end{array}$ & $\begin{array}{l}\text { Books } \\
\text { (s./ } \\
\text { book) }\end{array}$ & $\begin{array}{l}\text { Silver } \\
\text { (d./oz) }\end{array}$ & $\begin{array}{l}\text { Pewter } \\
\text { (d./1b) }\end{array}$ & $\begin{array}{l}\text { Brass } \\
\text { Goods } \\
\text { (d./1b ) }\end{array}$ & $\begin{array}{l}\text { Woodwares } \\
\text { (index) }\end{array}$ & $\begin{array}{l}\text { Pottery } \\
\text { (d./plate) }\end{array}$ \\
\hline & & & & & & & \\
\hline 1200 & - & - & 23.8 & - & - & - & - \\
\hline 1210 & - & - & 23.8 & - & - & - & - \\
\hline 1220 & - & - & 23.8 & 1.85 & - & - & - \\
\hline 1230 & - & - & 23.8 & - & - & - & - \\
\hline 1240 & - & - & 23.8 & - & - & - & - \\
\hline 1250 & - & - & 23.8 & - & - & - & - \\
\hline 1260 & - & - & 23.8 & 1.79 & - & - & - \\
\hline 1270 & - & - & 23.8 & 1.70 & 2.50 & - & - \\
\hline 1280 & - & - & 23.9 & 2.31 & 2.29 & - & - \\
\hline 1290 & - & - & 23.9 & 2.17 & 2.28 & - & - \\
\hline 1300 & - & - & 23.9 & 2.20 & 2.00 & - & - \\
\hline 1310 & - & - & 23.9 & 2.89 & 3.00 & - & - \\
\hline 1320 & - & - & 23.9 & 2.64 & 2.53 & - & - \\
\hline 1330 & - & - & 24.3 & 2.64 & 3.05 & - & - \\
\hline 1340 & - & - & 25.6 & 2.51 & 2.46 & - & - \\
\hline 1350 & - & - & 29.2 & 3.34 & 2.87 & - & - \\
\hline 1360 & - & - & 29.5 & 3.55 & 3.01 & - & - \\
\hline 1370 & - & - & 29.5 & 3.48 & 3.43 & - & - \\
\hline 1380 & - & - & 29.5 & 3.43 & 3.84 & - & - \\
\hline 1390 & - & - & 29.5 & 3.18 & 3.77 & - & - \\
\hline 1400 & - & - & 29.5 & 3.47 & 3.93 & - & - \\
\hline 1410 & - & - & 34.2 & 3.30 & 3.61 & - & - \\
\hline 1420 & - & - & 35.4 & 2.87 & 3.00 & - & - \\
\hline 1430 & - & - & 35.4 & 2.75 & 3.10 & - & - \\
\hline 1440 & - & - & 35.4 & 3.12 & 4.02 & - & - \\
\hline 1450 & - & - & 35.4 & 3.12 & 3.46 & - & - \\
\hline 1460 & - & - & 39.8 & 3.17 & 3.79 & - & - \\
\hline 1470 & - & - & 44.3 & 3.69 & 3.99 & - & - \\
\hline 1480 & - & - & 44.3 & 3.58 & 3.19 & - & - \\
\hline 1490 & - & - & 44.3 & 3.88 & 4.13 & - & - \\
\hline 1500 & - & - & 44.3 & 4.24 & 3.87 & - & - \\
\hline 1510 & - & - & 44.3 & 5.13 & 4.06 & - & - \\
\hline 1520 & - & - & 47.6 & 4.97 & 3.74 & - & - \\
\hline 1530 & - & - & 49.8 & 4.87 & 3.61 & - & - \\
\hline 1540 & - & - & 52.5 & 5.26 & 4.51 & - & - \\
\hline
\end{tabular}


Table A1 (cont.): Individual Price Indices, 1209-1869

\begin{tabular}{|c|c|c|c|c|c|c|c|}
\hline Decade & $\begin{array}{l}\text { Tobacco } \\
\text { (d./lb) }\end{array}$ & $\begin{array}{l}\text { Books } \\
\text { (s./book) }\end{array}$ & $\begin{array}{l}\text { Silver } \\
\text { (d./oz) }\end{array}$ & $\begin{array}{l}\text { Pewter } \\
\text { (d./1b) }\end{array}$ & $\begin{array}{l}\text { Brass } \\
\text { Goods } \\
(\mathrm{d} . / 1 \mathrm{~b})\end{array}$ & $\begin{array}{l}\text { Woodw } \\
\text { ares } \\
\text { (index) }\end{array}$ & $\begin{array}{l}\text { Pottery } \\
\text { (d./plate) }\end{array}$ \\
\hline 1550 & - & - & 63.8 & 8.21 & 5.14 & - & - \\
\hline 1560 & - & - & 66.4 & 8.64 & 7.28 & - & - \\
\hline 1570 & - & - & 66.4 & 7.68 & 7.23 & - & - \\
\hline 1580 & - & - & 66.4 & 7.57 & 6.42 & - & - \\
\hline 1590 & - & - & 66.4 & 8.20 & 7.48 & - & - \\
\hline 1600 & - & - & 68.4 & 9.52 & 8.32 & - & - \\
\hline 1610 & - & - & 68.6 & 10.84 & 10.46 & - & - \\
\hline 1620 & - & - & 68.6 & 11.60 & 11.94 & - & - \\
\hline 1630 & - & - & 68.6 & 13.62 & 13.32 & - & - \\
\hline 1640 & - & - & 68.6 & 14.70 & 11.17 & - & - \\
\hline 1650 & - & - & 68.6 & 14.22 & 11.58 & - & - \\
\hline 1660 & - & - & 68.6 & 13.81 & 11.64 & - & - \\
\hline 1670 & - & - & 68.6 & 13.40 & 11.64 & - & - \\
\hline 1680 & - & - & 68.6 & 12.24 & 11.00 & - & - \\
\hline 1690 & - & 6.43 & 69.0 & 12.06 & 11.21 & - & - \\
\hline 1700 & - & 4.30 & 68.3 & 12.61 & 12.95 & - & - \\
\hline 1710 & - & 4.50 & 68.9 & 12.35 & 11.57 & - & - \\
\hline 1720 & - & 10.82 & 69.5 & 12.19 & 13.68 & - & - \\
\hline 1730 & - & 5.84 & 69.2 & 12.42 & 11.29 & - & - \\
\hline 1740 & 13.5 & 6.05 & 69.1 & 11.89 & 10.98 & 48.5 & 2.08 \\
\hline 1750 & 13.0 & 7.02 & 70.9 & 12.36 & 11.02 & 56.9 & - \\
\hline 1760 & 14.8 & 7.39 & 71.6 & 11.48 & 9.39 & 61.8 & 3.05 \\
\hline 1770 & 21.5 & 7.58 & 70.8 & 12.38 & 9.38 & 65.1 & 3.51 \\
\hline 1780 & 34.2 & - & 70.2 & 11.57 & - & 65.0 & 2.86 \\
\hline 1790 & 36.9 & 9.66 & 68.0 & 13.58 & 9.69 & 81.7 & 4.52 \\
\hline 1800 & 46.7 & 13.97 & 74.5 & 16.31 & 5.92 & 96.0 & 4.11 \\
\hline 1810 & 56.8 & 14.52 & 76.4 & 18.25 & 15.59 & 128.3 & 4.89 \\
\hline 1820 & 56.9 & 15.14 & 64.5 & 18.35 & 13.16 & 115.6 & 5.17 \\
\hline 1830 & 50.0 & 14.62 & 64.3 & 15.58 & 11.85 & 111.3 & 4.94 \\
\hline 1840 & 48.8 & 13.25 & 64.4 & 11.42 & 9.87 & 122.2 & 3.43 \\
\hline 1850 & 52.1 & 12.26 & 66.2 & 14.42 & 9.09 & 112.8 & 5.28 \\
\hline 1860 & 52.6 & 12.38 & 66.0 & - & 11.96 & 100.0 & 6.45 \\
\hline
\end{tabular}


Table A1 (cont.): Individual Price Indices, 1209-1869

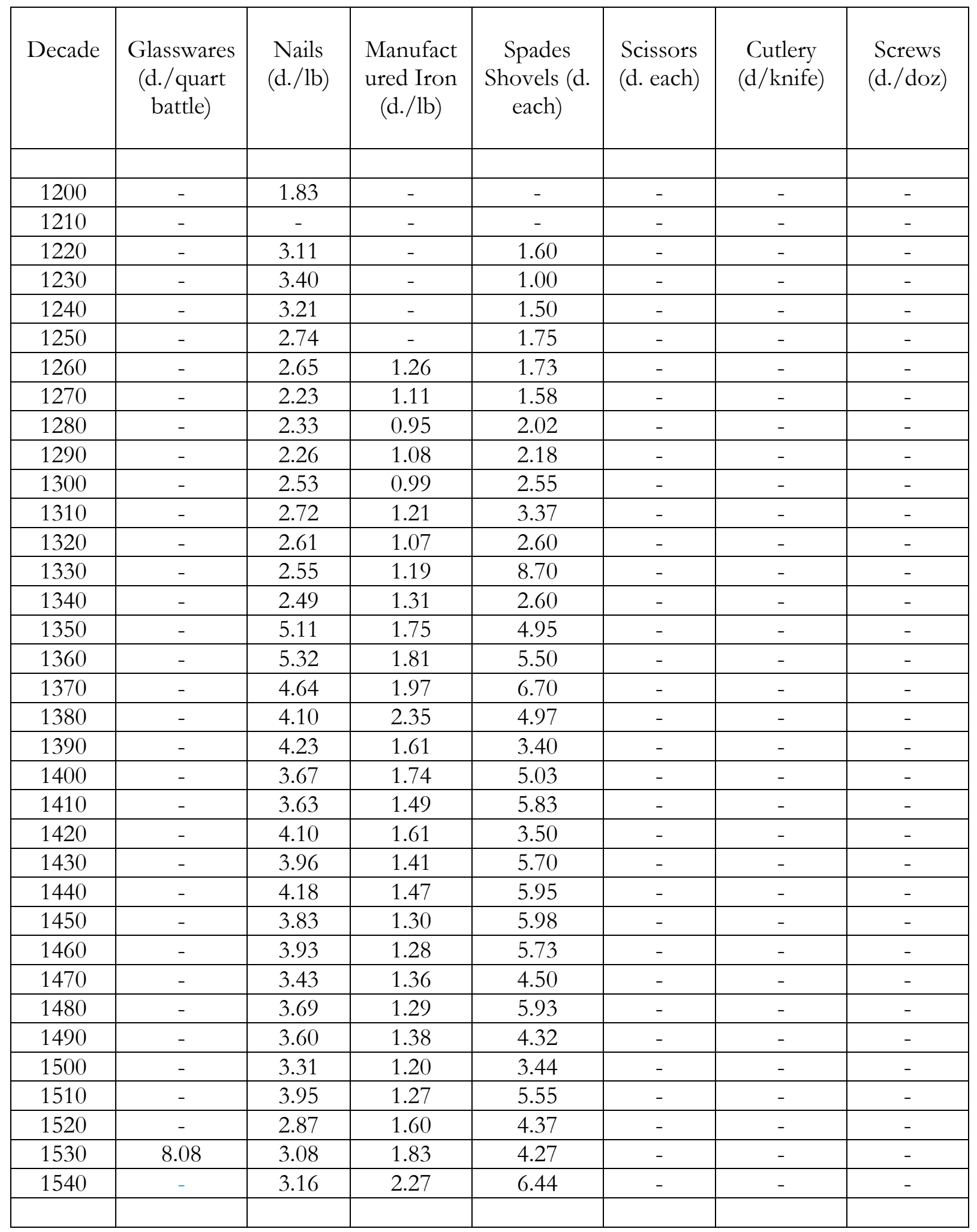


Table A1 (cont.): Individual Price Indices, 1209-1869

\begin{tabular}{|c|c|c|c|c|c|c|c|}
\hline Decade & $\begin{array}{c}\text { Glasswares } \\
\text { (d./quart } \\
\text { battle) }\end{array}$ & $\begin{array}{l}\text { Nails } \\
\text { (d./lb) }\end{array}$ & $\begin{array}{l}\text { Manufact } \\
\text { ured Iron } \\
\text { (d./lb) }\end{array}$ & $\begin{array}{c}\text { Spades } \\
\text { Shovels (d. } \\
\text { each) }\end{array}$ & $\begin{array}{l}\text { Scissors } \\
\text { (d. each) }\end{array}$ & $\begin{array}{c}\text { Cutlery } \\
\text { (d/knife) }\end{array}$ & $\begin{array}{l}\text { Screws } \\
\text { (d./doz) }\end{array}$ \\
\hline 1550 & - & 3.98 & 2.79 & 9.07 & - & - & - \\
\hline 1560 & - & 4.37 & 2.90 & 9.14 & - & - & - \\
\hline 1570 & 7.00 & 4.56 & 2.87 & 11.89 & - & - & - \\
\hline 1580 & 4.94 & 5.02 & 3.14 & 8.06 & - & - & - \\
\hline 1590 & 2.62 & 4.77 & 3.31 & 8.67 & - & - & - \\
\hline 1600 & 2.62 & 4.49 & 4.38 & 12.92 & - & - & - \\
\hline 1610 & 1.56 & 4.71 & 4.52 & 14.36 & - & - & - \\
\hline 1620 & 3.86 & 4.13 & 4.27 & 17.87 & - & - & - \\
\hline 1630 & 7.09 & 4.62 & 4.59 & 21.08 & & & - \\
\hline 1640 & - & 4.58 & 4.86 & 15.80 & - & - & - \\
\hline 1650 & - & 5.12 & 4.52 & 22.33 & - & - & - \\
\hline 1660 & 6.36 & 4.12 & 4.46 & 17.73 & - & - & - \\
\hline 1670 & 4.45 & 4.40 & 4.28 & 21.33 & & & - \\
\hline 1680 & 3.87 & 4.84 & 3.84 & 15.72 & - & - & - \\
\hline 1690 & 4.88 & 3.92 & 4.10 & 19.60 & - & - & - \\
\hline 1700 & 3.11 & 4.40 & 4.34 & 21.68 & - & - & - \\
\hline 1710 & - & 3.81 & 4.16 & 30.83 & - & - & - \\
\hline 1720 & 2.51 & 4.14 & 3.83 & 26.00 & - & - & - \\
\hline 1730 & 2.50 & 3.96 & 3.95 & 36.24 & - & - & - \\
\hline 1740 & 2.84 & 3.76 & 3.50 & 26.03 & - & 4.20 & 6.89 \\
\hline 1750 & 2.90 & 3.45 & 3.36 & 27.87 & - & - & - \\
\hline 1760 & 3.79 & 3.80 & 3.83 & 37.03 & 15.36 & 4.01 & 6.00 \\
\hline 1770 & 3.70 & 3.98 & 3.76 & 27.37 & 14.81 & 4.30 & 5.47 \\
\hline 1780 & 7.11 & 3.79 & 3.83 & 37.40 & 17.57 & 5.95 & 4.81 \\
\hline 1790 & 2.81 & 4.36 & 4.59 & 54.70 & 16.56 & 6.40 & 7.68 \\
\hline 1800 & 3.23 & 5.05 & 5.05 & 51.43 & 12.26 & 9.16 & 8.04 \\
\hline 1810 & 3.83 & 5.71 & 4.67 & 48.35 & 26.20 & 9.29 & 7.37 \\
\hline 1820 & 4.28 & 3.77 & 3.37 & 41.16 & 22.04 & 8.33 & 8.50 \\
\hline 1830 & 4.57 & 4.33 & 2.92 & 36.26 & 27.04 & 8.29 & 8.03 \\
\hline 1840 & 2.60 & 3.66 & 2.25 & 35.66 & 21.48 & 8.68 & 5.06 \\
\hline 1850 & 2.85 & 3.19 & 2.54 & 30.65 & 27.02 & 9.19 & 4.08 \\
\hline 1860 & 2.80 & 3.72 & 2.23 & 40.83 & 30.00 & 13.35 & 5.58 \\
\hline
\end{tabular}

Table A1 (cont.): Individual Price Indices, 1209-1869 


\begin{tabular}{|c|c|c|c|c|c|c|c|}
\hline Decade & $\begin{array}{l}\text { Rope } \\
\text { (d./lb) }\end{array}$ & $\begin{array}{c}\text { Paper } \\
\text { (d./quire) }\end{array}$ & $\begin{array}{c}\text { Paint } \\
\text { (d./lb) }\end{array}$ & $\begin{array}{c}\text { Manufact } \\
\text { ured } \\
\text { Goods } \\
\text { (Index) }\end{array}$ & $\begin{array}{l}\text { Bricks } \\
\text { (s./100) }\end{array}$ & $\begin{array}{l}\text { Timber } \\
\left(\mathrm{d} . / \mathrm{ft}^{3}\right)\end{array}$ & $\begin{array}{c}\text { Window } \\
\text { Glass } \\
\left(\mathrm{d} / \mathrm{ft}^{2}\right)\end{array}$ \\
\hline & & & & & & & \\
\hline 1200 & - & - & - & - & - & - & - \\
\hline 1210 & - & - & - & - & - & - & - \\
\hline 1220 & - & - & - & 17.7 & - & - & - \\
\hline 1230 & - & - & - & - & - & - & - \\
\hline 1240 & - & - & - & 19.6 & - & - & - \\
\hline 1250 & - & - & - & 19.4 & - & - & - \\
\hline 1260 & - & - & - & 19.0 & - & - & - \\
\hline 1270 & - & - & 2.65 & 17.5 & - & - & - \\
\hline 1280 & - & - & 3.52 & 18.5 & 4.24 & - & - \\
\hline 1290 & 1.110 & - & 2.31 & 18.8 & 4.53 & - & - \\
\hline 1300 & 0.490 & - & 3.08 & 19.3 & 4.82 & - & 4.97 \\
\hline 1310 & 0.950 & - & 3.42 & 23.2 & 4.38 & - & 7.32 \\
\hline 1320 & 0.660 & - & 3.92 & 21.3 & 3.62 & - & 4.17 \\
\hline 1330 & 0.850 & - & 4.75 & 24.4 & 3.88 & - & - \\
\hline 1340 & 0.500 & - & 2.48 & 21.5 & 3.83 & - & 2.53 \\
\hline 1350 & 0.985 & 7.97 & 4.23 & 30.3 & 6.82 & - & - \\
\hline 1360 & 1.663 & 10.26 & 2.81 & 34.3 & 8.57 & - & 13.00 \\
\hline 1370 & 1.375 & 9.71 & 5.03 & 34.9 & 7.92 & - & - \\
\hline 1380 & 1.875 & - & 4.93 & 33.0 & 7.26 & - & 8.00 \\
\hline 1390 & - & 7.44 & 4.64 & 30.9 & 7.97 & - & 9.00 \\
\hline 1400 & 1.700 & 6.75 & - & 32.1 & 9.00 & - & 11.00 \\
\hline 1410 & 1.363 & 5.58 & - & 31.1 & 8.15 & - & 9.38 \\
\hline 1420 & 1.536 & 4.92 & 10.54 & 29.7 & 9.57 & - & 8.00 \\
\hline 1430 & 1.420 & 4.61 & - & 29.8 & 8.36 & - & 9.63 \\
\hline 1440 & 1.413 & 4.26 & - & 31.7 & 9.04 & 1.53 & 10.00 \\
\hline 1450 & 1.500 & 4.38 & 1.55 & 30.6 & 8.45 & 1.80 & 6.05 \\
\hline 1460 & 1.556 & 3.92 & 1.38 & 30.9 & 7.60 & 0.53 & 6.75 \\
\hline 1470 & 1.293 & 4.41 & - & 30.6 & 7.03 & 1.82 & 4.39 \\
\hline 1480 & 1.260 & 4.10 & 3.49 & 30.4 & 7.43 & 1.83 & 6.33 \\
\hline 1490 & 1.276 & 3.69 & 3.75 & 30.1 & 7.93 & 1.81 & - \\
\hline 1500 & 1.160 & 3.52 & 3.10 & 28.3 & 7.91 & 1.43 & 6.31 \\
\hline 1510 & 1.262 & 3.43 & 4.70 & 31.6 & 7.91 & 1.55 & 4.61 \\
\hline 1520 & 1.447 & 3.75 & 6.25 & 31.5 & 7.66 & 1.28 & 4.96 \\
\hline 1530 & 1.753 & 3.55 & 4.08 & 33.4 & 7.39 & 1.73 & 4.46 \\
\hline 1540 & 1.596 & 4.17 & & 38.1 & 9.04 & 1.92 & 4.51 \\
\hline
\end{tabular}


Table A1 (cont.): Individual Price Indices, 1209-1869

\begin{tabular}{|c|c|c|c|c|c|c|c|}
\hline Decade & $\begin{array}{l}\text { Rope } \\
\text { (d./lb) }\end{array}$ & $\begin{array}{c}\text { Paper } \\
\text { (d./quire) }\end{array}$ & $\begin{array}{l}\text { Paint } \\
\text { (d./lb) }\end{array}$ & $\begin{array}{c}\text { Manufac } \\
\text { tured } \\
\text { Goods } \\
\text { (Index) }\end{array}$ & $\begin{array}{l}\text { Bricks } \\
\text { (s./100) }\end{array}$ & $\begin{array}{l}\text { Timber } \\
\left(\mathrm{d} . / \mathrm{ft}^{3}\right)\end{array}$ & $\begin{array}{l}\text { Window } \\
\text { Glass } \\
\left(\mathrm{d} / \mathrm{ft}^{2}\right)\end{array}$ \\
\hline & & & & & & & \\
\hline 1550 & 3.412 & 5.36 & 2.73 & 51.6 & 10.98 & 2.97 & 6.92 \\
\hline 1560 & 3.671 & 5.98 & 4.01 & 56.7 & 17.46 & 3.02 & 6.64 \\
\hline 1570 & 3.156 & 6.25 & 6.78 & 57.9 & 17.43 & 3.17 & 6.50 \\
\hline 1580 & 2.804 & 5.74 & 1.86 & 53.9 & 15.57 & 2.85 & 6.34 \\
\hline 1590 & 3.224 & 5.67 & - & 56.2 & 15.60 & 3.18 & 5.96 \\
\hline 1600 & 3.337 & 6.02 & 9.09 & 63.4 & 16.31 & 4.65 & 5.84 \\
\hline 1610 & 4.103 & 5.84 & 10.53 & 69.1 & 17.27 & 6.45 & 5.83 \\
\hline 1620 & 4.494 & 6.59 & 6.50 & 73.4 & 16.76 & 6.50 & 5.07 \\
\hline 1630 & 6.407 & 6.47 & 6.08 & 84.0 & 17.33 & 7.37 & 5.52 \\
\hline 1640 & 5.734 & 7.78 & 5.42 & 81.0 & 17.89 & 8.04 & 6.30 \\
\hline 1650 & 6.437 & 11.11 & 6.97 & 89.0 & 22.92 & 8.73 & 6.42 \\
\hline 1660 & 7.320 & 12.07 & - & 86.6 & 23.76 & 10.72 & 5.78 \\
\hline 1670 & 7.645 & 7.91 & - & 83.3 & 22.41 & 9.59 & 5.32 \\
\hline 1680 & 7.166 & 9.40 & 6.24 & 77.9 & 23.89 & 10.67 & 6.60 \\
\hline 1690 & 7.371 & 13.47 & 3.34 & 83.3 & 22.77 & 10.15 & 6.91 \\
\hline 1700 & 6.208 & 13.07 & 6.41 & 83.3 & 22.27 & 10.00 & 6.55 \\
\hline 1710 & 6.765 & 13.36 & 16.30 & 83.7 & 24.61 & 9.51 & 6.11 \\
\hline 1720 & 7.476 & 12.89 & 21.17 & 85.1 & 26.36 & 8.81 & 6.53 \\
\hline 1730 & 6.833 & 12.88 & - & 82.4 & 23.27 & 7.95 & 5.88 \\
\hline 1740 & 5.973 & 13.45 & 3.18 & 77.6 & 28.00 & 7.76 & 6.11 \\
\hline 1750 & 6.767 & 10.35 & 6.63 & 77.0 & 26.15 & 8.88 & 8.30 \\
\hline 1760 & 6.073 & 11.13 & 6.04 & 80.1 & 28.86 & 9.34 & 7.43 \\
\hline 1770 & 6.784 & 10.48 & 3.53 & 78.3 & 28.72 & 9.91 & 10.01 \\
\hline 1780 & 8.082 & 11.84 & 5.45 & 87.1 & 31.99 & 9.63 & 12.70 \\
\hline 1790 & 9.077 & 12.67 & 5.43 & 96.4 & 44.35 & 12.98 & 10.18 \\
\hline 1800 & 11.315 & 19.95 & 8.68 & 106.1 & 60.94 & 22.17 & 14.21 \\
\hline 1810 & 19.020 & 21.81 & 13.00 & 128.6 & 68.88 & 25.31 & 17.42 \\
\hline 1820 & 15.020 & 22.59 & 6.84 & 114.4 & 64.10 & 17.11 & 19.89 \\
\hline 1830 & 5.780 & 19.91 & 4.06 & 102.9 & 58.26 & 15.53 & 17.32 \\
\hline 1840 & 12.000 & 16.59 & 4.37 & 87.6 & 53.44 & 12.42 & 14.40 \\
\hline 1850 & 8.095 & 14.35 & 3.93 & 88.9 & 45.62 & 9.07 & 7.66 \\
\hline 1860 & 9.510 & 12.14 & 5.05 & 100.0 & 48.35 & 9.43 & 11.90 \\
\hline
\end{tabular}

